\title{
Controlling of dairy cattle breeding programs
}

\author{
Dissertation \\ to obtain the Doctoral Degree \\ at the Faculty of Agricultural Sciences, \\ Georg-August-University Göttingen
}

presented by

Sven Schierenbeck

born in Bremen

Göttingen, July 2010 
D7

1. Referee: Prof. Dr. Henner Simianer

Professor of Animal Breeding and Genetics

Department of Animal Sciences

Georg-August-University, Göttingen

2. Co-referee: Prof. Dr. Hermann H. Swalve

Professor of Animal Breeding

Institute of Agricultural and Nutritional Sciences

Martin-Luther-University, Halle

Date of disputation: 29th June 2010 


\section{Acknowlegdements}

I would like to thank:

Prof. Dr. Henner Simianer for giving me the opportunity to work on this interesting topic, working as the main supervisor and accepting this thesis.

Prof. Dr. H.H. Swalve for taking over the co-reference and for accepting this thesis.

PD Dr. Sven König for always supporting me whenever problems appeared.

Lower Saxon Ministry of Food, Agriculture, Consumer Protection and Regional Development for financial support of this project.

Dr. Otto-Werner Marquardt and Dr. Dettmar Frese of Masterrind $\mathrm{GmbH}$, Verden as well as Friedrich Reinhardt and Dr. Reinhard Reents of vit w.V., Verden for supporting me with practical advices and providing vast amounts of data.

Bianca Lind, Tamina Pinent, Kerstin Brügemann and Pia Rehbein for sharing the office with me, all the helpful advices and fruitful discussions.

Florian Sitzenstock and Tim Koch and Christine Sanker for all the interesting talks, relaxation and sometimes distraction from the day-to-day work.

All colleagues from the former institute and especially those from the Animal Breeding and Genetics Group for help and a warm working environment.

Christina Schmitz for her friendship and for always encouraging me to hold on.

My parents Annelie and Hermann for their unbelievable support and love and for giving me all I needed to get here.

Anna for all the love, patience, tolerance, and motivation. You are enriching my life. 


\section{Table of Contents}

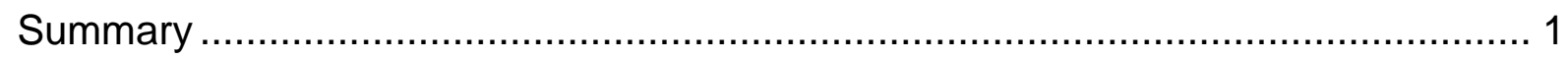

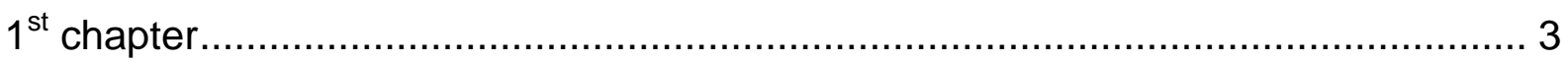

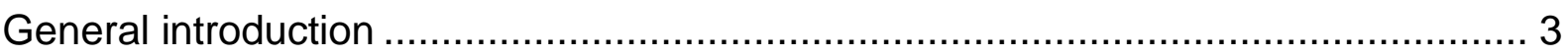

Economic success and controlling of dairy cattle breeding programs .................... 4

Influences on auction prices for dairy cattle .................................................. 6

Contract herds in dairy cattle breeding ....................................................... 7

Impact of inbreeding and management of genetic variability in dairy populations.. 9

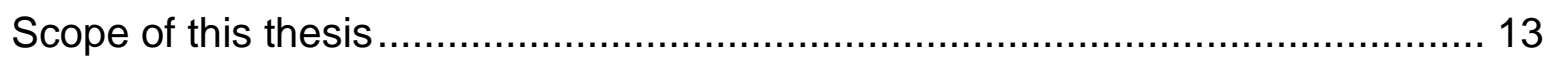

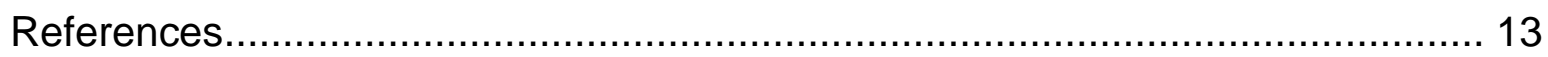

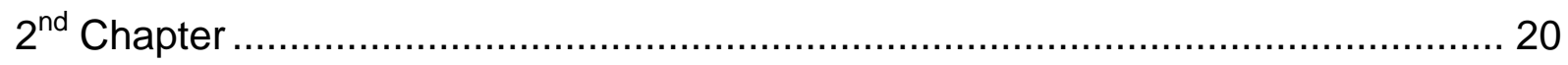

Genetic and Environmental Impact on Auction Prices for Holstein Cows ................ 20

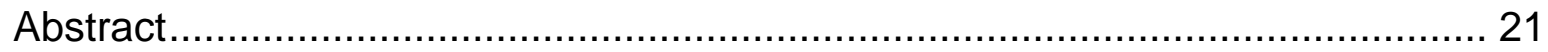

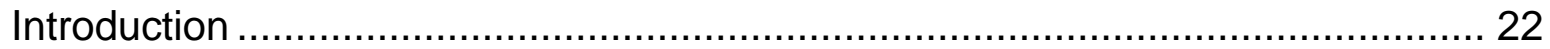

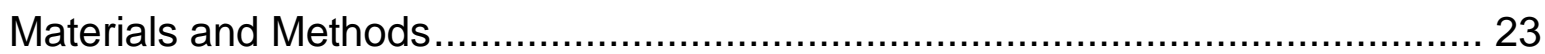

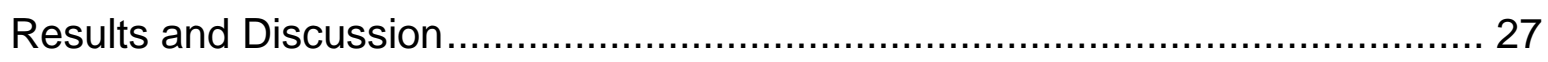

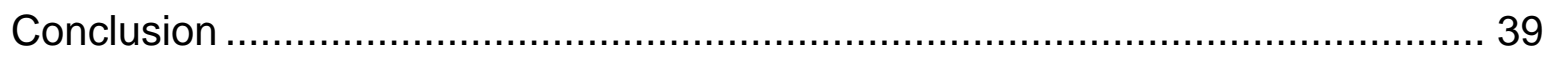

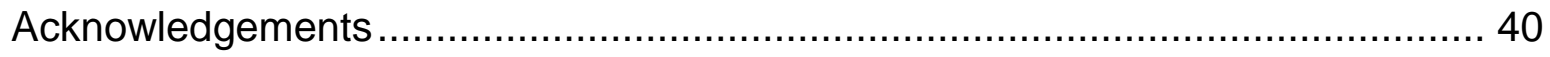

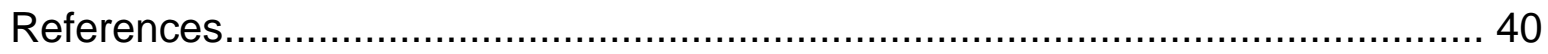

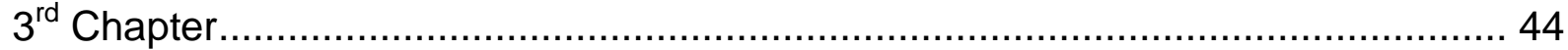

Identification of Informative Cooperator Herds for Progeny Testing Based on Yield

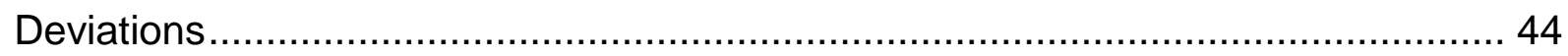

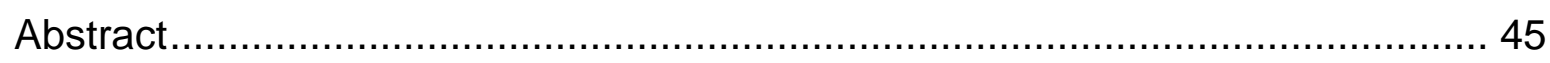

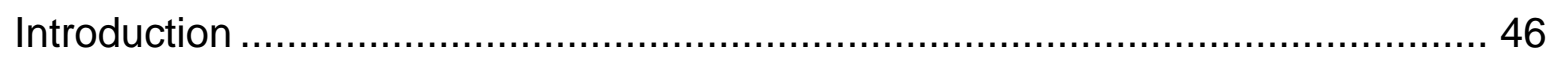

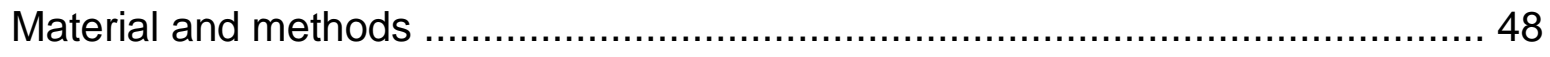

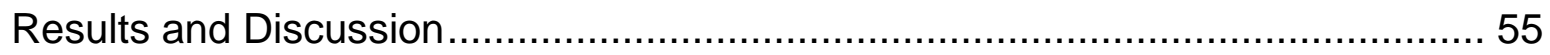

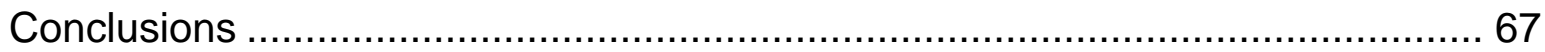

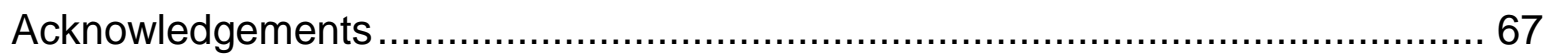

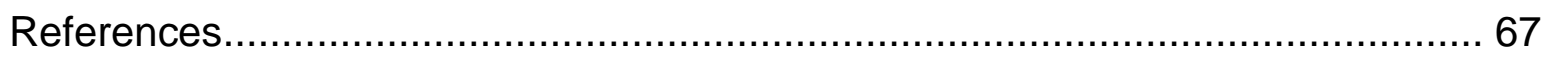


$4^{\text {th }}$ Chapter...

Controlling Inbreeding and Maximizing Genetic Gain using Semi-definite

Programming with Pedigree Based and Genomic Relationships. 73

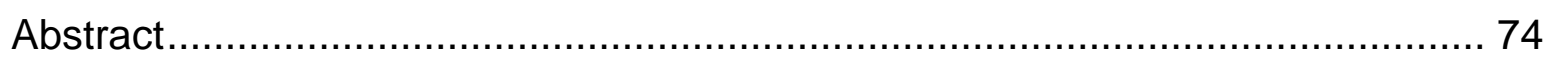

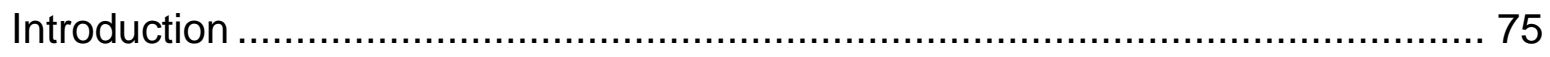

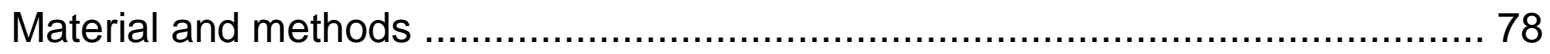

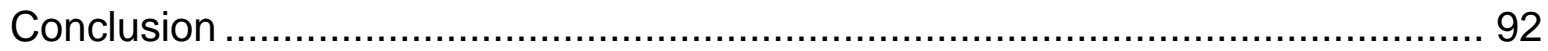

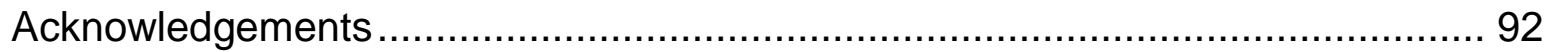

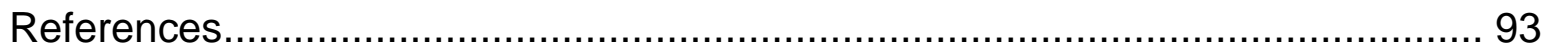




\section{Summary}

The overall goal of this study was to develop possible controlling approaches for dairy cattle breeding programs. For this reason different topics from practical dairy cattle breeding were studied. Initially, genetic and environmental impact factors on auction prices of first lactation Holstein cows were analysed. Subsequently, a possible selection strategy for informative cooperator herds in progeny test programs was developed and its impact on a breeding program for Holstein cows was studied. Finally, an approach for the management of genetic variability in dairy cattle populations was applied to a set of preselected potential bull dams and sires, using additive genetic and genomic relationships.

For the first study the impact of a variety of traits and effects on auction prices was determined. Data of 1565 cows in first parity were collected at six monthly auction sales and scored by two classifiers in the auction hall. The analysis of variance revealed a highly significant impact of auction date, test day milk yield, stage of lactation, origin of sire, and miscellaneous defects on auction prices. The feet and leg, udder, and body composite also had a significant effect on the price with higher scores being associated with higher prices. Economic weights for type traits were derived by utilizing results from regression analysis. Highest economic weights per genetic standard deviation for linearly scored type traits were rear udder height, front teat placement, and strength. Genetic parameters for linear type traits scored at the auction date were consistent with literature reports. Heritability for the auction price was 0.27 , and the auction price was genetically positively correlated to the feet and leg, udder, and body composite. Moreover, a relative breeding value for auction price was estimated for 27 influential sires, and correlated with official indices for production, conformation, somatic cell count, functional herd life, fertility, and total net merit index.

The second objective of this study was to identify informative cooperator herds. An approach based on yield deviations (YD) was used to identify those herds providing the highest content of information in terms of genetic differentiation. The overall YD of 717,377 first lactation cows from two 
regions in East and West Germany were used. Daughters were ranked and classified within sire either for protein yield, fat yield, milk yield or somatic cell score (SCS) by extremeness of their YD. A pronounced genetic differentiation in protein yield was associated with high quality herd management characteristics. The same methodology applied for YD in SCS suggested a distinct genetic differentiation in SCS for cows in those herds characterized by a relatively high value for average somatic cell count. Ranks of herd calving years $(\mathrm{HCY})$ and ranks of herds were calculated by averaging YD percentages within $\mathrm{HCY}$, and within herds, respectively. A further partitioning of ranks of herds into quartiles, combined with an association study for descriptive herd parameters revealed that herds belonging to the first quartile had the highest average protein yield, the highest intra-herd standard deviation for the national production index, and the lowest age at first calving. Correlations between daughter yield deviations for the highest and the lowest herd quartile did not support the existence of genotype by environment interaction between test and production environment.

The third part of this thesis addresses the management of genetic variability in dairy cattle breeding. An algorithm using semi-definite programming was either combined with pedigree $\left(a_{i j}\right)$ or genomic relationships $\left(f_{i j}\right)$ among selection candidates. Selection candidates were 484 genotyped bulls and 499 pre-selected genotyped bull dams passing a central test on station. In different scenarios, separately for production index (RZM) and somatic cell score index (RZS), constraints on the average pedigree relationships among future progeny were applied. Despite the difference for some bulls in genomic and pedigree relationships, similar trends for results in genetic gain and achieved coefficients of relationships were observed for constraints on pedigree and corresponding genomic relationships. Generally, allowing higher values for relationships resulted in an increase of genetic gain for RZM and RZS, as well as in the number of selected sires. More sires were selected for all scenarios when restricting genomic relationships, compared to restrictions on pedigree relationships. Furthermore a simulated annealing algorithm was applied to minimize relationships in the subsequent generation. 
$1^{\text {st }}$ chapter

\section{General introduction}




\section{Economic success and controlling of dairy cattle breeding programs}

The implementation of breeding programs based on progeny testing as suggested by Henderson (1964) and Skjervold and Langholz (1964) still has a strong influence on the structure of today's dairy cattle breeding programs. Since its implementation conventional progeny testing has resulted in a substantial genetic progress especially in production traits (e.g.Van Tassell and Van Vleck, 1991, Swalve and Höver, 2003)

For a long time the objective of German breeding programs was not to maximize financial profit, but the optimization of productive efficiency of the dairy population in a specific region. Thus genetic gain was the critical success factor scientific studies focussed on (Grandke, 2002). Increasing economic pressure due to the globalization of Holstein breeding (Dekkers et al., 1996, Miglior et al., 2005) and decreasing governmental financial support increasingly forced breeding programs to consider economic issues in the last two decades.

Grandke and Simianer (1998) compared several German Holstein breeding programs with regard to efficiency. As a measure of success they used the share of bulls within the list of the top 50 ranked by different selection indices in relation to the amount of herdbook cows. Their results show that population size seemed to be an unsuitable parameter when evaluating the success of artificial insemination (Al) organizations, as significant impact of population size on the amount of top bulls could not be confirmed. Breeding programs with medium populations of 50,000 to 100,000 cows had the lowest success rates whereas rather small breeding programs tended to have the highest. A study conducted by Swalve and Höver (2003) comparing genetic trend in four regions of Northern and Eastern Germany also revealed no interrelations between population size and increase in genetic gain. Moreover, an analysis of the use of proven sires showed a very large proportion of bulls getting second crop daughters although often used in a very limited way (Swalve and Höver, 2003). This indeed has a positive influence on genetic variability, but indicates reserves in terms of genetic gain achieved by the use of the best available bulls. 
Dekkers et al. (1996) optimized the number of daughters per tested bull for different parameters like maximum genetic gain, number of marketable bulls and net returns from semen sales. The optimal progeny group size for the critical objective, net returns from semen sales, subtracting costs of sampling bulls, was between 95 and 105 daughters. The returns of a breeding program are mainly determined by both the market share and the semen price (Miller, 1988) with market share being the major factor for a long time, as Al companies were unable to develop differentiated products justifying price differences to other companies (Funk, 2006). This has slightly changed with the introduction of new value added products like sexed semen which can also help to reduce breeding costs as a smaller test capacity is needed (Weigel, 2004). Dekkers and Shook (1990) developed methods to quantify returns from breeding programs for a market with complete competition and purchasing decisions of dairy farmers being only based on estimated breeding values (EBV). Market share in such markets is determined by the number of bulls with an EBV above the marketing threshold, the semen price and the number of semen sold per bull. According to Dekkers and Shook (1990) the three ways to affect the market share are to increase the number of bulls sampled, or the number of daughters per bull, or increase the average genetic merit of bulls being tested. Although these are important influences on the market share it is a rather simplified view, as other factors like the Al companies' quality of marketing or their population size have to be considered. For instance about $60 \%$ of the cows in Germany are inseminated with bulls owned by the member Al organization of the dairy farmer (ADR, 2005). Moreover, Swalve and Höver (2003) observed that the bull selection of German dairy farmers not only depends on their total merit index, but also on management traits like calving ease.

König et al. (2007) established a new controlling parameter which is suitable to verify selection decisions as well as to explain differences between the success of Al organizations. They used national EBV from 1998 to 2006 for bulls from 12 different Al companies to determine differences in expected and realized selection intensities of cow sire selection. The ratio between realized and expected selection intensities was determined as the controlling value. Low controlling values indicated necessary improvements. When 
evaluated according to the national top list, Al organizations with high controlling values were successful in the national competition regardless of population size.

As already pointed out, there often is a discrepancy between maximizing genetic gain and maximizing economic returns of a breeding program. This was also confirmed by Neuner et al. (2006) who found progeny testing of few bulls with 160 daughters per bull to be the scenario with the highest benefit for the Al company. If the focus was on maximizing genetic gain, a daughter number as small as 26 was the optimum. Thus a compromise between both goals should be adapted to the individual situation of the Al company.

Genomic selection as suggested by Meuwissen et al. (2001) will probably also have a serious impact on economic decisions of breeding programs. According to Schaeffer (2006), due to the introduction of genomic selection costs for proving bulls can be reduced by $92 \%$ while simultaneously doubling the genetic gain. König et al. (2009) compared a conventional progeny test program with different scenarios of genomic breeding programs. The evaluation criterion was discounted profit reflecting discounted returns minus discounted costs per cow. All genomic scenarios using at least $20 \%$ young bulls without daughter records were up to 2.59 times superior to the conventional breeding program, mainly due to a lower generation interval and a decrease of cost. However, the economic superiority of genomic selection is based on the complete abdication of progeny testing and the condition that dairy farmers are willing to use those genomic bulls. If genotyping costs substantially decrease in the future a two-pathway selection strategy including the genotyping of large amounts of bull calves as proposed by König and Swalve (2009) might even simplify the design of breeding programs and reduce their costs to a larger extent.

\section{Influences on auction prices for dairy cattle}

Besides income from milk production marketing of breeding cattle is an essential source of income for many German dairy farmers. In the last decade, on average more than 26,000 auction sales of Holstein dairy cattle per year were transacted in Germany (ADR, 2005), and $75 \%$ of all sales were from cows in first parity. To assure economic success on local and 
global markets for dairy cattle it is of outstanding importance for farmers and their breeding organizations to have comprehensive information on which traits are being demanded in which qualities by potential buyers. With this information farmers as well as breeding organizations would be able to increase revenues by selecting on those traits.

So far, there were only a few studies addressing auction prices in the Holstein breed which might be out-dated today (Placke, 1982, Ruff et al., 1983). More recent studies have been conducted for Simmental and BrownSwiss cattle in Austria (Fürst-Waltl et al., 2004) and Germany (Krogmeier et al., 2006). Both studies were focussed on deriving economic weights for conformation traits which have a high impact on current selection decisions (Swalve and Höver, 2003). However, the inclusion of conformation traits in a selection index can cause problems as for the derivation of economic weights direct impact of traits on costs and revenues has to be known (Amer et al., 1994). Thus Fürst-Waltl et al. (2004) and Krogmeier et al. (2006) determined the impact of several type traits on auction prices of heifers and cows using regression analysis. Main results were a substantial impact of udder, conformation, frame, and rump structure on the market price. Today the proportion of conformation data in the national selection index RZG is mainly based on 'political' decisions. Findings about economic weights derived with sophisticated methods could help placing accurate emphasis to conformation traits and thus improving total genetic gain.

\section{Contract herds in dairy cattle breeding}

Al breeding schemes as described by Skjervold and Langholz (1964) including selection of superior cows in a herdbook population, mating them to the best available sires and testing their male progeny by random mating in the whole population have been the most common ways of progeny testing since decades.

Hinks (1978) proposed open nucleus breeding schemes primarily for countries with a poor infrastructure consisting of supplier herds that produce cows for test herds in which milk recording is conducted. After the test most cows return to the supplier herds, whereas the best cows are selected for the breeding nucleus. Nicholas and Smith (1983) combined nucleus breeding 
schemes with the intensive use of embryo transfer in a multiple ovulation and embryo transfer (MOET) program. Main elements were the selection of juvenile animals based on ancestor and sibling information and the use of embryo transfer on these animals which leads to a rigorous decline in generation interval. Both approaches were combined by Swalve (1989) in an intensive test herd program. It comprises the use of special bull dam herds where bull dams are tested intensively and embryo transfer is applied to multiply the best cows. Young bulls are progeny tested in cooperator herds, and in the main population only tested sires are used.

Cooperator herds can help to identify superior sires if herds with optimal environments are selected, since keeping animals in superior environments enables them to express their true genetic potential which leads to a higher accuracy of selection (Hammond, 1947, Van Vleck, 1963). As found in several studies, differences in test environments have been associated with differences in estimated variance components with higher additive genetic variances being prevalent in herds with a higher production level (e.g. Van Vleck, 1963, Hill, 1984, Garrick and Van Vleck, 1987). Several aspects like the optimization of management and feeding strategies (Padilla and Keown, 1990), the milking technology and herd size (Weigel et al., 1993) as well as the skills of herdsmen (Short et al., 1990) were identified as possible reasons for increased intra-herd variances.

Another advantage of cooperator herds would be the implementation of recording functional health like mastitis (Philipsson, 1995, De Haas et al., 2002), claw disorders (König et al., 2005) or reproduction diseases (Zwald et al., 2004). Although too expensive and complicated to implement in the whole population, this recording would lead to a higher genetic gain when compared to selection strategies based on indicator traits.

At present, as conventional breeding programs have to adapt to changes associated with the implementation of genomic selection (Meuwissen et al., 2001) the implementation of a system of contract herds gets even more important. Schaeffer (2006) proposed to estimate SNP effects in special cooperator herds while simultaneously emphasizing the advantages of genomic selection concerning genetic gain in terms of cost reduction. To achieve accuracies for genomic breeding values of 0.75 , as assumed in this 
study, a solid database is essential, especially for functional traits (König and Swalve, 2009, VanRaden et al., 2009). This can only be achieved by the standardized recording of these traits in a sufficient amount of selected herds.

Testing bulls in special cooperator herds will also provide sufficient test capacities and reduce costs for logistics, e.g. for type trait classification (Swalve and König, 2007).

Due to the above mentioned arguments and to the increasing economic pressure caused by the higher competition on the semen market (Dekkers et al., 1996) and the decline of governmental subsidies for performance testing several German breeding programs are considering to establish contract herd systems or have already established them. However, until now there are only few sophisticated approaches to select informative contract herds. Some studies have focused on single aspects like the number of usable records (Meinert et al., 1997), or herd size and herd production level (Vierhout et al., 1999). A cluster analysis was suggested by Gernand et al. (2007) to combine favourable effects of large herd size, high production level, and low age at first calving. Brügemann (2008) and Dechow et al. (2008) focussed on genetic analyses and variance component estimation within herds. Brügemann (2008) found increasing additive genetic variances and heritabilities with increasing herd size and improving farm management. In the study by Dechow et al. (2008), intra-herd heritability was additionally negatively correlated with sire misidentification rates. Due to relatively large standard errors of estimates from intra-herd analyses, these approaches are only applicable for very large herds.

\section{Impact of inbreeding and management of genetic variability in dairy populations}

Selection leads to losses of genetic variability and increases of inbreeding rates, associated with negative effects on the sustainability of breeding schemes.

However, due to a considerable genetic progress achieved by intensive selection the rate of inbreeding in dairy populations has risen substantially (e.g. Sorensen et al., 2005, König and Simianer, 2006, Mc Parland et al., 
2007). Mrode et al. (2009) calculated inbreeding coefficients and average relationships in the top 4,000 index in three different countries. Average inbreeding was approximately $2 \%$ in Great Britain and Italy, and $1 \%$ in Ireland. When a joint pedigree was used, inbreeding was slightly higher than $2 \%$. Relationships within the Top 4000 index cows in 2006 from Great Britain, Italy and Ireland were $0.083,0.087$ and 0.107 respectively. Kearney et al. (2004) found an increased rate of inbreeding in UK Holsteins, especially since 1990 when, compared to previous time periods. This was a result of the large influence of a few related sires on the breed. In registered US Holsteins born in 1990 two sires accounted for nearly one quarter of the genes (Young and Seykora, 1996). Moreover several authors found negative associations between production traits and inbreeding. Cassell et al. (2003) observed the summit milk yield in Canadian Holsteins to be decreased by -0.12 to -0.06 $\mathrm{kg} / \mathrm{d}$ per $1 \%$ increase of inbreeding. In Belgian Holsteins inbreeding decreased yield of milk, fat, and protein during a lactation by $19.68,0.96$, and $0.69 \mathrm{~kg}$, respectively, per each $1 \%$ increase in inbreeding in a study conducted by Croquet et al. (2006). Milk production losses per lactation in US Holsteins caused by inbreeding were about $35 \mathrm{~kg}$ per percentage of inbreeding level above 0.01 but increased to $55 \mathrm{~kg}$ per percentage inbreeding level from 0.07 to 0.10 .

Negative consequences associated with inbreeding apart from the loss of genetic variation are an increase of undesirable genetic disorders like complex vertebral malformation (CVM) and inbreeding depression. Several studies have been conducted to study the impact of inbreeding on different traits in dairy populations. For production traits as well as for functional traits a negative impact of inbreeding was found (e.g. Miglior et al., 1995, Wiggans et al., 1995, Wall et al., 2005). Adamec et al. (2006) reported a relatively small increase of stillbirths of 0.25 and $0.20 \%$ for male and female calves per $1 \%$ increase in inbreeding for first parity births. Although effects of inbreeding on stillbirths even declined with increasing parity, effects of inbreeding were consistently unfavourable. In Danish Holsteins Sørensen et al. (2006) found an increase of $1,500 \mathrm{cells} / \mathrm{ml}$ in first lactation cows. Furthermore, comparing a cow with $5 \%$ inbreeding with a cow with $2 \%$ inbreeding, the incidence of mastitis increased by $1.08 \%, 0.55 \%$ and $0.98 \%$ in first, second, and third 
lactation, respectively. These results are in line with Miglior et al. (1995) who reported an effect of 0.012 per percentage inbreeding on linear SCS. However, other studies conducted by Smith et al. (1998), Thompson et al. (2000) and Croquet et al. (2006) found no or very little impact of inbreeding on SCS.

For risk of culling Sewalem et al. (2006) found only a small impact of inbreeding, whereas other studies found fewer day of productive life, higher age at first calving and longer calving intervals (e.g.Smith et al., 1998, Thompson et al., 2000, Adamec et al., 2006). Especially cows with extreme inbreeding coefficients show inbreeding depression. For example GonzálezRecio et al. (2007) observed that cows with an inbreeding coefficient of greater than $25 \%$ had lower pregnancy rates and higher dystocia rates $(-6.37$ and $1.67 \%$, respectively) than low or non-inbred cows.

Meuwissen (1997) developed the optimum genetic contribution selection strategy (OGC) to maintain variability in populations under selection. This method is based on a series of relaxed optimizations using Lagrange Multipliers to maximize genetic progress under the constraint of fixed maximum relationship. Meuwissen and Sonesson (1998) extended this selection rule to overlapping generations and Hinrichs et al. (2006) developed an algorithm enabling the calculation of optimal genetic contribution for large numbers of selection candidates. The optimal genetic contribution theory has been used successfully in many applications (e.g. Kearney et al., 2004, König and Simianer, 2006). König and Simianer (2006) for example applied OGC for elite matings in a breeding program embracing 30 young bulls and found an increase in genetic gain of $13.1 \%$ with the same rate of inbreeding as a conventional breeding program. Moreover, they recommended controlling inbreeding when mating bull sires to bull dams, because these genetic groups have a sustainable impact on the development of genetic relationships in dairy cattle breeding programs. Sonesson and Meuwissen (2000) proposed minimum coancestry matings by applying a simulated annealing algorithm using the results of OGC to minimize inbreeding in a short-term view. 
However, Pong-Wong and Woolliams (2007) showed that the use of Lagrange Multipliers fails to identify a global optimum solution in some cases, as invalid negative genetic contributions could be assigned to some individuals which are consequently fixed to zero and excluded from the set of selection candidates. As an extension Pong-Wong and Woolliams (2007) suggested an algorithm based upon semi-definite programming (SDP) for maximizing genetic gain while restricting inbreeding. They demonstrated that the SDP approach led to substantially higher expected genetic gains in a range of $1.5 \%$ to $9 \%$ when compared to the method of Meuwissen (1997). The SDP approach is also characterized by being able to accommodate any number of constraints (Pong-Wong and Woolliams, 2007) and could even be used to simultaneously constrain both pedigree relationship and also relationship around a QTL under selection (Roughsedge et al., 2008) which might be useful to maintain genetic variation in specific genome regions close to loci under selection.

The use of tools for the management of genetic variability will probably become even more important in the future, as genomic selection, as proposed by Meuwissen et al. (2001), is revolutionizing dairy cattle breeding programs (Hayes et al., 2009). This approach is based on the selection of animals using breeding values estimated on the effects of single nucleotide polymorphisms (SNP). Schaeffer (2006) compared a genomic breeding program with a traditional Canadian breeding program and found a $92 \%$ decrease in breeding costs combined with a substantial increase in genetic gain.

Daetwyler et al. (2007) pointed out that genomic selection will lead to lower inbreeding as amongst others the accuracies of estimated Mendelian sampling terms will be higher which leads to more within family variation and a lower co-selection of sibs. This is in line with the results of several studies that found marker-assisted selection to reduce the rate of pedigree-estimated inbreeding (e.g. Dekkers, 2007, Sonesson, 2007, Pedersen et al., 2009). However, from a practical point of view genomic selection will probably lead to an increased rate of inbreeding per year if not managed correctly. This is due to the fact that high accuracies of estimated breeding values of young animals will probably lead to higher proportions of young animals being 
selected and thus to a shorter generation interval (Hayes et al., 2009). Additionally König et al. (2009) economically evaluated genomic breeding programs and found that gain in discounted profit was strongly correlated with the decrease of selection proportions for young sires having been selected, which will also cause an increase in inbreeding.

\section{Scope of this thesis}

The major scope of this study was to develop possible controlling approaches for dairy cattle breeding programs. For this reason different topics linked to practical dairy cattle breeding were studied. Initially, genetic and environmental impact factors on auction prices of first lactation Holstein cows were analysed in chapter 2 . Subsequently, chapter 3 addresses the issue selection strategy for informative cooperator herds. A selection strategy was developed and its impact on a breeding program for Holsteins was studied. In a last step an approach for the management of genetic variability in dairy cattle populations using genomic relationships was applied to a set of preselected potential bull dams and sires in chapter 4 .

\section{References}

Adamec, V., B. G. Cassell, E. P. Smith, and R. E. Pearson. 2006. Effects of Inbreeding in the Dam on Dystocia and Stillbirths in US Holsteins. Journal of Dairy Science 89:307-314.

ADR. 2005. Annual statistics published by the German Cattle Breeders Federation.

Amer, P. R., G. C. Fox, and C. Smith. 1994. Economic weights from profit equations: appraising their accuracy in the long run. Anim. Prod. 58:11-18.

Brügemann, K. 2008. Untersuchungen zur Heterogenität der Varianzen von

Merkmalen der Milchleistung unter differenzierter Stratifikation des

Gesamtmaterials beim Holsteinrind in Deutschland, Dissertation, University of Halle

Cassell, B. G., V. Adamec, and R. E. Pearson. 2003. Effect of Incomplete Pedigrees on Estimates of Inbreeding and Inbreeding Depression for Days to First Service and Summit Milk Yield in Holsteins and Jerseys. J. Dairy Sci. 86:2967-2976. 
Croquet, C., P. Mayeres, A. Gillon, S. Vanderick, and N. Gengler. 2006. Inbreeding Depression for Global and Partial Economic Indexes, Production, Type, and Functional Traits. J. Dairy Sci. 89:2257-2267.

De Haas, Y., H. W. Barkema, and R. F. Veerkamp. 2002. Genetic parameters of pathogen-specific incidence of clinical mastitis in dairy cows. Anim. Sci. 74:233-242.

Dechow, C. D., H. D. Norman, N. R. Zwald, C. M. Cowan, and O. M. Meland. 2008. Relationship Between Individual Herd-Heritability Estimates and Sire Misidentification Rate. J. Dairy Sci. 91:1640-1647.

Dekkers, J. C. M. 2007. Prediction of response to marker-assisted and genomic selection using selection index theory. Journal of Animal Breeding and Genetics 124:331-341.

Dekkers, J. C. M. and G. E. Shook. 1990. Economic Evaluation of Alternative Breeding Programs for Commercial Artificial Insemination Firms. J. Dairy Sci. 73:1902-1919.

Dekkers, J. C. M., G. E. Vandervoort, and E. B. Burnside. 1996. Optimal Size of Progeny Groups for Progeny-Testing Programs by Artificial Insemination Firms. J. Dairy Sci. 79:2056-2070.

Funk, D. A. 2006. Major Advances in Globalization and Consolidation of the Artificial Insemination Industry. J. Dairy Sci. 89:1362-1368.

Fürst-Waltt, B., J. Wieser, C. Fürst, and J. Sölkner. 2004. Effect of conformation on the auction price of Simmental and Brown Swiss heifers. Züchtungskunde 76:149-161.

Garrick, D. J. and L. D. Van Vleck. 1987. Aspects of Selection for Performance in Several Environments with Heterogeneous Variances. J. Anim Sci. 65:409-421.

Gernand, E., R. Wassmuth, U. U. von Borstel, and S. König. 2007. Heterogeneity of variance components for production traits in large-scale dairy farms. Livest. Sci. 112:78-89.

Grandke, R. 2002. Methoden und Modelle zur strategischen Steuerung von neuzeitlichen Zuchtorganisationen. Habilitationsschrift, University of Göttingen 
Grandke, R. and H. Simianer. 1998. Ein Ansatz zur Quantifizierung von Managementunterschieden zwischen Rinderzuchtprogrammen. Archiv für Tierzucht 41:143-150.

Hammond, J. 1947. Animal breeding in relation to nutrition and environmental conditions. Biol. Rev. 22:195-213.

Hayes, B. J., P. J. Bowman, A. J. Chamberlain, and M. E. Goddard. 2009. Invited review: Genomic selection in dairy cattle: Progress and challenges. J. Dairy Sci. 92:433-443.

Henderson, C. R. 1964. Selecting the Young Sire to Sample in Artificial Insemination. J. Dairy Sci. 47:439-441.

Hill, W. G. 1984. On selection among groups with heterogeneous variance. Anim. Prod. Sci. 39:473-477.

Hinks, C. J. M. 1978. The use of centralized breeding schemes in dairy cattle improvement. Anim. Breed. Abstr. 46.

Hinrichs, D., M. Wetten, and T. H. E. Meuwissen. 2006. An algorithm to compute optimal genetic contributions in selection programs with large numbers of candidates. J. Anim Sci. 84:3212-3218.

Kearney, J. F., E. Wall, B. Villanueva, and M. P. Coffey. 2004. Inbreeding Trends and Application of Optimized Selection in the UK Holstein Population. J. Dairy Sci. 87:3503-3509.

König, S., S. Lessner, and H. Simianer. 2007. Application of Controlling Instruments for Improvements in Cow Sire Selection. J. Dairy Sci. 90:1967-1980.

König, S., A. R. Sharifi, H. Wentrot, D. Landmann, M. Eise, and H. Simianer. 2005. Genetic Parameters of Claw and Foot Disorders Estimated with Logistic Models. J. Dairy Sci. 88:3316-3325.

König, S. and H. Simianer. 2006. Approaches to the management of inbreeding and relationship in the German Holstein dairy cattle population. Livestock Science 103:40-53.

König, S., H. Simianer, and A. Willam. 2009. Economic evaluation of genomic breeding programs. J. Dairy Sci. 92:382-391.

König, S. and H. H. Swalve. 2009. Application of selection index calculations to determine selection strategies in genomic breeding programs. J. Dairy Sci. 92:5292-5303. 
Krogmeier, D., B. Luntz, and K.-U. Götz. 2006. Investigations on the economical value of type traits on the basis of auction sales of first lactation Brown Swiss and Simmental cows. Züchtungskunde 78.

Mc Parland, S. M., J. F. Kearney, M. Rath, and D. P. Berry. 2007. Inbreeding Effects on Milk Production, Calving Performance, Fertility, and Conformation in Irish Holstein-Friesians. J. Dairy Sci. 90:4411-4419.

Meinert, T. R., H. D. Norman, J. M. Mattison, and C. G. Sattler. 1997. Usability for Genetic Evaluations of Records from Herds Participating in Progeny Test Programs of Artificial Insemination Organizations. J. Dairy Sci. 80:2599-2605.

Meuwissen, T. H. 1997. Maximizing the response of selection with a predefined rate of inbreeding. J. Anim Sci. 75:934-940.

Meuwissen, T. H. and A. K. Sonesson. 1998. Maximizing the response of selection with a predefined rate of inbreeding: overlapping generations. J. Anim Sci. 76:2575-2583.

Meuwissen, T. H. E., B. J. Hayes, and M. E. Goddard. 2001. Prediction of Total Genetic Value Using Genome-Wide Dense Marker Maps. Genetics 157:1819-1829.

Miglior, F., E. B. Burnside, and J. C. M. Dekkers. 1995. Nonadditive Genetic Effects and Inbreeding Depression for Somatic Cell Counts of Holstein Cattle. J. Dairy Sci. 78:1168-1173.

Miglior, F., B. L. Muir, and B. J. Van Doormaal. 2005. Selection Indices in Holstein Cattle of Various Countries. J. Dairy Sci. 88:1255-1263.

Miller, P. D. 1988. Implementing Technology for Genetic Improvement: Industry's View. J. Dairy Sci. 71:1967-1971.

Mrode, R., J. F. Kearney, S. Biffani, M. Coffey, and F. Canavesi. 2009. Short communication: Genetic relationships between the Holstein cow populations of three European dairy countries. J. Dairy Sci. 92:5760-5764.

Neuner, S., K.-U. Götz, R. Emmerling, R. Fries, and G. Thaller. 2006. Untersuchungen zur Optimierung der Nachkommenprüfung von Besamungsbullen hinsichtlich der Unternehmensziele einer Besamungsstation. Züchtungskunde 78:257-270. 
Nicholas, F. W. and C. Smith. 1983. Increased rates of genetic change in dairy cattle by embryo transfer and splitting. Animal Production 36:341353.

Padilla, D. and J. F. Keown. 1990. Variances in herd production due to different management practices. J. Anim. Sci. 68 (Suppl. 1):70-71.

Pedersen, L. D., A. C. Sorensen, and P. Berg. 2009. Marker-assisted selection can reduce true as well as pedigree-estimated inbreeding. J. Dairy Sci. 92:2214-2223.

Philipsson, J. 1995. Züchtung auf Gesundheit am Beispiel Skandinavien erfolgreiche Kooperation von Landwirt, Tierarzt, MLP und Zuchtorganisation. Züchtungskunde 67:454-460.

Placke, K.-H. 1982. Untersuchung zur Exterieurbeurteilung in der Schwarzbuntzucht, Dissertation, University of Kiel

Pong-Wong, R. and J. A. Woolliams. 2007. Optimisation of contribution of candidate parents to maximise genetic gain and restricting inbreeding using semidefinite programming (Open Access publication). Genet. Sel. Evol. 39:3-25.

Roughsedge, T., R. Pong-Wong, J. A. Woolliams, and B. Villanueva. 2008. Restricting coancestry and inbreeding at a specific position on the genome by using optimized selection. Genetics Research 90:199-208.

Ruff, N. J., W. E. Vinson, R. E. Pearson, J. M. White, O. M. Meland, and D. P. Edlund. 1983. Factors Affecting Price Differences Within Sales of Registered Holstein Cattle. J. Dairy Sci. 66:587-594.

Schaeffer, L. R. 2006. Strategy for applying genome-wide selection in dairy cattle. J. Anim. Breed. Genet. 123:218-223.

Sewalem, A., G. J. Kistemaker, F. Miglior, and B. J. Van Doormaal. 2006. Analysis of Inbreeding and Its Relationship with Functional Longevity in Canadian Dairy Cattle. J. Dairy Sci. 89:2210-2216.

Short, T. H., R. W. Blake, R. L. Quaas, and L. D. Van Vleck. 1990. Heterogeneous Within-Herd Variance. 1. Genetic Parameters for First and Second Lactation Milk Yields of Grade Holstein Cows. J. Dairy Sci. 73:3312-3320. 
Skjervold, H. and H. J. Langholz. 1964. Factors affecting the optimum structure of Al breeding in dairy cattle. Zeitschr. Tierz. u. Züchtungsbiolol. 80:25-40.

Smith, L. A., B. G. Cassell, and R. E. Pearson. 1998. The Effects of Inbreeding on the Lifetime Performance of Dairy Cattle. J. Dairy Sci. 81:2729-2737.

Sonesson, A. 2007. Within-family marker-assisted selection for aquaculture species. Genetics Selection Evolution 39:301 - 317.

Sonesson, A. K. and T. H. E. Meuwissen. 2000. Mating schemes for optimum contribution selection with constrained rates of inbreeding. Genet. Sel. Evol. 32:231-248.

Sørensen, A. C., P. Madsen, M. K. Sørensen, and P. Berg. 2006. Udder Health Shows Inbreeding Depression in Danish Holsteins. Journal of Dairy Science 89:4077-4082.

Sorensen, A. C., M. K. Sorensen, and P. Berg. 2005. Inbreeding in Danish Dairy Cattle Breeds. J. Dairy Sci. 88:1865-1872.

Swalve, H. H. 1989. Alternative Zuchtprogramme. Was können sie bieten, und wo liegen ihre Grenzen? Tierzüchter 41:59-62.

Swalve, H. H. and K. Höver. 2003. Examinations using the results of breeding value estimation for Holstein sires and cows in Germany. Archiv für Tierzucht 46:113-126.

Swalve, H. H. and S. König. 2007. Test herds in dairy cattle breeding programmes - 1st communication: General considerations. Züchtungskunde 79:249-262.

Thompson, J. R., R. W. Everett, and N. L. Hammerschmidt. 2000. Effects of Inbreeding on Production and Survival in Holsteins. J. Dairy Sci. 83:18561864.

Van Tassell, C. P. and L. D. Van Vleck. 1991. Estimates of Genetic Selection Differentials and Generation Intervals for four Paths of Selection. Journal of Dairy Science 74:1078-1086.

Van Vleck, L. D. 1963. Genotype and Environment in Sire Evaluation. J. Dairy Sci. 46:983-987.

VanRaden, P. M., C. P. Van Tassell, G. R. Wiggans, T. S. Sonstegard, R. D. Schnabel, J. F. Taylor, and F. S. Schenkel. 2009. Invited Review: 
Reliability of genomic predictions for North American Holstein bulls. J. Dairy Sci. 92:16-24.

Vierhout, C. N., B. G. Cassell, and R. E. Pearson. 1999. Comparisons of Cows and Herds in Two Progeny Testing Programs and Two Corresponding States. J. Dairy Sci. 82:822-828.

Wall, E., S. Brotherstone, J. F. Kearney, J. A. Woolliams, and M. P. Coffey. 2005. Impact of Nonadditive Genetic Effects in the Estimation of Breeding Values for Fertility and Correlated Traits. J. Dairy Sci. 88:376-385.

Weigel, K. A. 2004. Exploring the Role of Sexed Semen in Dairy Production Systems. J. Dairy Sci. 87:E120-130.

Weigel, K. A., D. Gianola, B. S. Yandell, and J. F. Keown. 1993. Identification of Factors Causing Heterogeneous Within-Herd Variance Components Using a Structural Model for Variances. J. Dairy Sci. 76:1466-1478.

Wiggans, G. R., P. M. VanRaden, and J. Zuurbier. 1995. Calculation and Use of Inbreeding Coefficients for Genetic Evaluation of United States Dairy Cattle. J. Dairy Sci. 78:1584-1590.

Young, C. W. and A. J. Seykora. 1996. Estimates of Inbreeding and Relationship Among Registered Holstein Females in the United States. J. Dairy Sci. 79:502-505.

Zwald, N. R., K. A. Weigel, Y. M. Chang, R. D. Welper, and J. S. Clay. 2004. Genetic Selection for Health Traits Using Producer-Recorded Data. I. Incidence Rates, Heritability Estimates, and Sire Breeding Values. J. Dairy Sci. 87:4287-4294. 


\title{
$2^{\text {nd }}$ Chapter
}

\section{Genetic and Environmental Impact on Auction Prices for Holstein Cows}

\author{
S. Schierenbeck, S. König, and H. Simianer \\ Institute of Animal Breeding and Genetics, University of Göttingen, \\ 37075 Göttingen, Germany
}




\section{Abstract}

The aim of the present analysis was to determine the impact of a variety of traits and effects (i.e. production, type, health, management effects, pedigree information) on prices of Holstein cows sold at auction, and to estimate genetic (co)variance components between type traits and auction price. Results were used to derive economic weights for type traits. Data of 1565 cows in first parity were collected at six monthly auction sales from August 2005 through January 2006. Seventeen linear type traits and body condition (scale 1 to 9), and four type composites (dairy character, body, feet and legs, and udder; scale 65 to 88) were scored by two classifiers in the auction hall before cows were sold. Analysis of variance revealed a highly significant impact $(P<0.001)$ of auction date, test day milk yield, stage of lactation, origin of sire, and miscellaneous defects on auction price. The most expensive cows were sold in August, they were from foreign proven sires, they had a high level of test day milk yield, and they were free from defects related to udder, feet and legs, or milkability. The feet and leg, udder, and body composite also had a significant effect on the price $(P<0.001)$, with higher scores being associated with higher prices. The opposite association was found for dairy character $(P<0.01)$. Utilizing results from regression analysis, economic weights per genetic standard deviation were highest for linear scored rear udder height $(1.23 €)$, front teat placement $(0.97 €)$, and strength $(0.80 €)$, but were negative for dairy character $(-0.69 €)$. Genetic parameters for linear type traits scored at the auction date were consistent with literature reports. Heritability for auction price was 0.27 , and auction price was genetically positively related to the feet and leg (0.55), udder (0.55), and body composite (0.21). A relative breeding value for auction price was estimated for 27 influential sires, and correlated with official indices for production, conformation, somatic cell count, functional herd life, fertility, and the total net merit index. Correlations were $0.15,0.21,0.11,0.03,0.05$, and 0.19 , respectively. Auction price in combination with type scores and information related to farm management provide valuable information for genetic analysis in dairy cattle, and results can be used to increase dairy cow profitability. 


\section{Introduction}

Worldwide, conformation traits are included in most of the national selection indices for Holstein cattle (Miglior et al., 2005). They are generally used for the national genetic evaluation as indicator traits for udder health (Boettcher et al., 1998), or to predict the length of productive life (Bünger et al., 2001; Schneider et al. 2003; Sewalem et al., 2004). Type traits have a long tradition in German dairy cattle breeding programs (Mügge et al., 1999), and a high emphasis on conformation traits in current breeding goals and selection decisions was reported by Swalve and Höver (2003) and König et al. (2007). However, the inclusion of conformation traits in an overall breeding goal through selection index theory can cause problems. Sophisticated methods for the derivation of economic weights (e.g. Amer et al., 1994) demand a direct impact of traits on costs and revenues, but some conformation traits describing the "beauty" of a cow have only a hypothetical weight (Sölkner et al., 1999).

A possible alternative to derive economic weights for type traits is described by Fürst-Waltl et al. (2004) and Krogmeier et al. (2006). These authors determined the impact of several type traits on auction prices of heifers and of cows, respectively. Both studies, recently conducted in the Simmental dual purpose breed and in Brown-Swiss dairy cattle, revealed a substantial impact of udder, conformation, frame, and rump structure on the market price. Regression analysis, i.e. the change in market price per one unit increase in the score (in genetic standard deviations) for the respective type trait, can be used to derive economic weights (Krogmeier et al., 2006).

The incorporation of type traits in complex breeding goals and the early prediction of longevity through type traits is associated with another problem. It is questionable whether subjectively scored type traits are a reliable database for complex statistical analyses. Beside the subjective classification for type traits, several studies (e.g. Weigel and Lawlor, 1994; Gengler et al., 2006) focused on the problem of heterogeneity in variance and covariance components. In the study by Gengler et al. (2006), heterogeneity of variances was found across different subsets stratified by the size of contemporary groups, the parity of cows, and the average classification for the respective type trait. A substantial heterogeneity of heritabilities for type traits within 
different regions in Germany was also found by Bethge et al. (2005), mainly for traits such as foot angle which are difficult to score in the field. A further problem is that classifiers varied in their score given for the same animal or in the range of the linear scale they used (Bowden, 1982; Swalve and Flöck, 1990; Veerkamp et al., 2002). Although these factors can often be adjusted before genetic evaluation (Brotherstone et al., 1990), a harmonisation of classification results would contribute to more authenticity. Hence, the advantages of a general classification of type traits at auction are as follows: 1.) Several classifiers can score the same animal and several hundred animals can be scored per day, 2.) cows for selling at auction are prepared and showcased similar to each other which could minimize bias in statistical analyses due to preferential treatment (Kuhn et al., 1994), and 3.) breeding organisations save expenses when data recording is more centralized (Swalve and König, 2007).

In the last decade, on average more than 26,000 auction sales per year of breeding stock were transacted in Germany for Holstein dairy cattle (ADR, 2005 ), and $75 \%$ of all sales were from cows in first parity. Based on these impressive quantities, many breeders generate an additional income by selling surplus female cattle at auction. Knowledge about management related characteristics on auction prices, e.g. the optimal length of days in milk or age at first calving, is valuable information for a more economical sales strategy. So far, there were only a few studies addressing this topic in the Holstein breed, and most of them are somewhat out-dated (e.g. Placke, 1982; Ruff et al., 1983).

The objectives of this study were: 1.) to determine the most important management characteristics to achieve higher prices on sale, 2.) to determine the impact of type traits on auction prices for a further application in deriving economic weights, and 3.) to estimate genetic parameters for the trait 'auction price'.

\section{Materials and Methods}

The dataset comprised auction prices, test day production records, and type scores of 1565 first-lactation Holstein cows marketed at six monthly auctions between August 2005 and January 2006 at one auction place in North-West 
Germany. Seventeen linear type traits and body condition (scale 1 to 9 ), and five type composites (dairy character, body, feet and legs, udder, final score; scale 65 to 88) were scored by two classifiers in the auction hall before cows were sold. Both classifiers worked simultaneously on all auction dates and scored the animals alternating. The final score combines the composites for dairy character, body, feet and legs, and udder by weighting factors of 0.15 , $0.20,0.25$, and 0.40 , respectively. A more detailed description related to the recorded linear type traits and type composites for genetic evaluation in German Holstein dairy cattle is given by the VIT (2007). All cows were inspected by a veterinarian at the auction date and deficiencies like clinical mastitis, light quarters, udder warts, substantial feet and leg problems, and obvious reproductive failures were announced during the sale by the auctioneer. Official announcements also included the declaration of insufficient milkability below $1.8 \mathrm{~kg} / \mathrm{min}$. A second dataset consisted of $305-\mathrm{d}$ lactation records and type scores of dams. Variables related to the sires, such as estimated breeding values (EBV) and origin (i.e. German young sire, German proven sire, foreign proven sire, or natural service) were used from the official database for international genetic evaluation from August 2005. Four different models were applied to investigate the impact of type composites and of linear type traits on auction price, and to estimate genetic parameters.

\section{Model 1 for type composites}

The impact of fixed effects as summarized in Table 1 with a main focus on fixed effects of the four type composites (dairy character, body, feet and legs, udder) on auction price was analysed using the GLM procedure (SAS, 1999). Model 1 was:

$y_{i j} \quad=\mu+F_{i}+e_{i j}$

where

$\mathrm{y}_{\mathrm{ij}} \quad=$ auction price of the $\mathrm{i}$-th animal

$\mu \quad=$ overall mean

$\mathrm{F}_{\mathrm{i}} \quad=$ representing all fixed effects for animal $\mathrm{i}$ (see explanations in Table 1)

$\mathrm{e}_{\mathrm{ij}} \quad=$ random residual effect 
Table 1. Levels and P-values of fixed effects from model 1 (F-test, sum of squares type III)

\begin{tabular}{|c|c|c|}
\hline Fixed effect & levels of fixed effects & P-value \\
\hline Date of auction & $\begin{array}{l}\text { August, September, October, } \\
\text { November, December, January }\end{array}$ & $<0.001$ \\
\hline Stage of lactation & $\begin{array}{l}\leq 14 \text { days in milk (dim), 15-28 dim, 29- } \\
42 \mathrm{dim}, 43-56 \mathrm{dim}, 57-70 \mathrm{dim}, \geq 71 \mathrm{dim}\end{array}$ & $<0.001$ \\
\hline Age at first calving & $\begin{array}{l}<25 \text { months, } 25-27,9 \text { months, } 28-30,9 \\
\text { months, 31-33,9 months, } \geq 34 \text { months }\end{array}$ & 0.059 \\
\hline Test day milk yield & $\begin{array}{l}<26 \mathrm{~kg}, 26-27,9 \mathrm{~kg}, 28-29,9 \mathrm{~kg}, 30-31,9 \\
\mathrm{~kg}, 32-33,9 \mathrm{~kg}, 34-35,9 \mathrm{~kg}, \geq 36 \mathrm{~kg}\end{array}$ & $<0.001$ \\
\hline Somatic cell count & $\leq 100,000 ; 101,000-400,000 ; \geq 400,000$ & 0.004 \\
\hline 305-d milk yield of dam & $\begin{array}{l}<7000 \mathrm{~kg}, 7000-8499 \mathrm{~kg}, 8500-9999 \mathrm{~kg} \\
\geq 10,000 \mathrm{~kg}\end{array}$ & 0.053 \\
\hline Final score of dam & $\begin{array}{l}\text { not scored or } \leq 79 \text { points, } 80-82 \text { points, } \\
83-84 \text { points, } \geq 85 \text { points }\end{array}$ & 0.003 \\
\hline Origin of sire & $\begin{array}{l}\text { foreign proven sire, German proven } \\
\text { sire, young sire, natural service }\end{array}$ & $<0.001$ \\
\hline $\begin{array}{l}\text { Announcement of } \\
\text { udder deficiencies }{ }^{1}\end{array}$ & present, absent & $<0.001$ \\
\hline $\begin{array}{l}\text { Announcement of feet } \\
\text { and leg deficiencies }\end{array}$ & present, absent & $<0.001$ \\
\hline $\begin{array}{l}\text { Announcement of } \\
\text { reproductive failures }\end{array}$ & present, absent & 0.069 \\
\hline $\begin{array}{l}\text { Announcement of } \\
\text { milkability deficiencies }\end{array}$ & present, absent & $<0.001$ \\
\hline $\begin{array}{l}\text { Dairy character } \\
\text { composite }\end{array}$ & $\begin{array}{l}\leq 76 \text { points, } 77-78 \text { points, } 79-80 \text { points, } \\
81-82 \text { points, } 83-84 \text { points, } \geq 85 \text { points }\end{array}$ & 0.006 \\
\hline Body composite & $\begin{array}{l}\leq 76 \text { points, } 77-78 \text { points, } 79-80 \text { points, } \\
81-82 \text { points, } 83-84 \text { points, } \geq 85 \text { points }\end{array}$ & $<0.001$ \\
\hline $\begin{array}{l}\text { Feet and leg } \\
\text { composite }\end{array}$ & $\begin{array}{l}\leq 76 \text { points, } 77-78 \text { points, } 79-80 \text { points, } \\
81-82 \text { points, } 83-84 \text { points, } \geq 85 \text { points }\end{array}$ & $<0.001$ \\
\hline Udder composite & $\begin{array}{l}\leq 76 \text { points, } 77-78 \text { points, } 79-80 \text { points, } \\
81-82 \text { points, } 83-84 \text { points, } \geq 85 \text { points }\end{array}$ & $<0.001$ \\
\hline \multicolumn{3}{|c|}{$\begin{array}{l}\text { Announcements of udder deficiencies imply e.g. presence of mastitis or } \\
\text { surplus teats } \\
2 \text { Announcements of feet and leg deficiencies imply e.g. hyperplasia } \\
\text { interdigitalis or digital dermatitis }\end{array}$} \\
\hline $\begin{array}{l}\text { nnouncements of rep } \\
\text { aning still in progress }\end{array}$ & ductive failures imply e.g. retaine & birth or \\
\hline
\end{tabular}




\section{Model 2 for linear scored type traits}

The linear type traits can be separated into four categories (dairy character, body, feet and legs and udder; Table 2). Model 2 was identical to model 1 apart the following changes: a) when analysing the regression of auction price on BCS and dairy character, the fixed effect of the dairy character composite was removed from the model, b) when analysing simultaneously the regression of auction price on stature, body depth, strength, rump angle, and rump width, the fixed effect of the body composite was removed from the model, c) when analysing simultaneously the regression of auction price on rear leg side view, foot angle, hocks, and rear leg set rear view, the fixed effect of the feet and leg composite was removed from the model, and d) when analysing simultaneously the regression of auction price on rear udder height, suspensory ligament, front teat placement, rear teat placement, fore udder attachment, udder depth, and teat length, the fixed effect of the udder composite was removed from the model. This strategy avoids double counting of traits. The four linear traits rump angle, rear leg side view, teat placement rear, and teat length were taken into account with an intermediate optimum. The highest value was given for the score of the intermediate optimum, and deviations from the optimum, regardless below or above, received the same score in the range from 1 to 5 . Values closed to the optimum gave a higher price than scores far apart, and this relationship was linear. The impact of all other linear type traits was modeled as a linear regression, because quadratic or cubic terms were not significant at all $(P>$ 0.05). 


\section{Model 3 and 4 to estimate genetic parameters for auction price and type traits}

Estimation of genetic parameters for the four type composites, the final score, and auction price was done using bivariate animal models for all combinations of type traits and auction price and applying the package ASReml (Gilmour et al., 2000). The model 3 for auction price was:

$\mathrm{y}_{\mathrm{ijk} k \mathrm{~m}}=\mu+\mathrm{SL}_{\mathrm{i}}+\mathrm{FC}_{\mathrm{j}}+\mathrm{DA}_{\mathrm{k}}+\mathrm{a}_{\mathrm{i}}+\mathrm{e}_{\mathrm{ijk} \mathrm{km}}$

and for all type composites and final score, the model 4 was:

$y_{i j k l m n}=\mu+S L_{i}+F C_{j}+D A_{k}+C F_{I}+a_{m}+e_{i j k l m n}$

where SL is the covariate of stage of lactation, FC is the covariate of age at first calving, DA is the fixed effect of date of auction, a refers to the random animal effect, and CF is the fixed effect of the classifier. All other effects were defined as in model 1. Model 4 was also used for unviariate analyses to estimate variance components for the eighteen linear type traits scored at auction. For genetic analyses, relationships among animals were considered back to base animals born in 1940 .

\section{Results and Discussion}

\section{Impact of production, health, management effects, and type composites (model 1)}

Significance values from analysis of variance for all fixed effects (type III test of fixed effects) are shown in Table 1. Most of the effects were highly significant $(P<0.001)$, apart from the 305-d milk yield of the dam, announcement of reproductive failures, age at first calving, and the dairy character composite.

A general overview for the number of sold cows in combination with least square means for auction price by month of auction is depicted in Figure 1. According to the observed trend in previous years for different market places in Germany (ADR, 2005), the number of cows sold in November was twice as high compared to the number of cows sold in August, but auction prices were lower. Hence, the market price was mainly influenced by the ratio of supply and demand. 


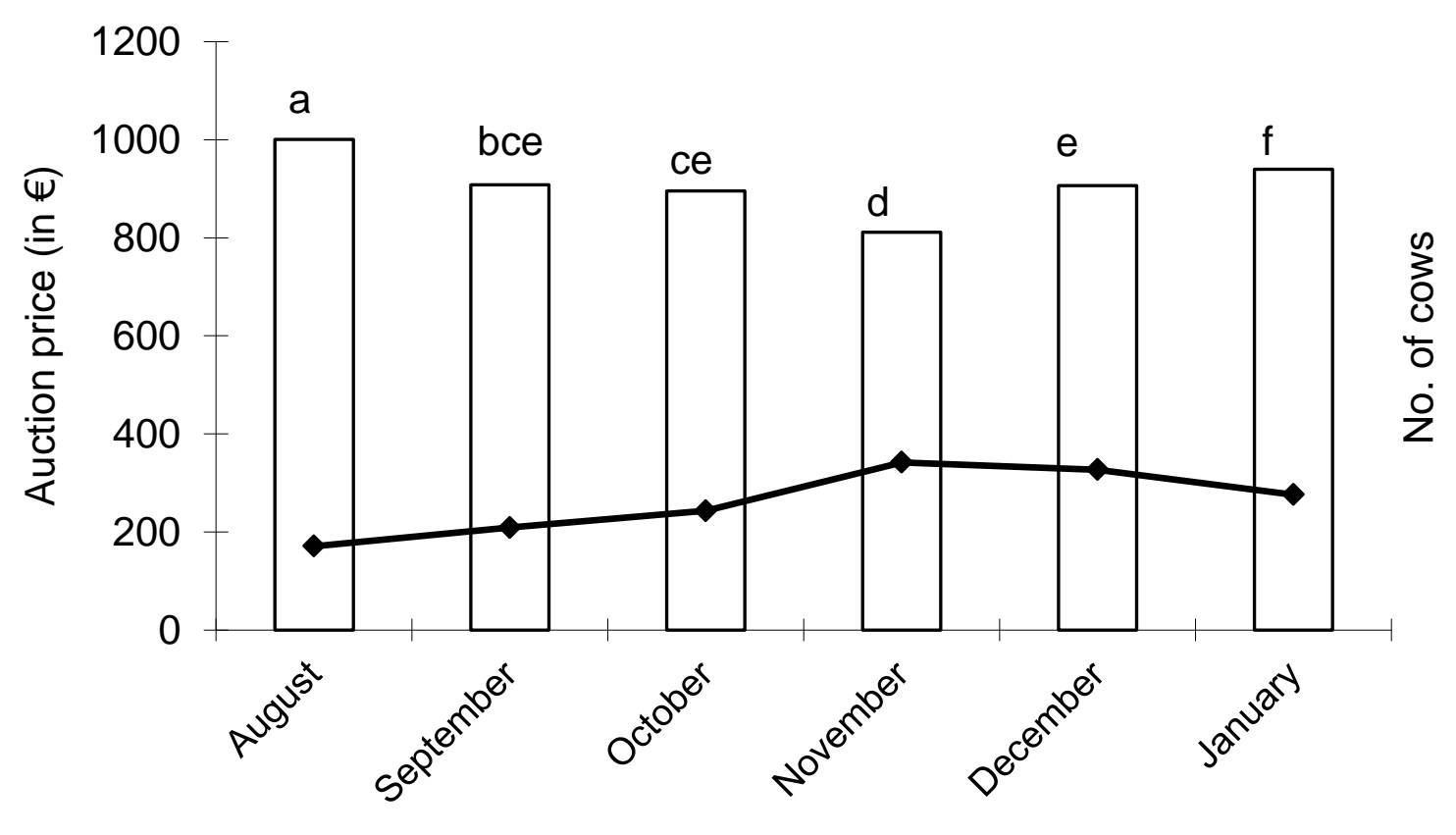

Month of auction

Figure 1. No. of sold cows (black solid line) and LSMeans for the trait "auction price" (in $€$, white bars) by month of auction. Different superscript indicate significant differences of LSMeans $(P<0.05)$.

Age at first calving, another effect related to farm management, had no significant impact $(P>0.05)$ on auction price. Country of origin of the cows' sire (foreign proven, domestic proven, young bull without official EBV, or natural service) had a significant $(P<0.001)$ impact on auction price. Prices of daughters from foreign, proven sires were $29 €$ higher compared to the average market price (Figure 2). As fifty percent of all animals were bought by foreign customers, a reason for this fact might be that those customers favoured daughters from well-known international sires. Lowest prices were paid for daughters from natural service bulls. 


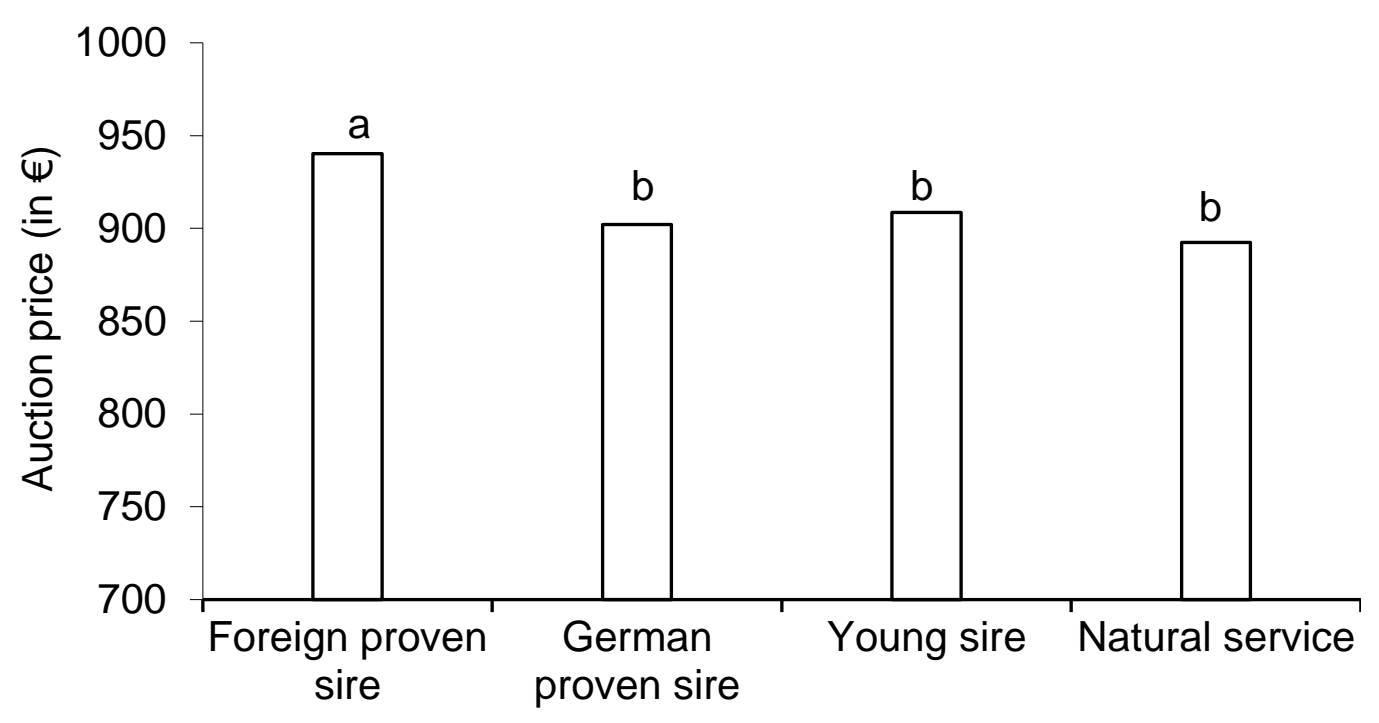

Origin of cow sire

Figure 2. LSMeans for the trait "auction price" (in $€$ ) by classes of origin of sire. Different superscript indicate significant differences of LSMeans $(P<0.05)$.

As shown in Figure 3, an increase of days in milk was associated with a decrease in price for more than 43 days in milk. The main intention of customers is to increase the total amount of milk production on their farms to fulfil the fixed fat quota. As a consequence, cows on sale having already exceeded their lactation peak achieved lower prices. Krogmeier et al. (2006) defined three classes for days in milk. In their study, prices for cows sold within the first 30 days after calving were about $30 €$ higher compared to cows being in a later stage of lactation. 


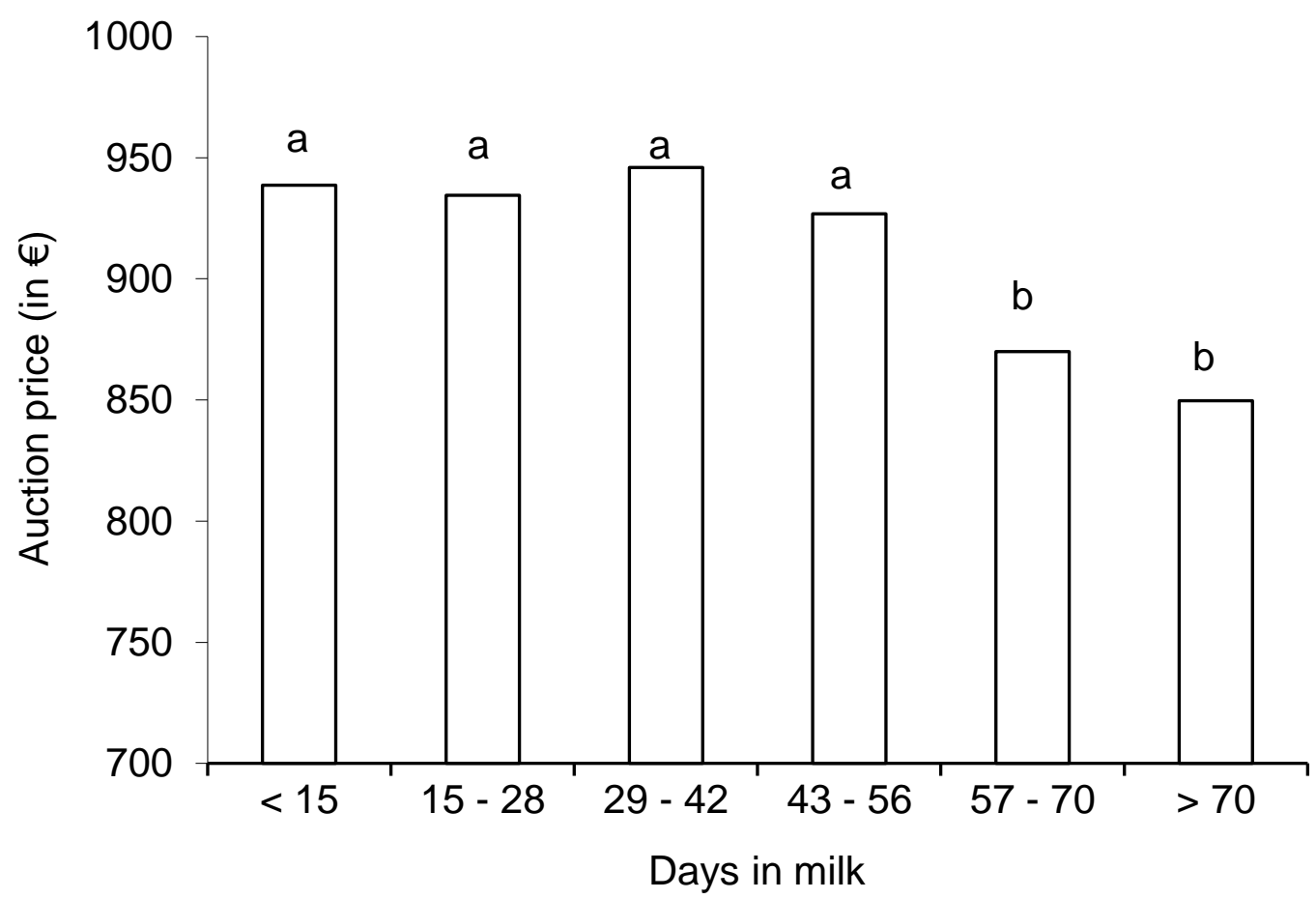

Figure 3. LSMeans for the trait "auction price" (in $€$ ) by classes of days in milk. Different superscript indicate significant differences of LSMeans $(P<0.05)$.

The impact of test day milk yield on market prices is supported by results presented in Figure 4. The difference in market price for cows differing $10 \mathrm{~kg}$ in test day milk yield, e.g. when comparing prices in milk yield class $1(<26$ $\mathrm{kg}$ ) and in milk yield class 7 (> $36 \mathrm{~kg}$ ), was $311 €$. A similar result, i.e. an increase in auction price of $40.5 €$ per $1 \mathrm{~kg}$ of test day milk yield, was reported by Krogmeier et al. (2006). The impact of 305-d lactation milk yield of the dam on auction prices was of minor importance $(P>0.05)$, e.g. a difference of only $43 €$ was observed when comparing extreme classes above $10,000 \mathrm{~kg}$ and below $7,000 \mathrm{~kg}$. This result corresponds to those from Krogmeier et al. (2006). Placke (1982) and Fürst-Waltl et al. (2004) found a substantial impact of dams' milk production on auction prices. However, heifers in their analyses did not have any production records. In such a case, customers put more emphasis on pedigree information. 


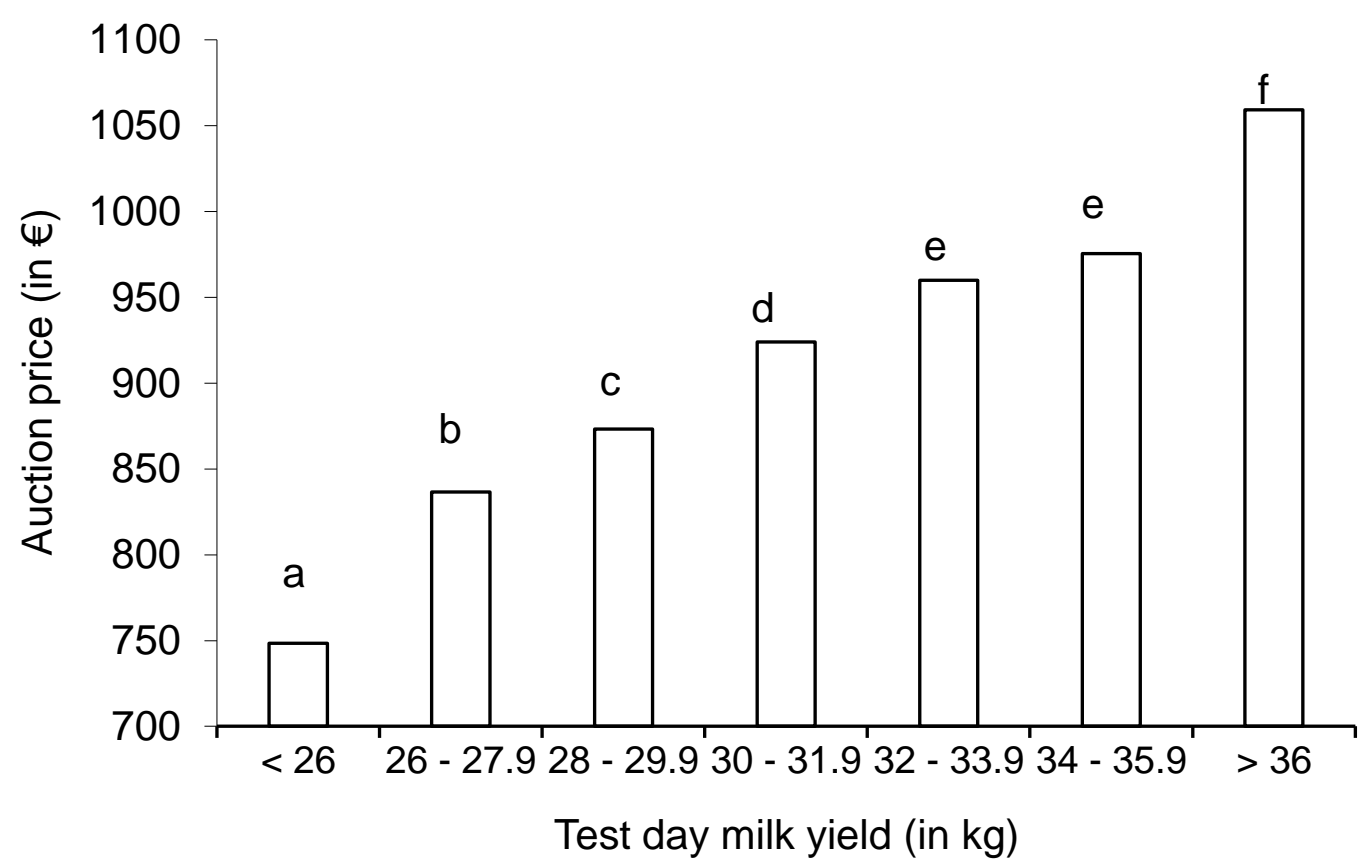

Figure 4. LSMeans for the trait "auction price" (in $€$ ) by classes of test day milk yield. Different superscript indicate significant differences of LSMeans $(P<0.05)$.

The current status of a cow's health strongly determined purchase decisions. Announced deficiencies based on the veterinarians' inspections, i.e. mastitis, feet and leg problems, and reproductive failures, reduced the average market price by $151.40 €, 121.23 €$, and $50.96 €$, respectively (Fig. 5). An additional indicator for udder health is SCC (Philipsson et al., 1995). According to guidelines by Smith et al. (2001), SCC of cows in first parity should be below 100,000 , whereas the range from 100,000 to 200,000 indicates a possible infection, and 200,000 cells or more is a clear signal that an infection is occurring. In our study, test day SCC below 100,000 cells increased the average market price by $38.60 €$. The announcement for insufficient milkability below $1.8 \mathrm{~kg} / \mathrm{min}$ decreased the market price by $103.92 €$ (Figure 5): a comprehensible decision, because milking speed of cows is strongly related to labour (Devir et al., 1993) and costs (Trilk et al., 2005) in dairy cattle farming. 


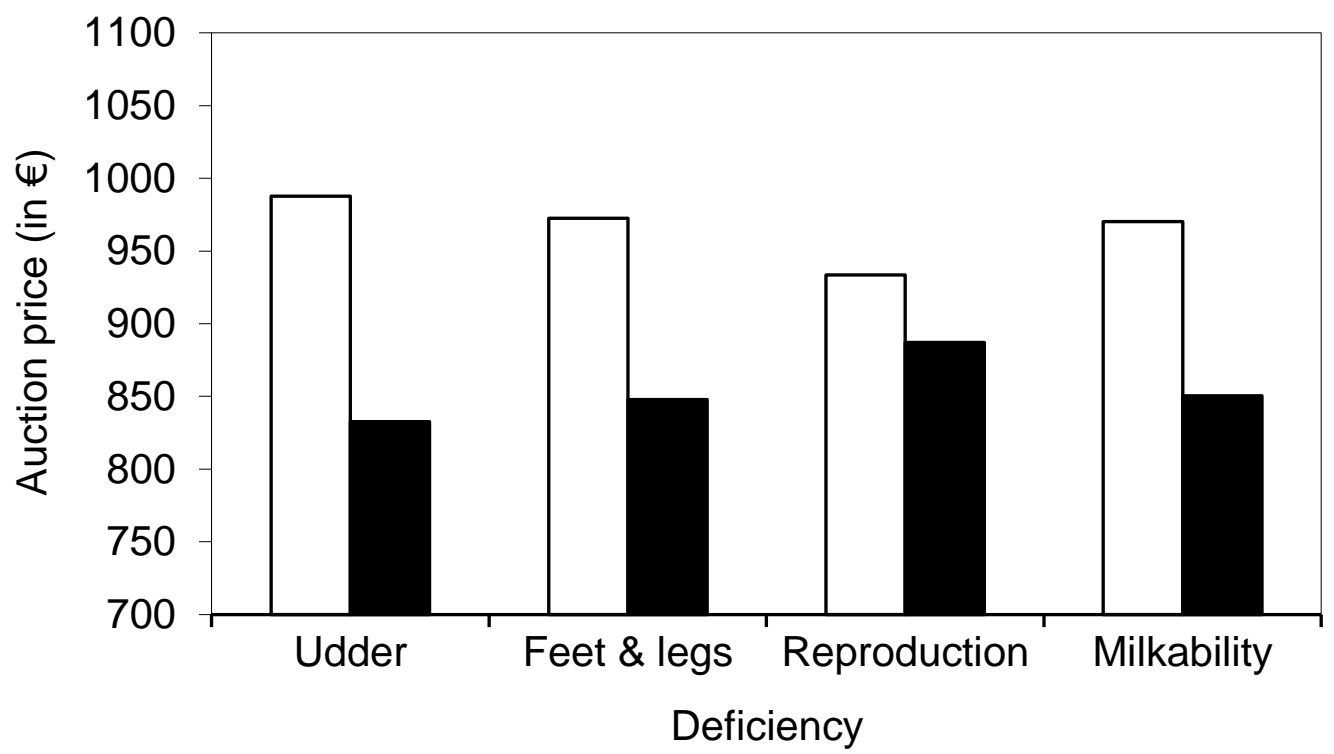

Figure 5. LSMeans for the trait "auction price" (in $€$ ) for several kinds of defiency announcements (white bar = no announcement; black bar $=$ announcement). All pair wise differences were significant apart from reproduction $(P<0.05)$.

The impact of type composites on auction price is shown in Figure 6. As depicted, the score for the udder composite had a significant impact on auction price. Scores of 84 points or above resulted in $227 €$ higher prices compared to udder scores below 77 points. Krogmeier at al. (2006) found a similar price difference between the best and the worst udder class in BrownSwiss and Simmental. Due to their desirable correlations to longevity (Bünger et al., 2001), and claw disorders (König et al., 2005), also higher scores for the feet and leg composite were associated with higher prices. The price difference between the two extreme classes was $126 €$. As shown by FürstWaltl et al. (2004), customers also paid significantly higher prices for cows having higher scores for the body composite. Somewhat surprising were higher prices for lower scores for the dairy character composite. Customers favoured well-conditioned cows, but sharpness at the withers (a main criterion for high scores for dairy character) is highly correlated with less strength and body weight (Dechow et al., 2003). 


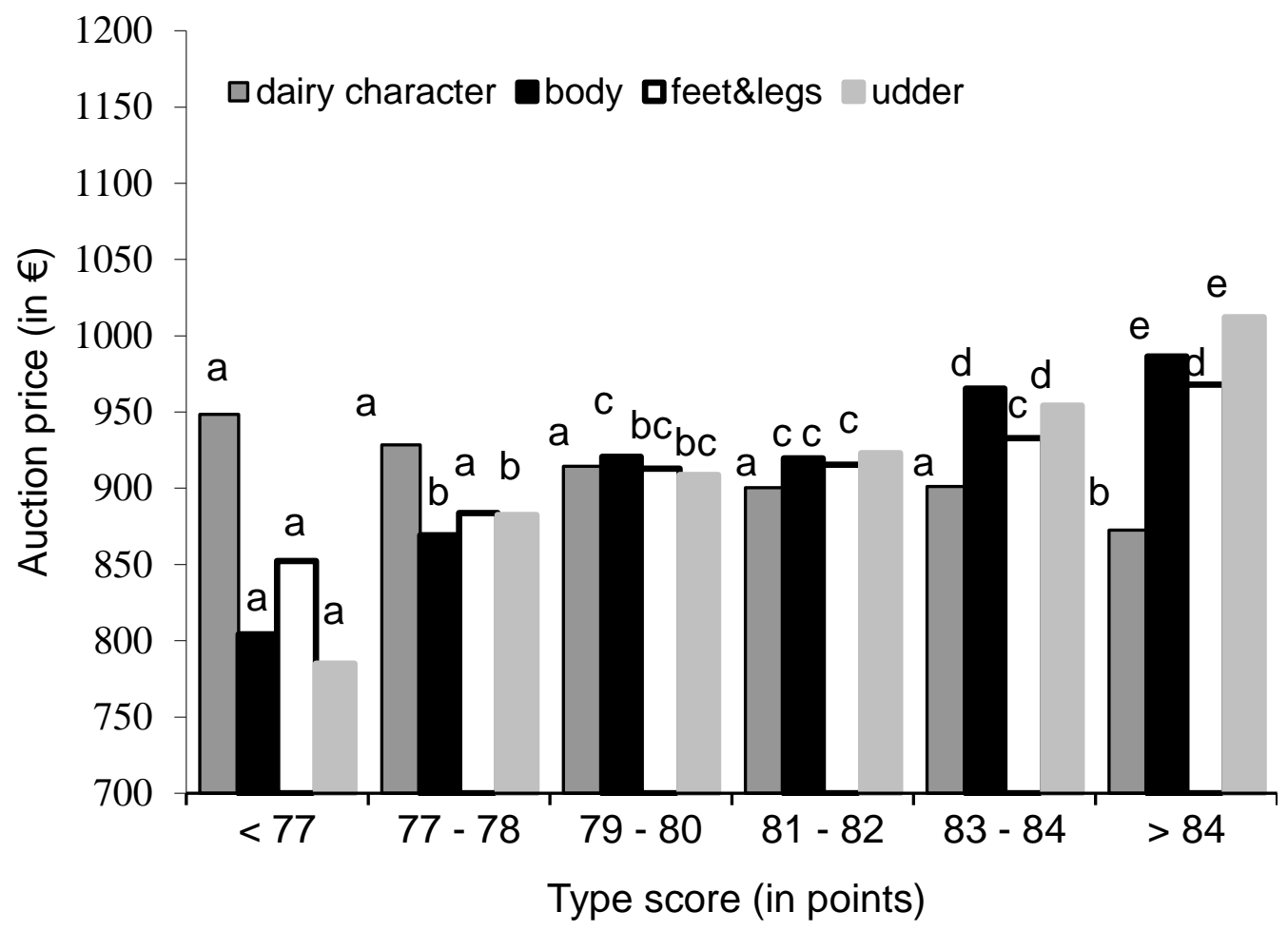

Figure 6. LSMeans for the trait "auction price" (in $€$ ) by classes of scores for the type composites dairy character, body, feet \& legs, and udder. Different superscript within type composites indicate significant differences of LSMeans $(P<0.05)$.

\section{Impact of linear type traits and economic weights}

A main focus of this study was to determine the impact of linear type traits on auction price through the application of linear regression in model 2. Estimated regression coefficients for all linear scored type traits and BCS are provided in Tab. 2. Among all type traits, the largest regression coefficient was estimated for rear udder height ( $29.78 € /$ point), followed by body depth (14.76 €/point), and strength (14.60 €/point). In addition to body depth, all other traits related to the body composite, i.e. stature, strength, rump angle, rump width, and BCS, had positive regression coefficients, indicating that customers favoured higher weights and more capacity of sold cows. As reported for the dairy character composite, also linear scored dairy character had a negative impact (-9.49 €/point) on auction price. This poses the question whether scoring of dairy character should be continued. Dairy character is an indicator for milk production, but objectively measured test 
day milk yield is a much more accurate trait. The additional genetic gain in an overall breeding goal seems to be limited or even counterproductive when including the dairy character component as a predictor for milk yield.

Table 2. Regression coefficients on auction price (standard errors in brackets), variance components, heritabilities ${ }^{1}$, and economic weights for body condition score and 17 linear type traits.

\begin{tabular}{|c|c|c|c|c|c|}
\hline Linear type trait & $\begin{array}{c}\text { Regression } \\
\text { coefficient } \\
(€ / \text { score point) }\end{array}$ & $\sigma_{a}^{2}$ & $\sigma_{e}^{2}$ & $h^{2}$ & $\begin{array}{c}\text { Economic } \\
\text { weight } \\
\left(€ / \sigma_{a}\right)\end{array}$ \\
\hline Body condition score & $5.10(2.40)$ & 0.32 & 1.24 & 0.20 & 0.29 \\
\hline \multicolumn{6}{|c|}{ Dairy character } \\
\hline Dairy character & $-9.49(2.39)$ & 0.54 & 1.30 & 0.29 & -0.69 \\
\hline \multicolumn{6}{|c|}{ Body } \\
\hline Stature (in cm) & $1.95(1.04)$ & 9.19 & 7.95 & 0.54 & 0.59 \\
\hline Body depth & $14.76(3.97)$ & 0.17 & 0.92 & 0.16 & 0.61 \\
\hline Strength & $14.64(3.95)$ & 0.30 & 0.90 & 0.25 & 0.80 \\
\hline Rump angle & $1.93(3.25)$ & 0.33 & 0.73 & 0.31 & 0.11 \\
\hline Rump width & $2.31(3.28)$ & 0.35 & 0.74 & 0.32 & 0.14 \\
\hline \multicolumn{6}{|c|}{ Feet and Legs } \\
\hline Rear leg side view & $2.13(2.96)$ & 0.15 & 1.13 & 0.13 & 0.08 \\
\hline Foot angle & $3.09(2.09)$ & 0.11 & 0.87 & 0.11 & 0.10 \\
\hline Hocks & $9.18(2.63)$ & 0.42 & 1.50 & 0.22 & 0.59 \\
\hline Rear leg set rear view & $9.61(3.03)$ & 0.17 & 1.46 & 0.10 & 0.40 \\
\hline \multicolumn{6}{|c|}{ Udder } \\
\hline Rear udder height & $29.78(3.61)$ & 0.17 & 0.88 & 0.16 & 1.23 \\
\hline Suspensory ligament & $1.04(2.51)$ & 0.30 & 1.89 & 0.14 & 0.06 \\
\hline Front teat placement & $15.14(3.63)$ & 0.41 & 0.61 & 0.40 & 0.97 \\
\hline Rear teat placement & $8.39(4.01)$ & 0.32 & 0.64 & 0.33 & 0.47 \\
\hline Fore udder attachment & $5.81(3.28)$ & 0.45 & 1.35 & 0.25 & 0.39 \\
\hline Udder depth & $-3.76(2.97)$ & 0.49 & 0.60 & 0.45 & -0.26 \\
\hline Teat length & $14.14(3.69)$ & 0.23 & 0.84 & 0.22 & 0.67 \\
\hline
\end{tabular}


Regression coefficients revealed a positive impact for all linear traits belonging to the feet and leg composite in the range from $2.13 € /$ point (rear leg side view) to $9.61 € /$ point (rear leg set rear view) on auction price. Heterogeneous results were found for linear traits of the udder complex, i.e. a pronounced positive impact of rear udder height on auction price (29.78 $€ /$ point), but neutral or slightly negative regression coefficients for suspensory ligament (1.04 $€ /$ point), and udder depth (-3.76 €/point), respectively. Harris et al. (1992) and Short and Lawlor (1992) reported moderately negative genetic correlations between fore udder attachment and udder depth with the three milk production traits. These results suggest that selection for improvement of milk production, which was the main criterion when making purchase decisions about cows at auction, will lead to unfavourable correlated response for udder depth. Hence, purchase decisions were not inevitably related to sustainable breeding strategies. The magnitude of front (14.14 $€ /$ point) and rear teat placement (8.39 $€ /$ point), as well as teat length (14.89 €/point) could be expected, because these "workability" traits are important for the optimisation of the milking process (Rogers and Spencer, 1991), and they are positively correlated with udder health (Lund et al., 1994).

Regression coefficients from model 2 and additive genetic standard deviations $\left(\sigma_{a}\right)$ from model 4 (Table 2) were used for an approximate calculation of economic weights for linear type traits. Economic weights expressed in $€ / \sigma_{a}$ enable a neutral comparison of the importance of individual type traits rather than simple regression coefficients. Additionally, economic weights presented in Table 2 were accounted for the probability of an auction sale or of an exported heifer per average Holstein cow. According to FürstWaltl et al. (2004), economic values estimated from a selected pool of auction cows have to be transformed to values representing the whole population or an average cow in the herd. Hence, a realization factor of 0.1 was assumed, i.e. it was considered that on average ten per cent of the heifers in the population were sold. This means a multiplication of economic weights obtained from regression analyses by factor 0.1 .

The two most important traits were rear udder height $\left(1.41 € / \sigma_{\mathrm{a}}\right)$ and strength $\left(0.80 € / \sigma_{a}\right)$. Fürst-Waltl et al. (2004) discussed the disadvantages of this 
approach, especially the differences in purchase decisions of cows sold in first parity at auction compared to pregnant heifers sold via "conventional" export. Further restrictions have to be applied if a sectoral model is used to derive economic weights. Within a sector, e.g. within the same country, higher prices for cows sold at auction (increased income for some milk producers), have to be compensated by higher costs for customers (increased costs for some other milk producers). An advantage of increased income (higher prices at auction) for some sellers implies the disadvantage of higher costs for buyers. Economic weights derived in this present study show the importance of individual type traits among each other, but additional and more sophisticated steps have to be applied to construct distinct sub-indices for conformation traits in an overall breeding goal. These steps, such as sensitivity analyses, are part of an ongoing research project (Lind et al., 2007).

A strict derivation of economic weights for conformation only based on the influence on auction prices will probably lead to an underestimation of conformation in a combined breeding goal. It should be considered that conformation has additional effects on dairy cow profitability. For example the improvement of the udder composite by one standard deviation was associated with labour time reduction by $54 \mathrm{~min}$ per cow and lactation (Blake and McDaniel, 1979).

\section{Genetic analyses}

Heritabilities for 17 linear type traits and BCS as shown in Table 2 were in the wide range reported by Bethge et al. (2005) when analyzing type traits in 15 different regions within Germany. For example for foot angle, Bethge et al. (2005) estimated heritabilities in the range between 0.06 and 0.17 . The largest heritability among all linear type traits when using auction data was found for stature. Stature was the only objective measurement (in $\mathrm{cm}$ ), whereas the remaining traits were subjectively scored on the scale from 1 to 9. Hence, accurate measurements can reduce the residual component and increase repeatabilities and reliabilities as well. Heritabilities for type composites scored on a 100 point scale were 0.26 for dairy character, 0.11 for body, 0.11 for feet and legs, 0.10 for udder, and 0.11 for the final score 
(Table 3). Heritabilities were relatively small, but, apart from the lower value for the body composite, similar to the results reported by Betghe et al. (2005). As shown in the previous sections of the present study, auction price is determined by a multitude of traits, e.g. milk production, health, and type traits. From the genetic perspective, these results raised the idea to consider the trait "auction price" as an overall breeding goal, and to estimate genetic relationships between currently used national official indices and auction price. Heritability for auction price was 0.27 (Table 3) and therefore larger than all type composites. We found moderate to high genetic correlations between auction price and feet and legs (0.55), and auction price and the udder composite (0.55). The genetic correlation between auction price and dairy character was close to zero. From the genetic point of view, there is no additional contribution of dairy character when defining the trait "auction price" as an ultimate breeding goal.

Table 3: Variance components and heritabilities $\left(\mathrm{h}^{2}\right)$ for auction price and type composites, and genetic correlations $\left(r_{g}\right)$ between auction price and type composites

\begin{tabular}{llllll}
\hline Trait & $\sigma^{2}{ }_{a}$ & $\sigma^{2}{ }_{e}$ & $\sigma_{p}^{2}$ & $h^{2}$ & $r_{g}$ to price \\
\hline Auction price & 7,375 & 19,991 & 27,366 & $0.27 \pm 0.06$ & - \\
Dairy character & 1.49 & 4.22 & 5.71 & $0.26 \pm 0.07$ & $0.10 \pm 0.16$ \\
Body & 0.69 & 5.79 & 6.48 & $0.11 \pm 0.05$ & $0.21 \pm 0.14$ \\
Feet and legs & 0.80 & 6.71 & 7.51 & $0.11 \pm 0.03$ & $0.55 \pm 0.19$ \\
Udder & 0.70 & 6.22 & 6.92 & $0.10 \pm 0.04$ & $0.55 \pm 0.20$ \\
Overall conformation & 0.35 & 2.89 & 3.24 & $0.11 \pm 0.03$ & $0.38 \pm 0.19$ \\
\hline
\end{tabular}


Estimated breeding values for auction price of all animals were standardised to a mean of 100 points and a standard deviation of 12 points. The newly constructed relative breeding value for auction (RZA) was correlated with all official relative breeding values, i.e. the German total merit index (RZG), the production index $(R Z M)$, the conformation index (RZE), the somatic cell count index (RZS), the reproduction index (RZZ), and the functional herd life index $(R Z N)$. The relative weights of the sub-indices $R Z M, R Z E, R Z S, R Z Z$ and RZN in the overall index RZG are 50\%, 15\%,5\%,5\%, and 25\%, respectively. Details for the construction of all sub-indices are given by König et al. (2007). Table 4 shows the correlation coefficients between RZA and remaining relative breeding values for 27 bulls with at least 10 daughters sold at auction (reliability of RZA > 0.60), and for the sold cows itself. The correlations were moderate for RZG, RZM, and RZE in the range between 0.15 (RZM of bulls) and 0.33 (RZE of cows), but close to zero for RZN and even negative $(-0.03)$ for RZZ of cows. However, when interpreting results, the limited sample size for bulls and the low reliabilities of EBVs for cows should be kept in mind. The low correlations between RZA and RZZ could be expected, because the customer has, apart from the announcement of reproduction deficiencies, no information available related to fertility of cows.

Table 4: Correlations between the relative breeding value for auction price $(R Z A)$ and German national official relative breeding values ${ }^{1}$ for bulls and cows

\begin{tabular}{|c|c|c|}
\hline Relative breeding value & $\begin{array}{l}\text { Bulls (> } 10 \text { daughters } \\
\text { sold at auction) }\end{array}$ & Cows sold at auction \\
\hline total merit index (RZG) & 0.19 & 0.29 \\
\hline production index (RZM) & 0.15 & 0.21 \\
\hline conformation index (RZE) & 0.21 & 0.33 \\
\hline $\begin{array}{l}\text { somatic cell count index } \\
\text { (RZS) }\end{array}$ & 0.11 & 0.10 \\
\hline $\begin{array}{l}\text { functional herd life index } \\
\text { (RZN) }\end{array}$ & 0.03 & 0.04 \\
\hline fertility index (RZZ) & 0.05 & -0.03 \\
\hline
\end{tabular}


Based on the high number of more than 20,000 sold Holstein cows at auction per year, it seems to be a reasonable approach to store auction prices in a national electronic database, and to use this information as indicator traits for the improvement of accuracies of correlated national EBVs. For several dairy cattle breeders, auction sales substantially contribute to their monthly income. Profitability could be increased through the knowledge of RZA of individual sires.

\section{Conclusion}

As shown in this study, prices of cows sold at auction reveal several possibilities for analyses related to dairy cow profitability. First of all, the optimisation of management strategies for sales can contribute to additional income for dairy cattle farmers. The most important management effect to achieve higher prices was the choice of a market date early in lactation. A further opportunity, due to the reduced supply of cows on market during the summertime, could be to focus on auction sales in August or September. However, such a strategy implies inseminations in October or November, where heifers are usually kept outdoors. In addition to the identified management effects, there was a moderate genetic contribution to auction prices. Based on the moderate heritability of 0.27 for auction price, it is recommended to provide a relative breeding value for auction price $(R Z A)$, or to use auction price as an indicator trait for the improvement of the udder $\left(r_{g}\right.$ $=0.55)$ and the feet and leg composite $\left(r_{g}=0.55\right)$. The success in breeding programs in Nordic countries, e.g. reduced disease incidences and lower costs, was only possible due to the detailed and extended recording system (Heringstad et al, 2000). This implies the evaluation of all available information sources, also including auction prices, for the general improvement in dairy cow profitability.

It is also possible to derive economic weights for type traits based on their impact on auction prices. However, important type traits identified in the present study through multiple regression analyses (e.g. body depth), are negatively related to functional herd life. Further concerns when deriving economic weights include eventual double-counting of type traits, or 
additional direct impact of type traits on dairy cow profitability such as reduced labour time.

\section{Acknowledgements}

We thank the breeding organisation "Masterrind", Verden for supplying auction prices and linear type data. Vereinigte Informationssysteme Tierhaltung (VIT, Verden) is thanked for providing milk recording data and estimated breeding values.

\section{References}

ADR, 2005. Annual Statistics. German Cattle Breeders Federation. Bonn, Germany.

Amer, P.R., Fox, G.C., Smith, C. 1994. Economic weights from profit equations: appraising their accuracy in the long run. Anim. Prod. 58, 1118.

Bethge, M., Wensch-Dorendorf, M., Swalve, H.H., 2005. Schätzung von Varianzkomponenten am Material der linearen Exterieurbeschreibung beim Holstein Rind. Vortragstagung der DGfZ und GfT, 21./22.09.05, Berlin.

Blake, R.W., McDaniel, B.T., 1979. Relationship of udder conformation with labor and machine inputs to milk harvest in dairy cattle. J. Dairy Sci. 62, 475-485.

Boettcher, P.J., Dekkers, J.C.M., Kolstad, B.W., 1998. Development of an udder health index for sire selection based on somatic cell score, udder conformation, and milking speed. J. Dairy Sci. 81, 1157-1168.

Bowden, B., 1982. Type classification in dairy cattle: a review. Anim. Breed. Abstr. 50, 147-162.

Brotherstone, S., McManus, C.M., Hill, W.G., 1990. Estimation of genetic parameters for linear and miscellaneous type traits in Holstein-Friesian dairy cattle. Livest. Prod. Sci. 26, 177-192.

Bünger, A., Ducrocq, V., Swalve, H.H., 2001. Analysis of survival in dairy cows with supplement data on type scores and housing systems from a region of northwest Germany. J. Dairy Sci. 84, 1531-1541. 
Dechow, C.D., Rogers, G.W., Klei, L., Lawlor, T.J., 2003. Heritabilities and correlations among body condition score, dairy form and selected linear type traits. J. Dairy Sci. 86, 2236-2242.

Devir, S., Renkema, J.A., Huirne, R.B.M., Ipema, A.H., 1993. A new dairy control and management system in the automatic milking farm: Basic concepts and components. J. Dairy Sci. 76, 3607-3616.

Fürst-Waltl, B., Wieser, J., Fürst, C., Sölkner, J., 2004. Einfluss des Exterieurs auf den Versteigerungspreis von Fleckvieh- und BraunviehKalbinnen. Züchtungskunde 76, 149-161.

Gengler, N., Wiggans, G.R., Thornton, L.L.M., Wright, J.R., Druet. T., 2006. Accounting for heterogeneous variances in multitrait evaluation of Jersey type traits. J. Dairy Sci. 89, 3143-3151.

Gilmour, A.R., Cullis, B.R., Welham, S.J., Thompson, R., 2000. ASREML. Program user manual. NSW Agriculture, Orange Agricultural Institute, Forest Road, Orange, NSW, 2800, Australia.

Harris, B.L., Freeman, A.E., Metzger, E., 1992. Genetic and Phenotypic Parameters for type and Production in Guernsey Dairy Cows . J Dairy Sci 75, 1147-1153.

Heringstad. B., Klemetsdal, G., Ruane, J., 2000. Selection for mastitis resistance in dairy cattle-a review with focus on the situation in Nordic countries. Livest. Prod. Sci. 64, 95-106.

König, S., Sharifi, R., Wentrot, H., Landmann, D., Eise, M., Simianer, H., 2005. Genetic parameters of claw and foot disorders estimated with logistic models. J. Dairy Sci. 88, 3316-3325.

König, S., Lessner, S., Simianer, H., 2007. Application of controlling instruments for improvements in cow sire selection. J. Dairy Sci. 90, 19671980.

Krogmeier, D., Luntz, B., Götz, K.-U., 2006. Untersuchungen zur ökonomischen Bewertung von Exterieurmerkmalen bei Braunvieh und Fleckvieh anhand von Jungkuh-Auktionsdaten. Züchtungskunde 78, 464478.

Kuhn, M.T., Boettcher, P.J., Freeman, A.E., 1994. Potential bias in transmitting abilities of females from preferential treatment. J. Dairy Sci. $77,2428-2437$. 
Lind, B., Schierenbeck, Reinhardt, S., F., Simianer, H., 2007. Do type traits have an economic value in dairy cows? Proc. $58^{\text {th }}$ EAAP-Meeting, Dublin, Ireland.

Lund, T., Miglior, F., Deckers, J.C.M., Burnside, E.B., 1994. Genetic relationships between clinical mastitis, somatic cell count, and udder conformation in Danish Holsteins. Livest. Prod. Sci. 39, 243-251.

Miglior, F., Muir, B.L., Van Doormaal, B.J., 2005. Selection indices in Holstein cattle of various countries. J. Dairy Sci., 88, 1255-1263.

Mügge, B., Lutz, W.E., Südbeck, H., Zelfel, S., 1999. Deutsche Holsteins: Die Geschichte einer Zucht. Verlag Eugen Ulmer.

Philipsson, J., Ral, G., Berglund, B., 1995. Somatic cell count as a selection criterion for mastitis resistance in dairy cattle. Livest. Prod. Sci. 41, 195200.

Placke, K.-H. 1982. Untersuchung zur Exterieurbeurteilung in der Schwarzbuntzucht. PhD Thesis, University of Kiel.

Rogers, G.W., Spencer, S.B., 1991. Relationships among udder and teat morphology and milking characteristics. J. Dairy Sci. 74, 4189-4194.

Ruff, N.J., Vinson, W.E., Pearson, R.E., White, J.M., Meland, O.M., Edlund, D.P., 1983. Factors affecting price differences within sales of registered Holstein cattle. J. Dairy Sci. 66, 587-594.

SAS Institute Inc., 1999. SAS/STAT User's guide, Version 8. Cary, NC, USA. Schneider, M. del P., Dürr, W.R., Cue, R.I., Monardes, H.G., 2003. Impact of type traits on functional herd life of Quebec Holsteins assessed by survival analysis. J. Dairy Sci. 86, 4083-4089.

Sewalem, A., Kistemaker, G.J., Miglior, F., Van Doormaal, B.J., 2004. Analysis of the relationship between type traits and functional survival in Canadian Holsteins using a Weibull proportional hazards model. J. Dairy Sci. 87, 3938-3946.

Short, T.H., Lawlor, T.J., 1992. Genetic parameters of conformation traits, milk yield, and herd life in Holsteins. J. Dairy Sci. 75, 1987-1998.

Smith, K.L., J.E. Hillerton \& R.J. Harmon. 2001. Guidelines on normal and abnormal raw milk based on somatic cell counts and signs of clinical mastitis. NMC, Inc., Madison WI. 
Sölkner, J., Willam, A., Gierzinger, E., Egger-Danner, C., 1999. Effects of including conformation in total merit indices of cattle. Interbull Bull. No. 23., 143-150.

Swalve, H.H., Flöck, D., 1990. Berücksichtigung von Beurteilermittelwert und -standardabweichung als wichtige Einflußgrößen bei der Analyse von Daten der linearen Exterieurbeschreibung. Züchtungskunde 62, 367-383.

Swalve, H.H., Höver, K., 2003. Examinations using the results of breeding value estimation for Holstein sires and cows in Germany. Arch. Tierz. 46, 113-126.

Swalve, H.H., König, S., 2007. Testherden in Zuchtprogrammen für Milchrinder. 1. Mitteilung: Allgemeine Überlegungen. Züchtungskunde 79, 249-263.

Trilk, J., Zube, R., May, D., 2005. Management, Kostenaufwand und Wirtschaftlichkeit Automatischer Melksysteme in Auswertung mehrjähriger praktischer Nutzung. Züchtungskunde 77, 256-270. 


\title{
$3^{\text {rd }}$ Chapter
}

\section{Identification of Informative Cooperator Herds for Progeny Testing Based on Yield Deviations}

S. Schierenbeck, ${ }^{\star} \dagger$, F. Reinhardt ${ }^{\dagger}$, R. Reents, ${ }^{\dagger}$, H. Simianer ${ }^{*}$ and S. König, ${ }^{\#}$

\begin{abstract}
*Animal Breeding and Genetics Group, Department of Animal Sciences, Georg-August-University of Göttingen, 37075 Göttingen, Germany †Vereinigte Informationssysteme Tierhaltung w.V., D-27283 Verden, Germany

\#Department of Animal Breeding, University of Kassel, 37213 Witzenhausen, Germany
\end{abstract}

published in Journal of Dairy Science 


\section{Abstract}

There are several arguments for breeding organizations to focus on cooperative herds for progeny testing, but there is a substantial lack of efficient methodology addressing herd selection strategies. In this study, a new approach based on yield deviations (YD) to identify most informative cooperator herds in terms of genetic differentiation was evaluated. Data comprised YD from 717,377 first lactation cows from two regions in East and West Germany calving between January 2003 and January 2008. Daughters were ranked and classified within sire according to their YD for protein yield, fat yield, milk yield and somatic cell score (SCS). Cows in created YD classes were merged with respective herd-calving year (HCY) characteristics. Cows of extreme YD classes, i.e. such classes including the most extreme daughter contributions, belonged to herds characterized by a high $\mathrm{HCY}$ production level, a low value for $\mathrm{HCY}$ somatic cell count, and a low $\mathrm{HCY}$ age at first calving. Cows with low extremes for YD in protein yield were associated with the lowest $\mathrm{HCY}$ production level, a high value for $\mathrm{HCY}$ somatic cell count, and a late HCY age at first calving. Ranks of HCY and ranks of herds considering $\mathrm{HCY}$ over the whole analyzed period were calculated by averaging YD percentages within $\mathrm{HCY}$, and within herds, respectively. YD percentages (in absolute values so that negative and positive daughter contributions were treated equally) were derived from the rank of the YD of a daughter within sire in relation to all daughters of a sire. A further partitioning of ranks of herds into quartiles revealed the following results: herds in the first quartile had the highest average protein yield, the highest intra-herd standard deviation for the national production index, and the lowest age at first calving. Correlations between herd rankings for different production traits ranged between 0.64 and 0.86 , and were 0.65 for West Germany and 0.62 for East Germany between HCY 2006 and the average herd rank of all calving years. Correlations between DYD for the highest and the lowest herd quartile of 0.87 for protein yield disproved concerns regarding genotype by environment interaction between test and production environment. The suggested methodology to identify informative cooperator herds is easy to implement, holds for regions with small herd 
sizes, and thus, may help implementing sustainable and competitive dairy cattle breeding programs.

\section{Introduction}

Progeny testing (PT) in dairy cattle as suggested by Henderson (1964), and by Skjervold and Langholz (1964), was established in Germany in the late sixties. The original idea included a random mating system for young sires to generate a substantial pool of phenotypes for an unbiased estimation of breeding values (EBV). This random mating system implied a random sample of herds used for PT (or even all herds within the active breeding population), and a random sample of cows within herds for inseminations with young sires. Apart from long generation intervals, PT in this form generated relatively high selection intensities, and highly reliable EBVs for the male pathways of selection. The final improvement for those components was associated with a sustained selection response for traits under intensive selection pressure (König et al., 2007).

Further improvements to identify genetically superior sires could be put into effect by selecting special cooperator herds for PT. This idea was formulated by Hammond (1947), who suggested to keep and to select animals in superior environments, so that animals can fully express their true genetic potential. Other studies also discussed possible genotype by environment interactions when differentiating between test environment and production environment (e.g. König et al., 2008), which underlines the importance of a broad testing scheme in a multitude of herds. As found in several studies (e.g. Hill, 1984; Garrick and Van Vleck, 1987), differences in test environments have been associated with differences in estimated variance components. The impact of heterogeneous variances across regions or herds on results of genetic evaluation for production traits has been discussed intensively (Van Vleck, 1963; Vinson, 1987; Boldman and Freeman, 1990). Former publications (e.g. Van Vleck,1963), as well as more recent studies (e.g. Gernand et al., 2007) found higher additive genetic variances with an increasing production level in herds, and they gave recommendations for optimization of PT schemes. Simulation studies by Hill (1984) and Garrick and Van Vleck (1987) showed an increase of EBVs with 
increasing intra-herd variances. The optimization of management and feeding strategies (Padilla and Keown, 1990), the milking technology and herd size (Weigel et al., 1993) as well as the skills of herdsmen (Short et al., 1990) were identified as possible reasons for increased intra-herd variances. Since the unification of the two formerly separated German countries in 1990, the German dairy cattle population is characterized by a dichotomy in housing and management conditions: In West Germany, family farms with herd sizes of around 30 to 100 cows are prevalent, whereas in East Germany large-scale dairy farms with herd sizes of 200 to 2000 cows are common. Also for Germany, heterogeneity in variance components for production traits was found (König et al., 2005a): the larger the farm, the larger the additive genetic variance. A reason for this could be that relationships between genotype and management (e.g. as arising from feeding according to the genetic potential) are higher in large farms.

Due to the increase of competition on the global semen market for dairy sires (Dekkers et al., 1996), some of the 14 different German breeding organizations refresh those ideas towards more selective PT in terms of test environments to achieve more accurate EBVs. Additionally, higher accuracy to identify genetically superior sires among the total pool of test candidates will increase genetic gain as well as production level in the whole population. However, there is a lack of effective methods to identify those informative cooperator herds allowing the highest genetic differentiation. Some studies have focused on relatively simple aspects, e.g. the number of usable records (Meinert et al., 1997), or herd size and herd production level (Vierhout et al., 1999). Gernand et al. (2007) suggested cluster analyses to combine favourable effects of large herd size, high production level, and low age at first calving (AFC). Other studies (e.g. Brügemann, 2008; Dechow et al., 2008a) focussed on genetic analyses and variance component estimation within herds. Brügemann (2008) found increasing additive genetic variances and heritabilities with increasing herd size and improving farm management. In the study by Dechow et al. (2008a), intra-herd heritability was also negatively correlated with sire misidentification rates. Due to relatively large standard errors of estimates from intra-herd analyses, this approach is not applicable for small family farms as prevalent in West Germany. 
As an alternative, we evaluated a strategy for selection of cooperator herds based on yield deviations (YD). The derivation and calculation of daughter yield deviations (DYD) and YD was reported by VanRaden and Wiggans (1991) for animal models, and by Mrode and Swanson (2004) for random regression models. DYD have been described as the most independent and most accurate measure of phenotypic performance of a bull, conceptually equivalent to average daughter records (VanRaden and Wiggans, 1991; Liu et al., 2004; Mrode and Swanson, 2004). Utilization of DYD for dairy cattle genetic evaluation and breeding objectives is quite common: DYD are used as controlling instruments at Interbull for validating trends in national genetic evaluations (Boichard et al., 1995), for the identification of preferential treatment (Powell et al., 1994), or for the identification of quantitative trait loci and derivation of SNP effects (Szyda et al., 2005; Neuner et al., 2008).

The specific goal of the present study was to investigate the association between YD and defined herd characteristics. Based on these findings, an approach using YD to select cooperator herds for PT is suggested.

\section{Material and methods}

\section{Data}

The data consisted of 3,652,113 test day records from 445,819 first lactation cows in 26,651 herd-calving years (HCY) located in the German state Lower Saxony (Northern part of West Germany), and of 2,244,185 test day records from 271,558 first lactation cows in 3,483 HCY located in Saxony (East Germany). Data from West Germany generally represent the typical family farm in this region with an average herd size of 16.7 cows in first lactation. Average herd size for large-scale dairy farms in East Germany comprised on average 68 cows in parity one. Cows calved between January 2003 and January 2008, and test day records for all cows were available for this period. Furthermore, yield deviations for milk yield, fat yield, protein yield, and somatic cell count for these cows were available. Yield deviations were calculated as lactation yield deviations, i.e. based on the cow's performance adjusted for fixed and non-genetic random effects, and for genetic effects of the dam. Details for the calculation of YD and criteria for publication of YD are explained in Liu et al. (2004). 
Records from cows that had their first herd test day later than 60 days after calving (presumably due to herd changes) and records from cows without a second calving were excluded from the analyses. An additional requirement for keeping a cow record was a registered sire with more than 50 daughters, resulting in cows from 833 different sires. This strategy also excluded natural service sires. The final data set consisted of 265,667 cows in 22,668 HCY from West Germany, and of 173,567 cows in 3,410 HCY from East Germany. Means and standard deviations averaged over the first five test records for milk yield, fat content, protein content, somatic cell count, calving interval $(\mathrm{Cl})$, and age at first calving for both regions are shown in Table 1. 
Table 1. Means and standard deviations (SD) averaged over the first five test day records for milk yield, fat content, protein content, somatic cell count, calving interval and age of first calving for the regions West Germany and East Germany within calving years. calving year parameters

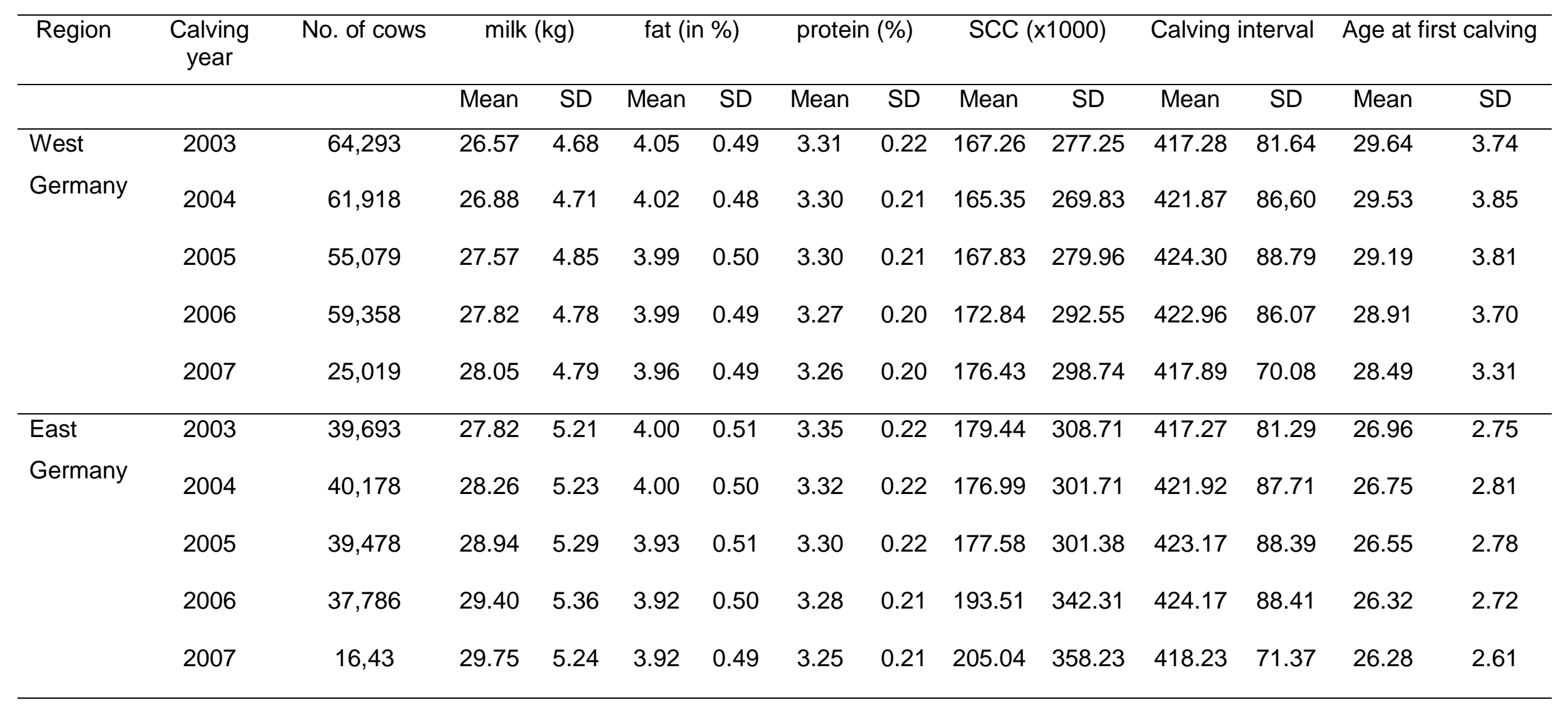




\section{Method}

\section{Ranking of daughters within sire and allocating daughters to $\mathrm{HCY}$}

An initial, general analysis was conducted to verify possible associations between YD and respective HCY parameters. For this purpose, cows were classified in seven different YD classes (Table 2). All cows were ranked within sire by the magnitude of their YD. Subsequently, the cows were assigned to different YD classes, e.g. the 10\% cows with the highest YD within their sire were assigned to class "highest 10 ", and the $20 \%$ with the highest YD within sire (from 0 to $20 \%$ ) were assigned to class "highest 20 ". Cow records in defined YD classes were merged with phenotypic observations of their remaining $\mathrm{HCY}$ contemporaries to calculate $\mathrm{HCY}$ parameters. These were:

1. average $\mathrm{HCY}$ protein yield (average of first five test day records)

2. average $\mathrm{HCY}$ somatic cell score (average of first five test day records)

3. average $\mathrm{HCY}$ calving interval

4. average $\mathrm{HCY}$ age of first calving

A study focusing on the first five test day records is in line with criteria for early selection strategies of young sires. Furthermore, genetic differentiation is less pronounced at the end of the lactation due to a decrease in additive genetic variances (Gernand et al., 2007). Analyses were conducted separately for YD classification based on the following traits: 1. YD for milk yield, 2. fat yield, 3. protein yield, and 4. SCS.

Table 2. Yield deviation (YD) classes used to analyze possible associations between YD and respective herd-calving year parameters

\begin{tabular}{|c|c|c|}
\hline YD class & Range & Percentile \\
\hline lowest $10 \%$ & $10 \%$ of daughters with lowest YD within sire & 0 to 9 \\
\hline lowest $20 \%$ & $20 \%$ of daughters with lowest YD within sire & 0 to 19 \\
\hline lowest 30\% & $30 \%$ of daughters with lowest YD within sire & 0 to 29 \\
\hline average $40 \%$ & $\begin{array}{l}40 \% \text { of daughters with low extremes for YD within } \\
\text { sire, i.e. those cows between the lowest } 30 \% \text { and } \\
\text { the highest } 30 \%\end{array}$ & 30 to 69 \\
\hline highest $30 \%$ & $30 \%$ of daughters with highest YD within sire & 70 to 99 \\
\hline highest $20 \%$ & $20 \%$ of daughters with highest YD within sire & 80 to 99 \\
\hline highest $10 \%$ & $10 \%$ of daughters with highest YD within sire & 90 to 99 \\
\hline
\end{tabular}




\section{Selection of most informative cooperator herds}

For optimization of genetic differentiation, those herds are most informative which include a high fraction of cows with extreme genetic contributions (high or low), e.g. such cows classified in YD-classes "highest 10\%" and "lowest $10 \%$ ". In terms of the phenotypic expression of the genetic potential, average YD or YD with low extremes as prevalent in YD-class "average 40" within sire are unfavorable. Our approach thus focused on the identification of herds providing extreme YD within sire, treating negative and positive YD equally. Identification of cooperator herds based on this strategy does not focus on the success of a breeding organization with respect to the number of bulls in the national top list rather than a more accurate genetic differentiation.

For treating positive and negative daughter contributions equally, all cows within sire were ranked in percentages by extremeness of their YD, in negative as well as in positive direction. Hence, most extreme YDs in both directions imply high values for daughter rank percentages. In the next step, herd-calving year ranks (HCYrank) were created by utilizing the defined "within-sire percentages" and applying the following formula:

$$
\text { HCYrank }_{j l}=\frac{\sum\left|\operatorname{perc}_{i j k l}\right|}{n_{j l}}
$$

where $\mathrm{HCYrank}_{j l}$ is the rank of herd $j$ in calving year $l ; \mid$ perc $_{i j k} \mid$ is the absolute value of the percentage score of cows $i$ from herd $j$ within sire $k$ in year $l$; and $n_{j l}$ is the number of cows in herd $j$ in calving year $l$. Furthermore, the rank of a herd, that considered all available HCY within the entire analyzed period, was calculated as follows:

$$
\text { Rank of herd }_{j}=\frac{\sum\left|\operatorname{perc}_{i j k}\right|}{n_{j}}
$$

where $\mid$ perc $c_{i j k} \mid$ is the absolute value of the percentage score of cow $i$ from herd $j$ within sire $k$; and $n_{j}$ is the number of cows in herd $j$.

An example for calculating the HCYrank for one specific small $\mathrm{HCY}$ with three cows from two different sires in first lactation is given in Fig. 1. As explained, at first cows were ranked by extremeness of their $Y D$ within sire. $A$ percentage score of $-42.1 \%$ was assigned to cow $A$ which implies that this cow represents the $42.1 \%$ percentage of all cows below the DYD of the respective sire $\mathrm{A}$. Cow $\mathrm{B}$ represents the $80.7 \%$ percentage of all cows above 
the DYD of sire A. Cow $C$ has a percentage score of $21.2 \%$ indicating that within all daughters of sire $B$ that have a YD above the sires DYD cow $C$ represents the $21.2 \%$ most positive YD. Subsequently, absolute values of the percentage scores of all cows belonging to the $\mathrm{HCY}$ in this example are averaged to calculate the HCYrank of $48 \%$ :

$$
\text { HCYrank }=\frac{|-42.1 \%|+80.7 \%+21.2 \%}{3}=48 \%
$$

The procedure as explained in Fig. 1 was subsequently used to calculate the rank of a herd using cows from all $\mathrm{HCY}$.

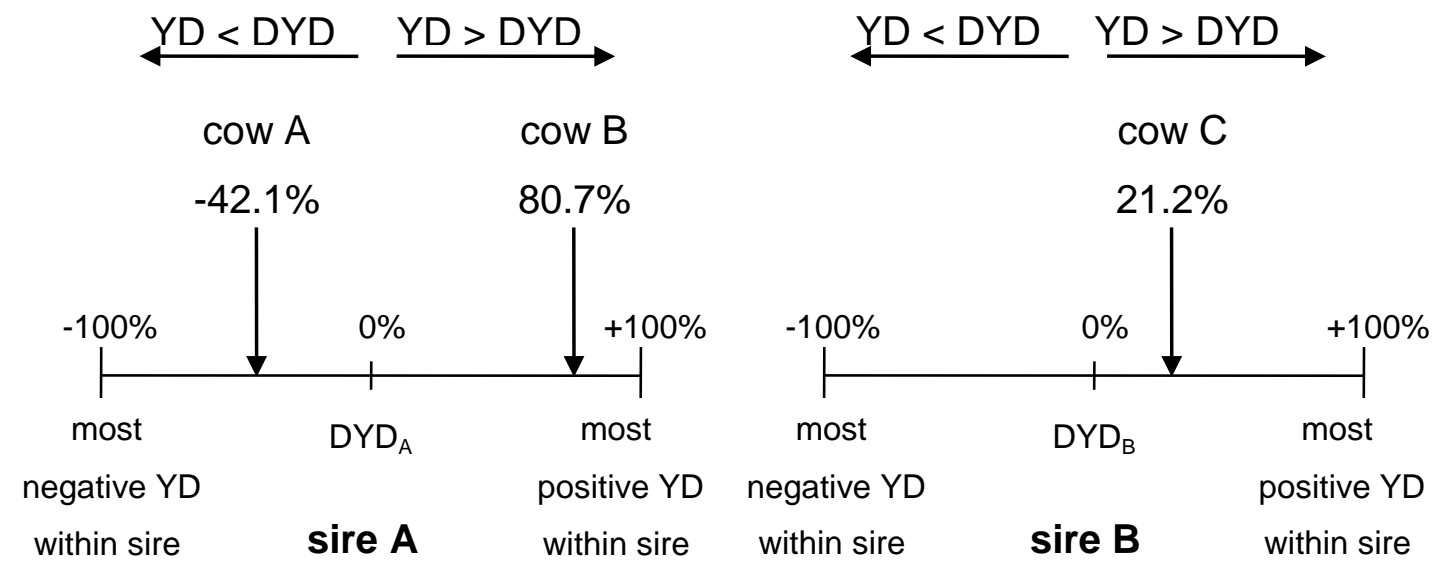

Figure 1. Example for ranking one specific herd-calving year (HCY) including three cows in first parity from two different sires: Cows were ranked by extremeness of their YD within sire. Subsequently absolute values of the percentages within sire were averaged for each $\mathrm{HCY}$ to create $\mathrm{HCY}$ ranks. 
In the last step, herds were classified into quartiles according to their rank of herd. The lower the herd quartile, the more extreme YD were allocated. Low quartile herds were suggested as a cooperator herd for PT with respect to genetic differentiation. For each herd quartile, means for the following herd characteristics were calculated:

- herd size defined as the average number of first lactation cows per HCY

- protein yield (average of first five test day records)

- intra herd standard deviation for the German production index (RZM)

- age at first calving

Analyses were restricted to herds with at least 10 first lactation cows in calving year 2006, and were conducted separately using YD for milk yield, fat yield, protein yield and somatic cell score. Spearman rank correlations were calculated between herd rankings for different traits, and between HCYranks within the same trait.

\section{Analysis of genotype by environment interactions}

Possible genotype by environment interactions (GxE) for protein yield and somatic cell count between high and low ranking herds were analyzed by correlating DYD of sires between the highest and lowest herd quartile. Data comprised 54,346 cows in the $1^{\text {st }}$ herd quartile and 39,951 cows in the $4^{\text {th }}$ herd quartile for West Germany, as well as 40,193 cows in the $1^{\text {st }}$ herd quartile and 22,276 cows in the $4^{\text {th }}$ herd quartile for East Germany. DYD for a sire was the average of YD of his daughters in the respective herd quartile. Subsequently, Spearman rank correlations were calculated between sire's DYD in different herd quartiles and different regions. The first analysis considered all sires, and was restricted in a second analysis to sires with at least 50 daughters in both environments. In absence of GxE, ranking of sires is expected to be similar in both environments. 


\section{Results and Discussion}

\section{Associations between YD and herd parameters}

Means for HCY test day protein yield, HCY somatic cell count, HCY calving interval, and HCY age of first calving stratified by region and YD classes for protein yield and somatic cell count are shown in Figures 2 to 5.

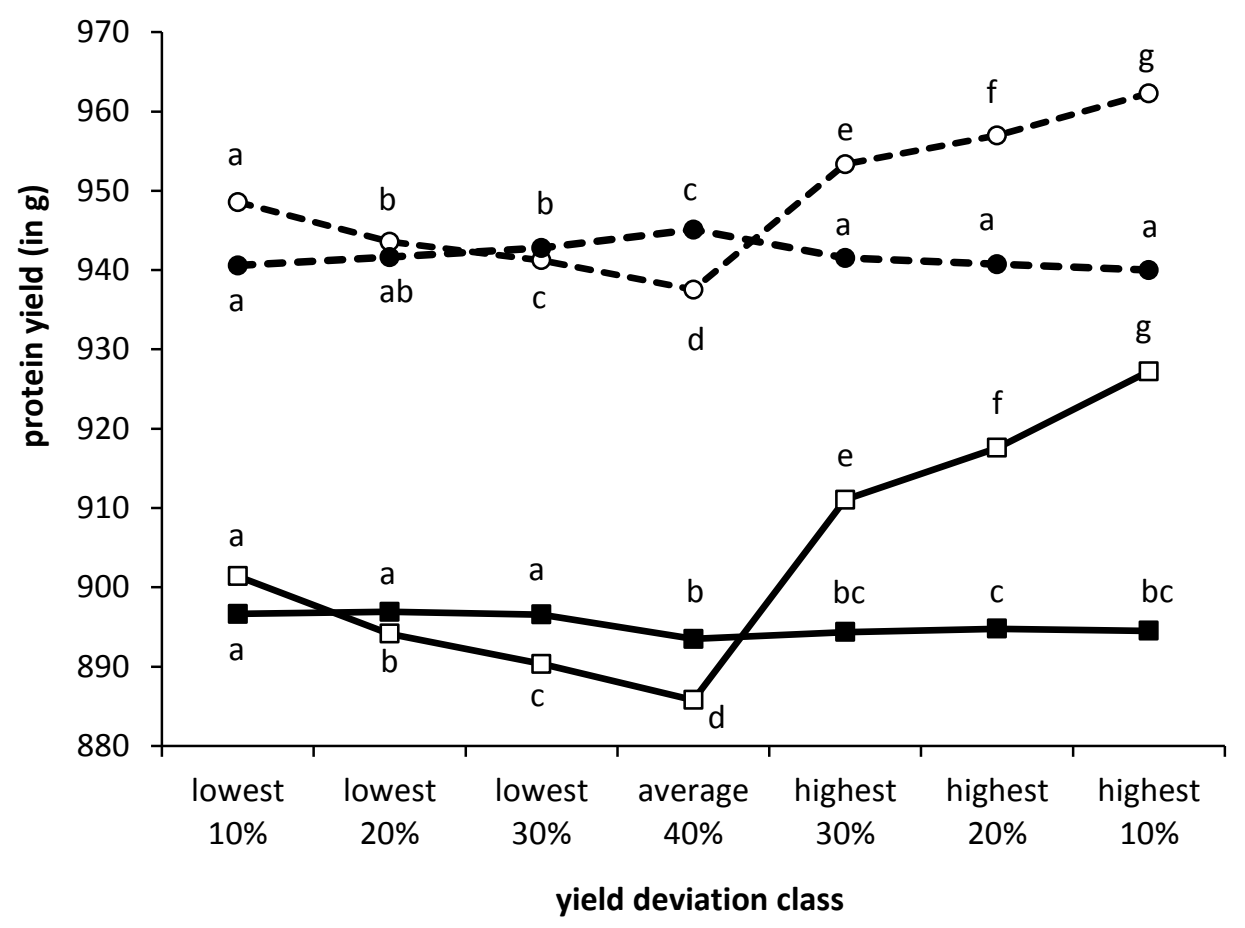

$\rightarrow-$ West-Protein $\quad-\infty-$ - East-Protein $\rightarrow$ West-SCS $\rightarrow-$ East-SCS

Figure 2. Mean herd-calving year parameters for test day protein yield stratified by region for different yield deviation classes ranked by YD for protein yield and by YD for somatic cell score (SCS).

Different superscripts indicate significant differences at $P<0.05$ within each region and trait combination. 


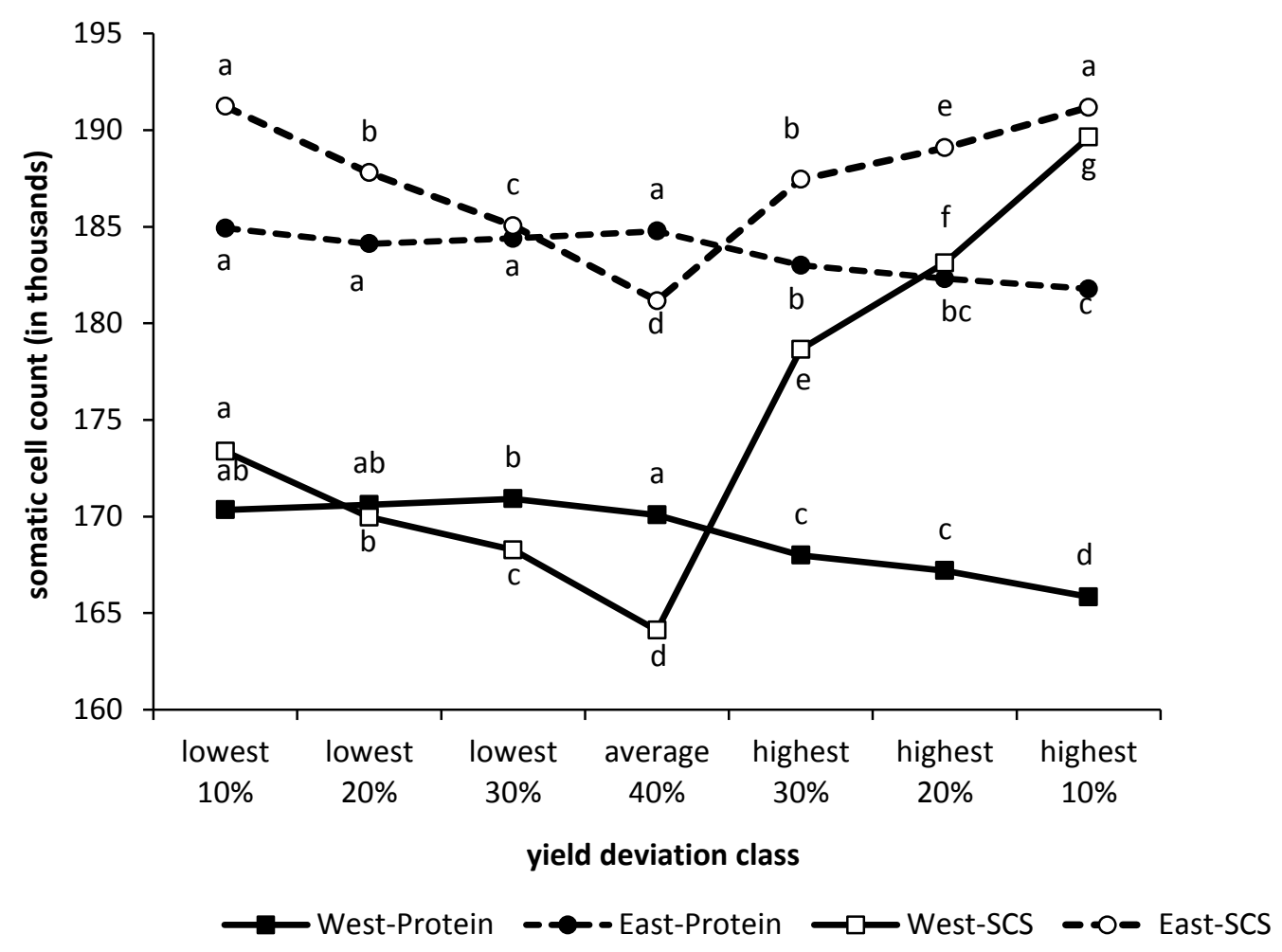

Figure 3. Mean herd-calving year parameters for somatic cell count stratified by region for different yield deviation classes ranked by YD for protein yield and by YD for somatic cell score (SCS). Different superscripts indicate significant differences at $\mathrm{P}<0.05$ within each region and trait combination. 


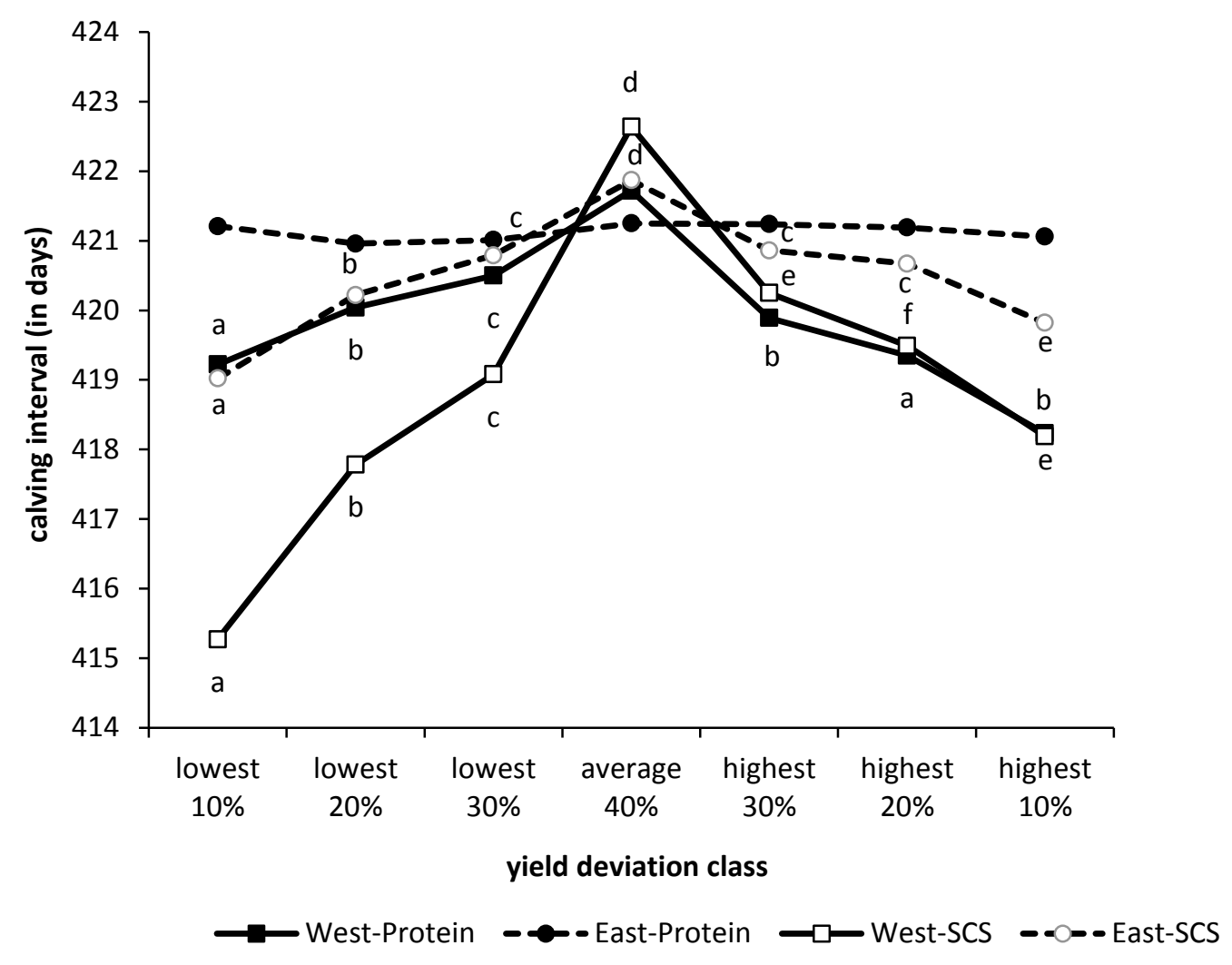

Figure 4. Mean herd-calving year parameters for calving interval stratified by region for different yield deviation classes ranked by YD for protein yield and by YD for somatic cell score (SCS). Different superscripts indicate significant differences at $\mathrm{P}<0.05$ within each region and trait combination. No significant differences $(P<0.05)$ were found within East-Protein. 


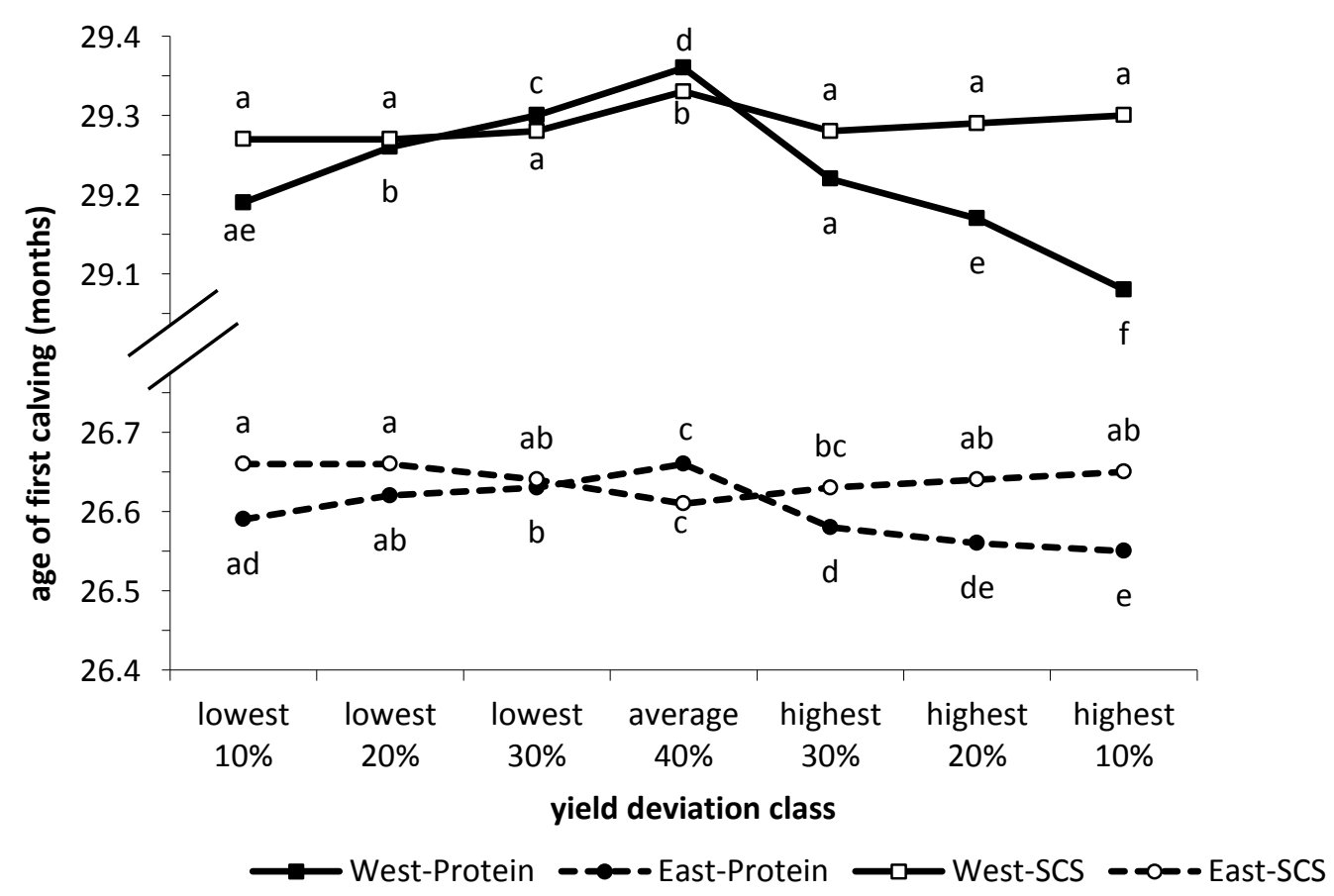

Figure 5. Mean herd-calving year parameters for age of first calving stratified by region for different yield deviation classes ranked by YD for protein yield and by YD for somatic cell score (SCS). Different superscripts indicate significant differences at $\mathrm{P}<0.05$ within each region and trait combination.

When ranking daughters according to YD for protein yield within sire, high YD were generally associated with a higher $\mathrm{HCY}$ production level for protein yield. This finding is also in line with the biological nature of traits, i.e. a positive association between the mean of the trait and the variance: a topic that has been investigated in dairy cattle from the perspective of heterogeneous intra-herd variances and selection proportions (e.g. Dong and Mao, 1988; Boldman and Freeman, 1990). High YD for protein yield were also found for a lower somatic cell count, and a lower AFC within herds. We also observed a decrease in the HCY calving interval in West Germany with a more stringent allocation of YD, whereas no significant differences were found in East Germany. Cows with negative daughter contributions (i.e. YD classes "lowest $30 \%$ ", "lowest $20 \%$ ", and "lowest 10\%") were allocated to $\mathrm{HCY}$ characterized by a higher production level, a lower AFC, and a shorter calving interval compared to the YD group representing less extremes in YD 
(average 40\%). Daughters characterized by average genetic contributions were generally kept in herds having a low production level for protein yield, and a late AFC. A low production level in combination with a high AFC, a long calving interval, and a high somatic cell count indicates a suboptimal management in those herds (Gernand et al., 2007). Similar trends were found when ranking daughters within sire according to $Y D$ for fat yield or $Y D$ for milk yield (results not shown). Hence, these results are in line with results from previous studies using an approach based on variance components (e.g. Dodenhoff and Swalve, 1998; König et al., 2005a; Gerber et al., 2008); i.e., the better the testing environment, the better the phenotypic expression of the genetic potential.

When ranking daughters according to YD for somatic cell score within sire, results from association analyses were completely different. Herd-calving year production level for test day protein yield, test day somatic cell count, and $\mathrm{HCY}$ age of first calving were relatively equal for all created YD classes. Only HCY somatic cell count was substantially higher for the lowest and the highest YD classes. Results for YD-SCS grouping showed the same patterns for East and for West Germany. Apparently, the genetic potential for somatic cell count being an indicator of mastitis resistance is better expressed in an environment where the cows' immune system is under challenge. This is a desired effect in terms of a more accurate genetic differentiation for somatic cell count and closely related susceptibility to mastitis (Philipsson et al., 1995), but difficult to combine with a maximization in genetic differentiation for production traits.

\section{Selection of cooperator herds}

Table 3 depicts average herd characteristics for the number of cows in first parity, test day protein yield, intra-herd SD for the production index RZM, and AFC stratified by region and herd quartiles based on the rank of the herd for YD in protein yield. In West Germany, herd size was relatively equal for the first three herd quartiles, but herds allocated to the fourth quartile were substantially smaller. Test day protein yield and intra-herd-SD of RZM decreased from the first to the fourth quartile. Cows in the first quartile produced at average $100 \mathrm{~g}$ protein per day higher than cows in the fourth 
quartile. The difference in intra-herd SD for RZM was 2.05 points when comparing these two quartiles. The second quartile was characterized by the lowest AFC, while the fourth quartile showed the highest AFC. Herd sizes, protein yield and intra-herd SD in RZM were higher, and AFC was lower for herd quartiles in East Germany when comparing to the respective quartiles in West Germany. Interestingly, herds in East Germany allocated to the first quartile were smaller than the herds in the second and third quartile, but substantially larger than herds in the fourth quartile. Apart from that, trends for average protein yield and intra-herd SD were similar to those in West Germany. Herds in the first quartile had the highest average protein yield, the highest SD in RZM, and the second lowest AFC. These results support former arguments that potential cooperator herds for PT should have a high production level combined with a high intra-herd variance and a low AFC (Gernand et al., 2007). An early AFC combines several desired effects for improvements in breeding programs, i.e. a distinct genetic differentiation, and additionally a decrease in generation intervals on the cow sire path of selection. 
Table 3. Mean herd characteristics and standard deviations (SD) for number of cows in first parity, test day protein yield, intra-herd standard deviation (Intra-herd-SD) in the German production index RZM, and age of first calving stratified by region for different herd quartiles ${ }^{1}$ according to YD selection for protein yield. Different superscripts within regions indicate significant differences at $\mathrm{P}<0.05$.

Herd characteristics

\begin{tabular}{|c|c|c|c|c|c|c|c|c|c|c|}
\hline \multirow[t]{2}{*}{ egion } & \multirow[t]{2}{*}{ Quartile } & \multirow[t]{2}{*}{$\begin{array}{l}{ }^{1} \text { No. of } \\
\text { herds }\end{array}$} & \multicolumn{2}{|c|}{$\begin{array}{l}\text { No. of cows in } \\
\text { first parity }\end{array}$} & \multicolumn{2}{|c|}{ protein (in g) } & \multicolumn{2}{|c|}{$\begin{array}{l}\text { Intra-herd- } \\
\text { SD for RZM }\end{array}$} & \multicolumn{2}{|c|}{$\begin{array}{l}\text { Age at first } \\
\text { calving }\end{array}$} \\
\hline & & & Mean & SD & Mean & SD & Mean & SD & Mean & SD \\
\hline \multirow{4}{*}{$\begin{array}{c}\text { West } \\
\text { Germ } \\
\text { any }\end{array}$} & 1 & 10 & $24.68^{a}$ & 11.07 & 0 & 73.98 & 11.00 & 1.18 & $29.10^{\mathrm{ab}}$ & \\
\hline & $2^{\text {nd }}$ & 610 & $25.31^{a}$ & 12.32 & $920.73^{b}$ & 74.52 & $10.99^{b}$ & 1.10 & $28.96^{\mathrm{a}}$ & 2.14 \\
\hline & $3^{\text {rd }}$ & 10 & $24.40^{\mathrm{a}}$ & 13.04 & $904.27^{\circ}$ & 77.28 & $10.58^{\mathrm{c}}$ & 1.23 & $29.32^{b}$ & 2.27 \\
\hline & $4^{\text {th }}$ & 11 & $18.32^{\mathrm{b}}$ & 7.73 & 844 & 97.54 & $9.55^{d}$ & 1.40 & $29.82^{b}$ & 2.50 \\
\hline \multirow{4}{*}{$\begin{array}{c}\text { East } \\
\text { Germ } \\
\text { any }\end{array}$} & $1^{\text {st }}$ & 126 & $82.62^{a}$ & 73.92 & $981.24^{\mathrm{a}}$ & 78.00 & $12.41^{a}$ & 1.09 & $26.67^{a}$ & 1.41 \\
\hline & $2^{\text {nd }}$ & 127 & b & 100.99 & $950.99^{b}$ & 66.48 & $11.95^{b}$ & 0.85 & $26.53^{\mathrm{a}}$ & 1.66 \\
\hline & $3^{\text {rd }}$ & 127 & $100.20^{\mathrm{ab}}$ & 102.29 & $912.13^{c}$ & 63.69 & $11.67^{c}$ & 0.89 & $26.72^{\mathrm{a}}$ & 1.45 \\
\hline & $4^{\text {th }}$ & 127 & $49.41^{\mathrm{c}}$ & 61.25 & $848.36^{d}$ & 94.62 & $10.30^{d}$ & 1.07 & $27.97^{b}$ & 1.6 \\
\hline
\end{tabular}

${ }^{7}$ Quartiles based on the rank of the herd for genetic differentiation. The higher the quartile, the lower the genetic differentiation in herds based on yield deviations.

Progeny testing in extremely large herds may have some logistic advantages (e.g. an easier coordination of PT especially in terms of conformation classification, or DNA sampling for genotyping in the near future), but a restriction only on herd size does not necessarily maximize genetic differentiation. Of course, a minimum for herd size should be a criterion to ensure a sufficient number of cows in contemporary groups with respect to a reliable genetic evaluation. 


\section{Rank correlations between different herd rankings}

Herd ranking based on YD for milk yield instead of YD for protein yield revealed almost identical results. The Spearman rank correlations between both alternatives were 0.84 and 0.86 for West and East Germany, respectively (Figure 6). Correlations between herd ranks for protein yield and those for fat yield were 0.64 for West Germany, and 0.69 for East Germany. However, correlations between herd ranks for protein yield and herd ranks for SCS were only 0.09 for West Germany, and slightly negative $(-0.05)$ for East Germany.

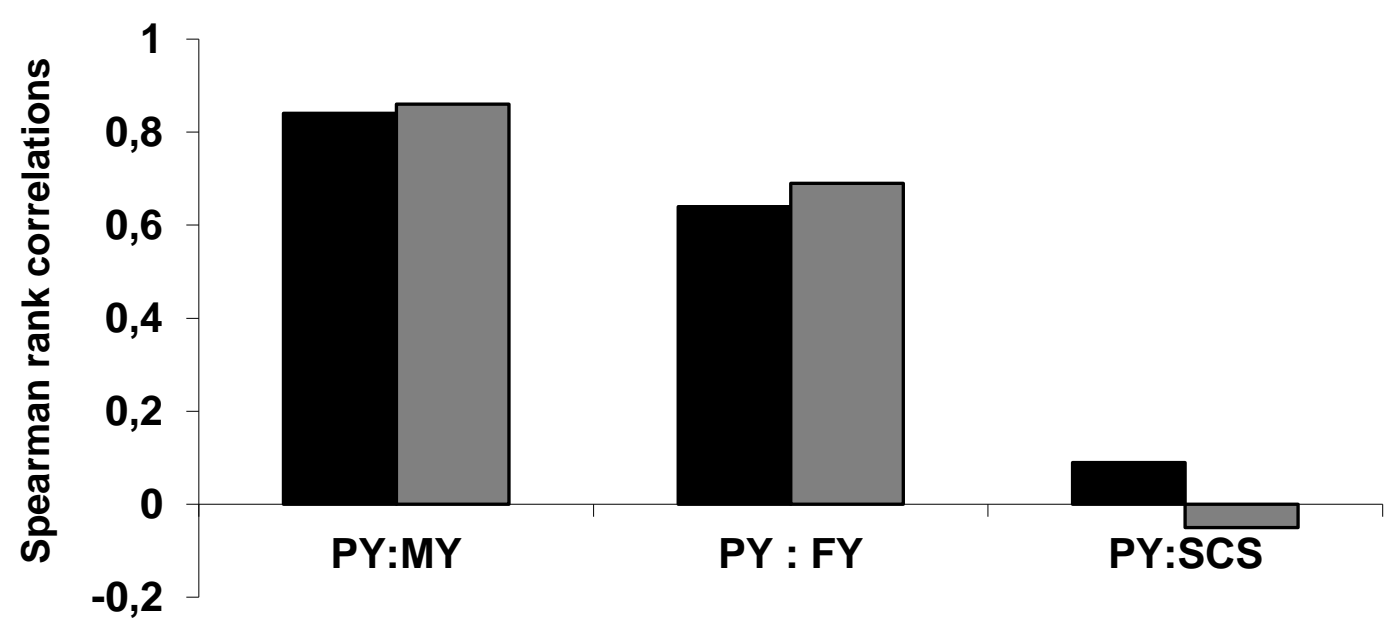

-West Germany $\quad \square$ East Germany

Figure 6. Spearman rank correlations between herd rank for protein yield (PY) and herd ranks for milk yield (MY), fat yield (FY) and somatic cell score (SCS) for two different regions in Germany

Additionally, Spearman rank correlations between the herd rank for YD in protein yield in calving year 2006 and the average herd rank from all calving years (2003-2007) were calculated. Year 2006 was the most recent calving year including a substantial data pool, while data from calving year 2007 was substantially reduced due to the criteria for publishing YD (Liu et al., 2004). Correlations were 0.65 for West Germany and 0.62 for East Germany. Those estimates of correlations suggest that an informative herd for a specific calving year will also be an informative herd in other calving years. Correlations between single years were in the range of 0.19 and 0.45 with correlations between consecutive years being higher than those between 
non-consecutive years. Possible reasons for differences in herd rankings in different year are changes in farm management, disease issues, heat stress, or poor quality of roughage in some specific years so that animals cannot express their full genetic potential. However, from the practical and logistic point of view, we do not recommend an update in selection of cooperator herds in short intervals, or a herd selection based only on the information of one specific $\mathrm{HCY}$.

\section{Analysis of genotype by environment interactions}

Daughters of young bulls are supposed to be randomly distributed within the test region of an Al station. Hence, daughters are randomly distributed across herd sizes and production levels. Consequently, EBVs of bulls should be unaffected by herd characteristics (Vinson, 1987). A shift towards selective PT in those herds with higher intra-herd variances and a superior herd management, the question of GXE will arise. Genotype by environment interaction occurs when different genotypes are not equally affected by different environments (Falconer, 1952), and can result in differences in the ranking of genotypes. Thus, rank correlations between average DYD for protein yield and SCS in upper and lower herd quartile for West and East Germany were calculated. Correlations coefficients are shown in Table 4. For protein yield, rank correlations ranged between 0.82 and 0.87 within and across different regions. Rank correlations for SCS between different quartiles ranged between 0.67 and 0.83 . Rank correlations including only those sires with more than 50 daughters between herd quartiles within the same region and also across different regions were in a range between 0.92 and 0.98 for both traits. Hence, according to the criteria suggested by Robertson (1959), correlations did not reveal any relevant GxE interaction between different herd conditions or regions. Results were also in line with those from Gerber et al. (2008), who found rank correlations in the range of 0.90 when comparing DYD of bulls in high input and low input production systems.

Several studies have focused on GxE (e.g. Van Vleck, 1963; Carabano et al., 1990; Hayes et al., 2003). König et al. (2005a) estimated genetic correlations for production traits between small herds from West Germany and herds from 
East Germany to be 0.90 and higher. Only when small family farms in West Germany were compared to large scale dairy farms in East Germany with more than 150 cows in first lactation, correlations dropped to 0.79 .

Economic pressure also will force dairy farmers in West Germany to increase herd size. Based on the genetic correlations above 0.95 estimated in this study, and considering the expected future herd structures in Germany, GxE should not be a problem. Currently selected cooperator herds for PT will be representative of the typical structure of German dairy cattle herds being competitive in the future.

Table 4. Spearman Rank correlations between average daughter yield deviations in the $1^{\text {st }}$ and $4^{\text {th }}$ herd quartile ${ }^{1}$ for potential cooperator herds in two different German regions

All sires Sires with at least 50 daughters

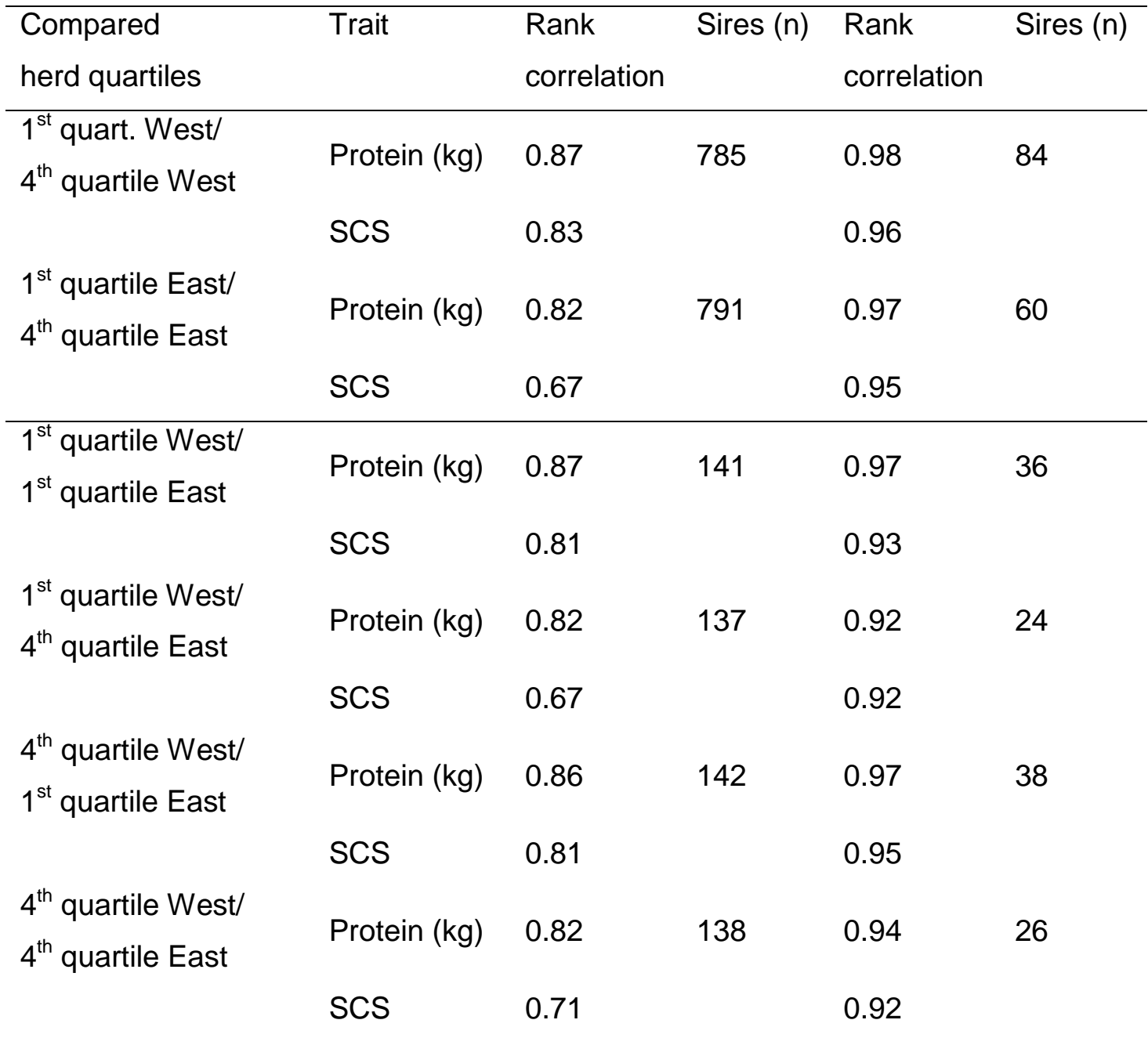

${ }^{1}$ Quartiles based on the rank of the herd for genetic differentiation. The higher the quartile, the lower the genetic differentiation in herds based on yield deviations 


\section{Practical considerations when implementing cooperator herds}

Using YD to identify informative cooperator herds for an accurate genetic differentiation among young bulls in PT schemes has three major advantages compared to selection strategies based on the intra-herd estimation of variance components (Brügemann, 2008; Dechow et al., 2008a). Firstly, computing time for the suggested method is substantially lower. Secondly, YD are generally available when computing EBVs in the process of national genetic evaluation. Hence, our algorithm could be incorporated as an additional feature in this routine process. Thirdly, the YD-based approach is applicable also to small herds as prevalent in West Germany. In contrast, an intra-herd variance component estimation approach leads to inflated standard errors of estimates with decreasing herd size. The proposed method is also characterized by a high flexibility to data restrictions, e.g. focusing only on herds using a high quantity of young sires, or for created subsets within distinct regions.

Gernand et al. (2007) suggested a two-step cluster approach to combine herd characteristics such as herd size, protein yield, and AFC for a selection of cooperator herds. This may be an applicable method, but it does not focus in detail on the aspect of optimizing genetic differentiation. Dechow and Norman (2007) used regression techniques to estimate herd-heritabilities more rapidly. Those estimates were moderately correlated with heritabilities estimated with an animal model. The regression technique can be seen as an alternative to stratify individual herds by heritability or additive genetic variance (Dechow et al., 2008b).

An adjustment procedure for heterogeneous variances (Reents et al., 1998) has been implemented in the estimation procedure of German EBV, which might have a slight impact on associations found between genetic contributions and herd characteristics. However, as the adjustment method depends on herd size, it will have a marginal impact only on the results for small herds as prevalent in West Germany.

Cooperator herds will be of major importance in the near future. Especially in the period of genome-wide selection (Meuwissen et al., 2001), program designs of existing breeding programs will be modified intensively. Schaeffer 
(2006) suggested using daughter records from cooperator herds as a substantial base to estimate SNP effects. Such a strategy especially is recommended for low heritability traits to ensure sufficient reliabilities of genomic breeding values (VanRaden et al., 2009). Several functional low heritability traits have been incorporated in international breeding goals (Mark, 2004; Miglior et al., 2005). Additional traits such as claw health (König and Swalve, 2006), pathogen-specific mastitis resistance (De Haas et al., 2002; Sørensen et al., 2009), or other metabolic and reproductive diseases (Zwald et al., 2004) might become important in the future. For achieving high reliabilities of EBVs in those low heritability traits, larger numbers of daughters and larger contemporary groups are required, as compared to production traits (Lindhé and Philipsson, 1998; Willam et al., 2002). To date, recording systems for these major health problems are not implemented in Germany. In contrast, in Scandinavia veterinary treatments are monitored on health cards by veterinarians (Philipsson and Lindhé, 2003). When starting such an attempt, it would be easier to concentrate on a certain amount of cooperator herds. Testing bulls in special cooperator herds and contracting farmers also will secure sufficient test capacities and reduce costs for logistics, e.g. for type trait classification (Swalve and König, 2007).

There is one, however minor, disadvantage of our strategy in the current situation: Selected contract herds based on yield traits are not necessarily the best herds for the genetic differentiation for SCS. We recommend a strategy that allows an accurate genetic differentiation for production traits, and using those informative and well managed herds to generate an extensive high quality data pool for functional health traits. When selecting cooperator herds with a high health status (e.g. low somatic cell count), the disadvantage of reduced YD differentiation for SCC may be compensated for by recording mastitis. Genetic gain for animal health generally will increase when using direct health information compared to selection strategies focusing on indicator traits recorded in the entire population (Philipsson, 1995; De Haas et al., 2002; König et al., 2005b). Another strategy to ensure an adequate within-herd variation in health traits would be to maintain a certain amount of herds in progeny testing that are characterized by only 
average herd ranks combined with more challenging environments like a higher average SCC.

\section{Conclusions}

The strategy to identify herds with maximized genetic differentiation based on YD is a practical method for selecting cooperator herds in dairy cattle breeding programs. In contrast to other herd selection procedures such as the estimation of intra-herd heritabilities, the YD approach is relatively easy to implement, requires less computing time, and is practicable even in the case of small herd sizes. However, the applied theoretical selection strategy for finding cooperator herds implies that farmers are willing to participate in such a system. Financial compensation for participating farmers is necessary, especially when focusing on the accurate recording of additional and new health traits in cooperator herds. Ultimately, the presented approach can be seen as a substantial contribution to the design of competitive and sustainable dairy cattle breeding programs.

\section{Acknowledgements}

The authors appreciate funding from the Lower Saxon Ministry of Food, Agriculture, Consumer Protection and Regional Development.

\section{References}

Boichard, D., B. Bonaiti, A. Barbat, and S. Mattalia. 1995. Three methods to validate the estimation of genetic trend for dairy cattle. J. Dairy Sci. 78:431-437.

Boldman, K. G. and A. E. Freeman. 1990. Adjustment for heterogeneity of variances by herd production level in dairy cow and sire evaluation. J. Dairy Sci. 73:503-512.

Brügemann, K. 2008. Untersuchungen zur Heterogenität der Varianzen von Merkmalen der Milchleistung unter differenzierter Stratifikation des Gesamtmaterials beim Holsteinrind in Deutschland.University of Halle. $\mathrm{PhD}$ thesis. 
Carabano, M. J., K. M. Wade, and L. D. Van Vleck. 1990. Genotype by environment interactions for milk and fat production across regions of the United States. J. Dairy Sci. 73:173-180.

De Haas, Y., H. W. Barkema, and R. F. Veerkamp. 2002. Genetic parameters of pathogen-specific incidence of clinical mastitis in dairy cows. Anim. Sci. 74:233-242.

Dechow, C. D. and H. D. Norman. 2007. Within-herd heritability estimated with daughter-parent regression for yield and somatic cell score. J. Dairy Sci. 90:482-492.

Dechow, C. D., H. D. Norman, N. R. Zwald, C. M. Cowan, and O. M. Meland. 2008a. Relationship between individual herd-heritability estimates and sire misidentification rate. J. Dairy Sci. 91:1640-1647.

Dechow, C. D., H. D. Norman, and C. A. Pelensky. 2008b. Short communication: Variance estimates among herds stratified by individual herd heritability. J. Dairy Sci. 91:1648-1651.

Dekkers, J. C. M., G. E. Vandervoort, and E. B. Burnside. 1996. Optimal size of progeny groups for progeny-testing programs by artificial insemination firms. J. Dairy Sci. 79:2056-2070.

Dodenhoff, J. and H. H. Swalve. 1998. Heterogeneity of variances across regions of northern Germany and adjustment in genetic evaluation. Livest. Prod. Sci. 53:225-236.

Dong, M. C., and I. L. Mao. 1988. Interaction between sire and level of intraherd production variance. J. Dairy Sci. 65 (suppl. 1): 100. (Abstr.).

Falconer, D. S. 1952. The problem of environment and selection. Am. Nat. 86:293-298.

Garrick, D. J. and L. D. Van Vleck. 1987. Aspects of selection for performance in several environments with heterogeneous variances. J. Anim Sci. 65:409-421.

Gerber, A., D. Krogmeier, R. Emmerling, and K.-U. Götz. 2008. Analysis of genotype by environment interaction for milk yield traits in first lactation of Simmental cattle. J. Anim. Breed. Genet. 125:382-389.

Gernand, E., R. Wassmuth, U. U. von Borstel, and S. König. 2007. Heterogeneity of variance components for production traits in large-scale dairy farms. Livest. Sci. 112:78-89. 
Hammond, J. 1947. Animal breeding in relation to nutrition and environmental conditions. Biol. Rev. 22:195-213.

Hayes, B. J., M. Carrick, P. Bowman, and M. E. Goddard. 2003. Genotype X environment interaction for milk production of daughters of Australian dairy sires from test-day records. J. Dairy Sci. 86:3736-3744.

Henderson, C. R. 1964. Selecting the young sire to sample in artificial insemination. J. Dairy Sci. 47:439-441.

Hill, W. G. 1984. On selection among groups with heterogeneous variance. Anim. Prod. Sci. 39:473-477.

König, S., G. Dietl, I. Raeder, and H. H. Swalve. 2005a. Genetic relationships for dairy performance between large-scale and small-scale farm conditions. J. Dairy Sci. 88:4087-4096.

König, S., A. R. Sharifi, H. Wentrot, D. Landmann, M. Eise, and H. Simianer. 2005b. Genetic parameters of claw and foot disorders estimated with logistic models. J. Dairy Sci. 88:3316-3325.

König, S. and H. H. Swalve. 2006. A model calculation on the prospects of an improvement of claw health in dairy cattle via genetic selection. Züchtungskunde 78:345 - 356.

König, S., S. Lessner, and H. Simianer. 2007. Application of controlling instruments for improvements in cow sire selection. J. Dairy Sci. 90:19671980.

König, S., K. Brüggemann, H. Simianer, and H. H. Swalve. 2008: Test herds in dairy cattle breeding programmes 2 nd communication: Strategies for finding test herds. Züchtungskunde, 80(2):114-126

Lindhé, B. and J. Philipsson. 1998. Genetic correlations between production with disease resistance and fertility in dairy cattle and consequences for total merit selection. Acta Agric. Scand. 48:216 - 221.

Liu, Z., F. Reinhardt, A. Bünger, and R. Reents. 2004. Derivation and calculation of approximate reliabilities and daughter yield-deviations of a random regression test-day model for genetic evaluation of dairy cattle. J. Dairy Sci. 87:1896-1907.

Mark, T. 2004. Applied genetic evaluations for production and functional traits in dairy cattle. J. Dairy Sci. 87:2641-2652. 
Meinert, T. R., H. D. Norman, J. M. Mattison, and C. G. Sattler. 1997. Usability for genetic evaluations of records from herds participating in progeny test programs of artificial insemination organizations. J. Dairy Sci. 80:2599-2605.

Meuwissen, T. H. E., B. J. Hayes, and M. E. Goddard. 2001. Prediction of total genetic value using genome-wide dense marker maps. Genetics 157:1819-1829.

Miglior, F., B. L. Muir, and B. J. Van Doormaal. 2005. Selection indices in Holstein cattle of various countries. J. Dairy Sci. 88:1255-1263.

Mrode, R. A. and G. J. T. Swanson. 2004. Calculating cow and daughter yield deviations and partitioning of genetic evaluations under a random regression model. Livest. Prod. Sci. 86:253-260.

Neuner, S., R. Emmerling, G. Thaller, and K.-U. Gotz. 2008. Strategies for estimating genetic parameters in marker-assisted best linear unbiased predictor models in dairy cattle. J. Dairy Sci. 91:4344-4354.

Padilla, D. and J. F. Keown. 1990. Variances in herd production due to different management practices. J. Anim. Sci. 68 (Suppl. 1):70-71.

Philipsson, J. 1995. Züchtung auf Gesundheit am Beispiel Skandinavien erfolgreiche Kooperation von Landwirt, Tierarzt, MLP und Zuchtorganisation. Züchtungskunde 67:454-460.

Philipsson, J. and B. Lindhé. 2003. Experiences of including reproduction and health traits in Scandinavian dairy cattle breeding programmes. Livest. Prod. Sci. 83:99-112.

Philipsson, J., G. Ral, and B. Berglund. 1995. Somatic cell count as a selection criterion for mastitis resistance in dairy cattle. Livestock Production Science 41:195-200.

Powell, R. L., G. R. Wiggans, and H. D. Norman. 1994. Effect of sampling status and adjustment for heterogeneous variance on bias in bull evaluations. J. Dairy Sci. 77:883-890.

Reents, R., L. Dopp, M. Schmutz, and F. Reinhardt. 1998. Impact of application of a test-day model to dairy production traits on genetic evaluation of cows. Interbull Bull. 17:49-54.

Robertson, A. 1959. The sampling variance of the genetic correlation coefficient. Biometrics 15:469-485. 
Schaeffer, L. R. 2006. Strategy for applying genome-wide selection in dairy cattle. J. Anim. Breed. Genet. 123:218-223.

Short, T. H., R. W. Blake, R. L. Quaas, and L. D. Van Vleck. 1990. Heterogeneous within-herd variance. 1. Genetic parameters for first and second lactation milk yields of grade Holstein cows. J. Dairy Sci. 73:33123320.

Skjervold, H. and H. J. Langholz. 1964. Factors affecting the optimum structure of Al breeding in dairy cattle. Zeitschr. Tierz. u. Züchtungsbiolol. 80:25-40.

Sørensen, L. P., P. Madsen, T. Mark, and M. S. Lund. 2009. Genetic parameters for pathogen-specific mastitis resistance in Danish Holstein Cattle. animal 3:647-656.

Swalve, H. H. and S. König. 2007. Test herds in dairy cattle breeding programmes - 1st communication: General considerations.

Züchtungskunde 79:249-262.

Szyda, J., Z. Liu, F. Reinhardt, and R. Reents. 2005. Estimation of quantitative trait loci parameters for milk production traits in German Holstein dairy cattle population. J. Dairy Sci. 88:356-367.

Van Vleck, L. D. 1963. Genotype and environment in sire evaluation. J. Dairy Sci. 46:983-987.

VanRaden, P. M., C. P. Van Tassell, G. R. Wiggans, T. S. Sonstegard, R. D. Schnabel, J. F. Taylor, and F. S. Schenkel. 2009. Invited Review: Reliability of genomic predictions for North American Holstein bulls. J. Dairy Sci. 92:16-24.

VanRaden, P. M. and G. R. Wiggans. 1991. Derivation, calculation, and use of national animal model information. J. Dairy Sci. 74:2737-2746.

Vierhout, C. N., B. G. Cassell, and R. E. Pearson. 1999. Comparisons of cows and herds in two progeny testing programs and two corresponding states. J. Dairy Sci. 82:822-828.

Vinson, W. E. 1987. Potential bias in genetic evaluations from differences in variation within herds. J. Dairy Sci. 70:2450-2455.

Weigel, K. A., D. Gianola, B. S. Yandell, and J. F. Keown. 1993. Identification of factors causing heterogeneous within-herd variance components using a structural model for variances. J. Dairy Sci. 76:1466-1478. 
Willam, A., C. Egger-Danner, J. Solkner, and E. Gierzinger. 2002.

Optimization of progeny testing schemes when functional traits play an important role in the total merit index. Livest. Prod. Sci. 77:217-225.

Zwald, N. R., K. A. Weigel, Y. M. Chang, R. D. Welper, and J. S. Clay. 2004. Genetic selection for health traits using producer-recorded data. I. Incidence rates, heritability estimates, and sire breeding values. J. Dairy Sci. 87:4287-4294. 


\section{$4^{\text {th }}$ Chapter}

\section{Controlling Inbreeding and Maximizing Genetic Gain using Semi-definite Programming with Pedigree Based and Genomic Relationships}

S. Schierenbeck, ${ }^{\star \dagger}$ E.C.G. Pimentel, ${ }^{\#}$ M. Tietze, ${ }^{\star}$, J. Körte,${ }^{\ddagger}$ R. Reents, ${ }^{\dagger}$ F. Reinhardt $^{\dagger}$, H. Simianer ${ }^{\star}$ and S. König,,

*Animal Breeding and Genetics Group, Department of Animal Sciences, Georg-August-University of Göttingen, D-37075 Göttingen, Germany \#Department of Animal Breeding, University of Kassel, D-37213 Witzenhausen, Germany ${ }^{\ddagger}$ Institute for Animal Breeding and Husbandry, Christian-Albrechts-University of Kiel, D-24118 Kiel

†Vereinigte Informationssysteme Tierhaltung w.V., D-27283 Verden, Germany 


\section{Abstract}

Due to relatively high levels of genetic relationships among potential bull sires and bull dams, innovative selection tools should consider both genetic gain and genetic relationships in a long term perspective. Optimum genetic contribution (OGC) theory using official estimated breeding values for a moderately heritable trait (INDEX-PROD = production index), and a lowly heritable functional trait (INDEX-SCS= index for somatic cell score) was applied to find optimal allocations of bull dams and bull sires. In contrast to previous practical applications using optimizations based on Lagrange multipliers, we focussed on semi-definite programming (SDP). SDP methodology was either combined with pedigree $\left(a_{i j}\right)$ or genomic relationships $\left(f_{i j}\right)$ among selection candidates. Selection candidates were 484 genotyped bulls, and 499 pre-selected genotyped bull dams completing a central test on station. In different scenarios separately for PROD and SCS, constraints on the average pedigree relationships among future progeny were varied from $a_{i j}=0.08$ to $a_{i j}=0.20$ in increments of 0.01 . Corresponding constraints for SNP based kinship coefficients were derived from regression analysis. Applying the coefficient of 0.52 with an intercept of 0.14 estimated for the regression pedigree relationship on genomic relationship, the corresponding range to alter genomic relationships varied from from $f_{i j}=0.18$ to $f_{i j}=0.24$. Despite differences for some bulls in genomic and pedigree relationships, the same trends were observed for constraints on pedigree and corresponding genomic relationships regarding results in genetic gain and achieved coefficients of relationships. Generally, allowing higher values for relationships resulted in an increase of genetic gain for INDEX-PROD and INDEX-SCS, and in a reduction in the number of selected sires. Interestingly, more sires were selected for all scenarios when restricting genomic relationships, compared to restrictions on pedigree relationships. For example, at constraint of $f_{i j}=0.185$ and selection on INDEX-PROD, the number of selected sires was 35 . In contrast, only 21 sires were selected at the comparable constraint on additive-genetic relationship of $a_{i j}=0.09$. A further reduction in relationships is possible when using SDP output (i.e. suggested genetic contributions of selected parents), and applying a 
simulated annealing algorithm to define specific mating plans. However, the advantage of this strategy is limited to a short- term perspective, and probably not successful in the period of genomic selection allowing a substantial reduction of generation intervals.

\section{Introduction}

The methodology of genomic selection enables the estimation of genomic breeding values of young sires with relatively high accuracies for production as well as for functional traits (e.g. VanRaden et al., 2009). An expected consequence is a further increase of selection intensities in genomic breeding programs on the cow sire and on the bull sire pathways of selection. König et al. (2009) economically evaluated genomic breeding programs based on the general framework of a genomic breeding program design as developed by Schaeffer (2006). Gain in discounted profit was strongly correlated with the reduction in the number of young sires having been selected upon genomic breeding values. For example, when selecting 25 young sires per year to inseminate a population of 50,000 cows, discounted profit per cow and year was 50 Euro. Profit was doubled when increasing selection intensity and selecting only 5 outstanding young sires. Hence, to balance genetic gain and inbreeding in a long-term perspective in the genomic era, König et al. (2009) suggested to use genomic information (i.e. the SNP pattern and genomic EBV) and to focus on both aspects, selection response and constraints in relationships, among selection candidates.

The upward trend of the inbreeding level in different dairy cattle populations mainly due to the widespread distribution of sire semen has been already evaluated in several studies in the past 20 years (e.g. Wiggans et al., 1995; Miglior, 2000; Thompson et al. 2000; Kearny et al., 2004). Due to the effect of selection on phenotypic means, genetic variances, and changes in relationships of individuals to the population, VanRaden (2005) described a method for adjusting expected future inbreeding that can be included in the process of genetic evaluation. According to VanRaden (2005), this adjustment procedure has been introduced in several United States trait evaluations in February 2005. An approach used by König and Simianer (2006) to maximize genetic gain by restricting additive genetic relationships 
among bull sires and bull dams was based on quantitative genetics and optimum genetic contributions (OGC) as developed in theory by Meuwissen (1997). König and Simianer (2006) strongly recommended controlling inbreeding when mating bull sires to bull dams, because both genetic groups have substantial impact on the development of genetic relationships in dairy cattle breeding programs. Available mating programs used by breeding organizations or dairy cattle producers suggest cow sires for matings with cow dams. Such a mating strategy implies the management of inbreeding and relationships only in the short term. In contrast, long-term control of inbreeding in a dairy population requires consideration of relationships between young bulls entering $\mathrm{Al}$ progeny test programs, or directly selected sires for Al based on genomic breeding values. The program GENCONT (Meuwissen, 2002) was used by König and Simianer (2006) for elite matings in a breeding program embracing 30 young bulls per year to find the optimal allocations of bull sires and bull dams for one specific breeding organization. Compared with the actual breeding program applied in practice, OGC-theory revealed the potential to increase genetic gain under the same constraint for the increase of average relationship by $13.1 \%$.

Algorithms as implemented in GENCONT (Meuwissen, 2002) are based upon a series of relaxed optimizations using Lagrange multipliers. This methodology has been intensively discussed by Pong-Wong and Woolliams (2007), and they focussed on the problem that invalid negative genetic contributions could be assigned to some individuals. As an approximate solution, GENCONT fixes genetic contributions of those individuals to zero, and the algorithms continues in a smaller subset of selection candidates. An alternative suggested by Pong-Wong and Woolliams (2007) for maximizing genetic gain while restricting inbreeding is a method based upon semidefinite programming (SDP). Due to the failure of Lagrange multipliers in some situations, i.e. the possible negative contributions when applying GENCONT, expected gains with SDP for some examples were substantially higher in the range from $1.5 \%$ to $9 \%$.

Practical applications of OGC theory in dairy cattle are mainly based on GENCONT and used additive genetic relationship matrices among selection candidates (e.g. König and Simianer, 2006; Kearny et al., 2004). Additive 
genetic relationship matrices only use pedigree data to calculate probabilities that gene pairs are identical by descent (Wright, 1922). However, wrong and missing sire information for Holstein dairy cattle in the assumed range from $3 \%$ to $23 \%$ (e.g. Weller et al., 2004) is a well-known problem for setting up accurate additive genetic relationships. Further problems arise when applying BLUP animal or BLUP sire models, i.e. possibly biased estimated breeding values (EBV), especially for low heritability traits. Paternity errors are due to recording errors by the farmer or by the Al company (Sanders et al., 2006). Alternatively, the use of actual SNP-genotypes for construction of genomic relationship matrices can provide more accurate measures of realized relationships among animals. Pimentel et al. (2011a) estimated the association of kinship coefficients estimated from marker data against relationship coefficients estimated from pedigree data for genotyped bulls in Germany. The $\mathrm{R}^{2}$ value was only 0.53 . Accordingly, the authors suggested to use genomic relationships for further association analyses due to the potential sire and dam misidentification when using pedigree relationships. Furthermore, as pointed out by Schork (2001), relationship coefficients calculated from pedigree data do not take into account the variation in relationships among similarly related individuals. Such variation is accounted for when computing relationship coefficients using marker information. Consequently, the aim of our study was to generate a framework for the combination of SDP methodology with genomic relationships among selection candidates, and to determine optimal genetic contributions for elite mating schemes for the optimization of genomic breeding programs. When restricting selection of candidates according to genomic relationships, also realized additive genetic relationships were monitored, and vice versa. 


\section{Material and methods}

The data file of selection candidates consisted of 484 German Holstein bulls born in 2002 which were part of the German reference population for the estimation of SNP effects. Thus their estimated breeding values (EBV) were very similar to their genomic breeding values (GBV). All bulls were included without prior selection on EBV. Furthermore, 499 pre-selected potential bull dams born in the years 2001 to 2006 and located at a central station test were included in the data set. All selection candidates had been genotyped, and they had an official national EBV for the overall production index (INDEX-PROD), and for the somatic cell score index (INDEX-SCS). Means and standard deviations for both indices are shown in Table 1.

Table 1: Means, standard deviation (SD), minimum and maximum for the selection criteria production index (INDEX-PROD) and somatic cell score index (INDEX-SCS) for bull sires and bull dams

\begin{tabular}{lllllll}
\hline & & & \multicolumn{4}{c}{ Descriptive statistics } \\
& number & index & mean & SD & minimum & maximum \\
\hline cows & 499 & PROD & 103.27 & 6.61 & 81 & 121 \\
& & SCS & 103.24 & 8.60 & 79 & 126 \\
bulls & \multirow{2}{*}{484} & PROD & 103.15 & 12.26 & 65 & 141 \\
& & SCS & 102.23 & 11.15 & 67 & 136 \\
\hline
\end{tabular}

\section{Methods}

\section{Coefficients for relationship matrices.}

Coefficients of kinship among genotyped bull sires and bull dams were calculated following the similarity index approach proposed by Eding and Meuwissen (2001). For each SNP locus, a genetic similarity index between a pair of bulls $x$ and $y$ was computed as $S_{x y}=0.25\left(I_{11}+l_{12}+l_{21}+l_{22}\right)$, where $I_{i j}$ is 1 , if allele $\mathrm{i}$ in $\mathrm{x}$ is identical to allele $\mathrm{j}$ in $\mathrm{y}$, or 0 otherwise. Under the assumption of unique founder alleles $S_{x y}$ averaged over multiple loci is an unbiased estimator of the kinship coefficient (i.e., the probability of IBD). When founder 
alleles are not unique, it needs to be corrected for the probability of alleles being alike in state (AIS).

For a given locus, the kinship coefficient between a pair of animals $i$ and $j\left(f_{i j}\right)$ was therefore estimated as:

$$
\hat{f}_{i j}=\frac{S_{i j}-S}{1-S}
$$

where $s$ is the similarity index in the founder population, i.e., the probability of two alleles being AIS, but not IBD. An estimate of $s$ can be obtained from data on the founder population as:

$$
s=\sum q_{k}^{2}
$$

where $q_{k}$ is the frequency of the $k^{\text {th }}$ allele of the given locus in the founder population.

Allele frequencies in the founder population were estimated following the mixed model equations method proposed by Gengler et al. (2007) using a pedigree comprising 21,646 animals tracing back to 1906. Final estimates of kinship coefficients between every pair of animals were computed by averaging across all loci. Since estimates of $s$ differed from one locus to another, the inverse of the variance of the estimate was used as weight when taking the average, as proposed by Eding and Meuwissen (2001). Pedigree based relationships $a_{i j}$ were calculated by the tabular method (Emik and Terrill, 1949).

\section{SDP-algorithm}

Based on the SDP theory for maximizing genetic gain and minimizing long term inbreeding or relationships as introduced by Pong-Wong and Woolliams (2007), we developed an own computer program. The flexibility of this computer program allows using either pedigree based relationships or kinship coefficients derived from SNP data as an input file. The basic idea of the SDP algorithm originates from Fujisawa et al. (2002). Accounting for minimum contributions was done in an iterative way by fixing the maximum contribution of the animals with the lowest contributions to zero, and then starting the SDP algorithm again. This was done until all animals exceeded the minimum contribution.

The parameter file for the SDP algorithm to describe the outline of the breeding program was set up in the standard SDP form as described by 
Pong-Wong and Woolliams (2007). Minimum genetic contributions for bull sires were fixed at $2 \%$, and maximum genetic contributions for individual sires were restricted to $20 \%$, resulting in 10 possible matings. Genetic contributions for bull dams were generally fixed at $2 \%$. This implies an annually generated number of 50 young bulls, assuming that reproduction biotechnologies ensure at least one male offspring per cow and year. This is a realistic success rate of embryo transfer as used by Wensch-Dorendorf et al. (2011) to evaluate genomic dairy cattle breeding programs in Germany via simulation studies.

In different scenarios for INDEX-PROD and INDEX-SCS separately, constraints on the average pedigree relationships among future progeny were varied from $a_{i j}=0.08$ to $a_{i j}=0.20$ in increments of 0.01 . Corresponding constraints for SNP based kinship coefficients were derived from regression analysis. Using the regression coefficient for $b_{f_{i j, a j}}$ of 0.52 with an intercept of 0.14 produces a corresponding range in genomic relationships from $f_{i j}=0.18$ to $f_{i j}=0.24$ (Figure 1)

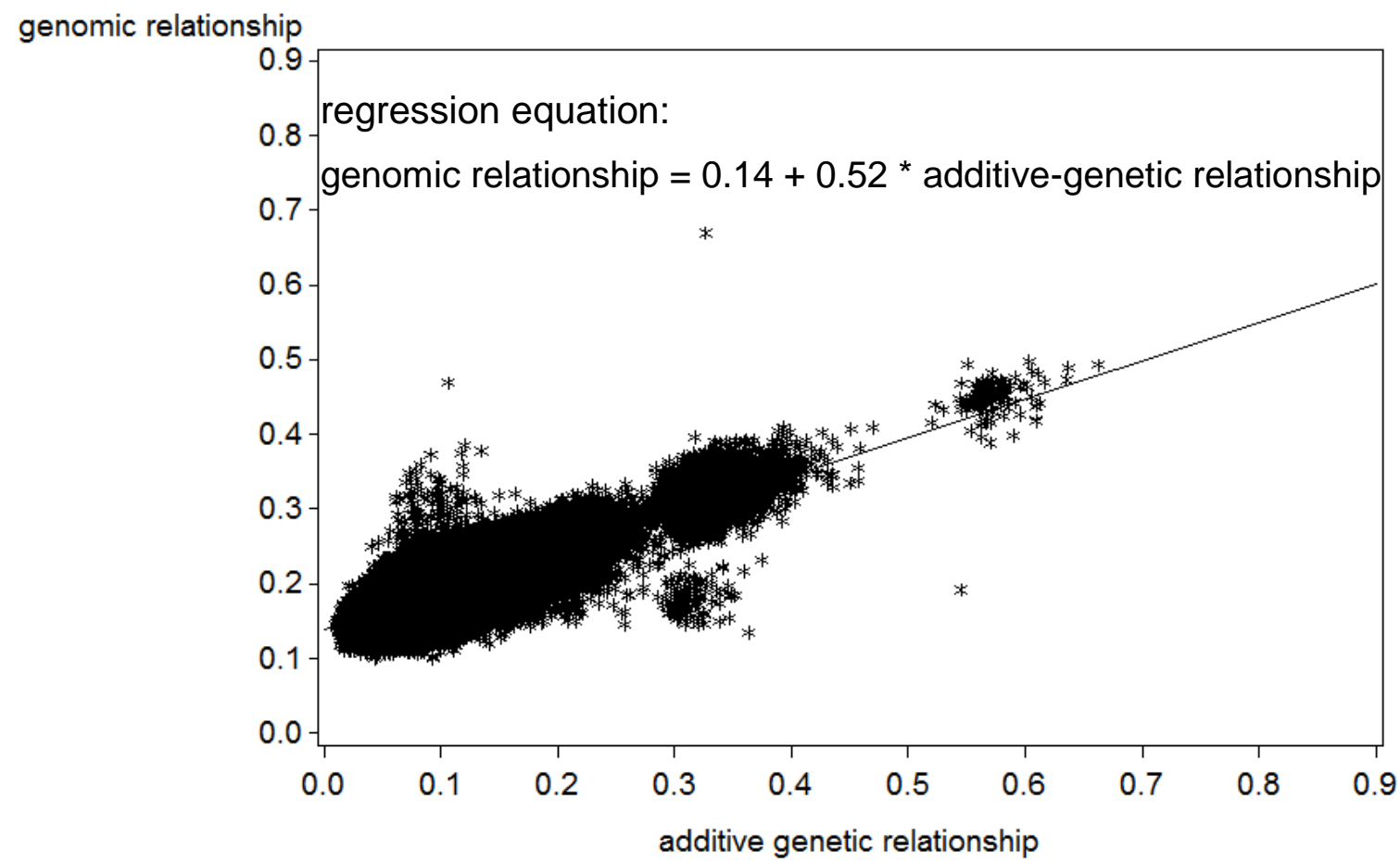

Figure 1. Relationship coefficients estimated from SNP- data (genomic relationship) against relationship coefficients estimated from pedigree data (additive genetic relationship) 


\section{Specific mating design}

SDP output, i.e. suggested genetic contributions for bull sires and bull dams, was used to identify specific matings with the ultimate goal to minimize the average inbreeding coefficient in the short term in the following generation. For this purpose, a simulated annealing algorithm was applied (Press et al., 1989; Sonesson and Meuwissen, 2000). The essential steps of this algorithm have been summarized by König et al. (2010). Further essential input parameters were all possible relationships between pairs of selected bull dams and selected bull sires. The annealing algorithm was applied to the SDP output from two constraints on additive genetic relationships, and from the corresponding two constraints on genomic relationships. Constraints were $a_{i j}=0.09$ and $a_{i j}=0.14$, and accordingly $f_{i j}=0.185$ and $f_{i j}=0.21$.

\section{Results and Discussion}

\section{SDP algorithm}

Average additive genetic relationship among 983 selection candidates was $0.098 \pm 0.040$, and average genomic relationship was $0.189 \pm 0.035$ (Table 2). Average relationships among potential bull dams, among potential bull sires, and among bull dams and bull sires are also shown in Table 2. Additive genetic relationships among the best 4000 index cows in 2006 originating from Great Britain, Italy and Ireland were 0.083, 0.087, and 0.107, respectively (Mrode et al., 2009), and thus comparable to results from our study.

Table 2: Average coefficients of relationship and standard deviations (SD) for selection candidates

\begin{tabular}{lrc}
\hline Selection candidates & $\begin{array}{c}\text { Additive genetic } \\
\text { relationship } \pm \text { SD }\end{array}$ & $\begin{array}{l}\text { Genomic } \\
\text { relationship } \pm \text { SD }\end{array}$ \\
\hline 484 bull sires & $0.105 \pm 0.045$ & $0.192 \pm 0.029$ \\
499 bull dams & $0.097 \pm 0.045$ & $0.189 \pm 0.030$ \\
983 bull sires and dams & $0.098 \pm 0.041$ & $0.190 \pm 0.035$ \\
484 bull sires with 499 bull & $0.095 \pm 0.035$ & $0.187 \pm 0.025$ \\
dams & & \\
\hline
\end{tabular}


Average values for both indices of selected animals for different constraints on additive genetic and genomic relationships are shown in Figure 2 (INDEXPROD) and in Figure 3 (INDEX-SCS). An increase in INDEX-PROD was generally associated with an increase in allowed long-term relationships. This is due to the fact that a relaxation in constraints for relationships resulted in a lower number of selected bulls (Figure 4). Hence, higher genetic contributions of genetically favourable single bulls were possible. These findings are in line with those of Kearney et al. (2004) and of König and Simianer (2006) when applying OGC as implemented in GENCONT. Also Weigel and Lin (2002) showed that an increase in allowed relationships decreased the number of selected sires. Kearney et al. (2004) associated genetic contributions and index scores for different levels of constraint on inbreeding for selected males, and they found a higher proportion of selected males with a more stringent constraint on rate of inbreeding. Interestingly, more sires were selected for all scenarios when restricting genomic relationships, compared to restrictions on pedigree relationships. For example at constraint of $f_{i j}=0.185$ and selection based on INDEX-PROD, the number of selected sires was 35. In contrast, only 21 sires have been selected at the comparable constraint on additive genetic relationship of $\mathrm{a}_{i j}=$ 0.09 (Figure 4). 


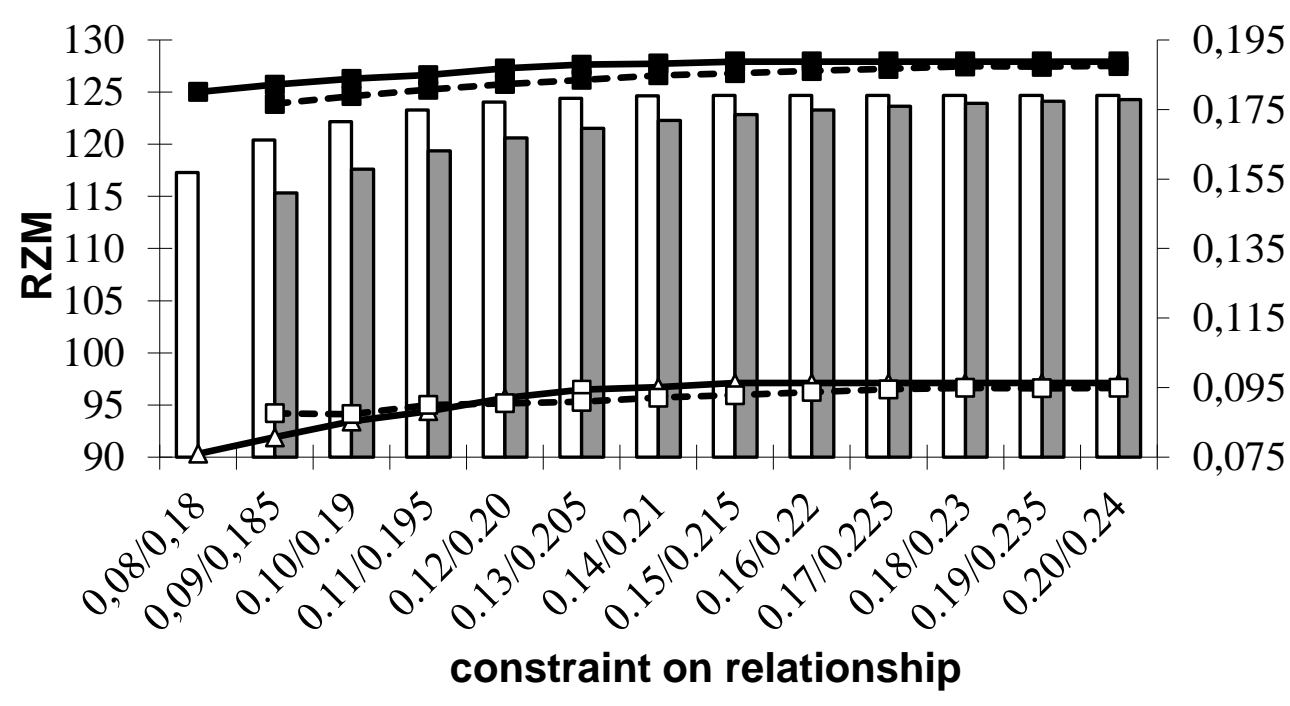

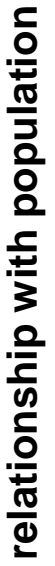

Figure 2. Average production index (INDEX-PROD) of selected bull sires and bull dams and their average relationship at different constraints for additive genetic and genomic relationships (white bars = average INDEX-PROD for constraint on additive genetic relationship; grey bars = average INDEX-PROD for constraint on genomic relationship; solid lines $=$ constraint on additive genetic relationships; dashed lines = constraint on genomic relationships; lines with white squares = realized additive genetic relationships; lines with black squares $=$ realized genomic relationships). 


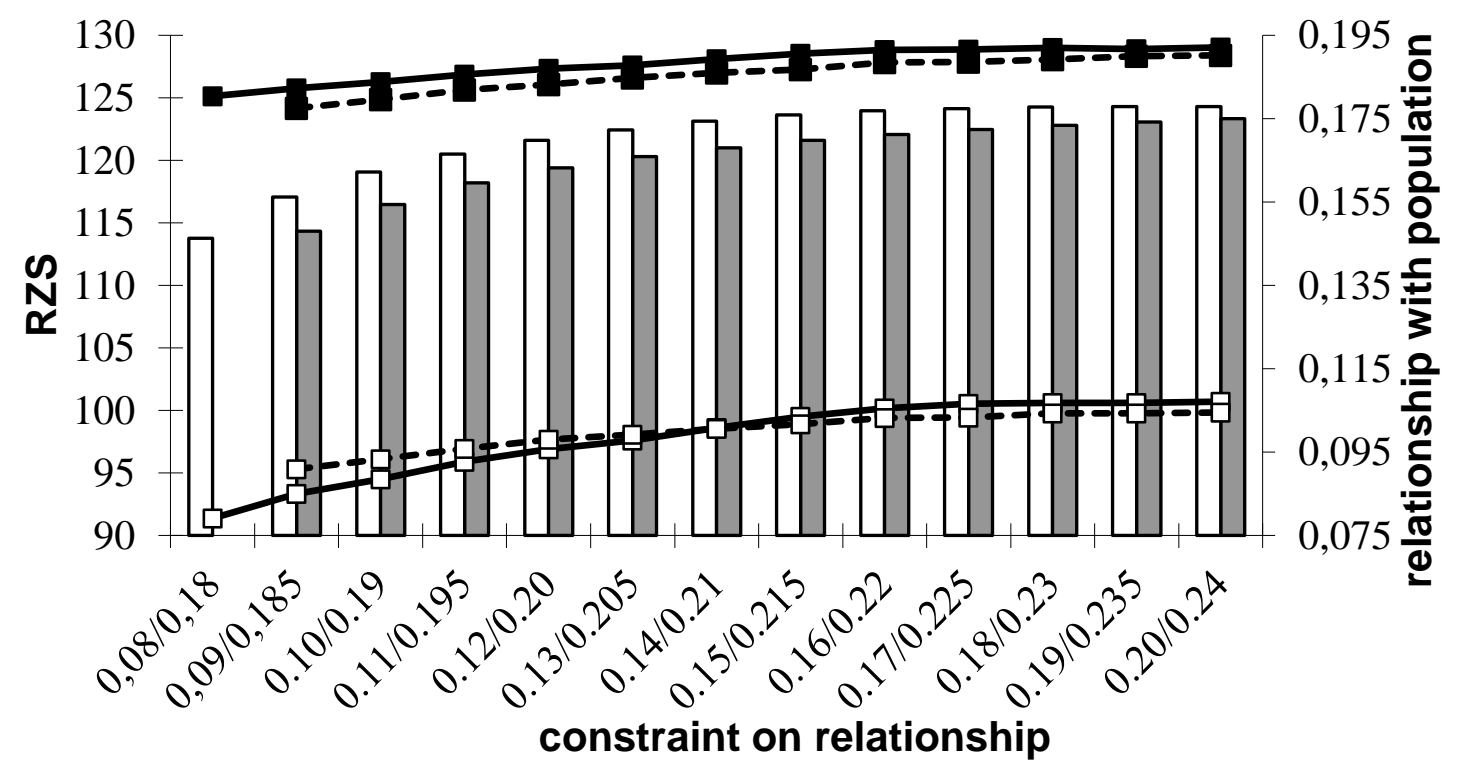

Figure 3. Average somatic cell score index (INDEX-SCS) of selected bull sires and bull dams and their average relationship at different constraints for additive genetic and genomic relationships (white bars = average INDEX-SCS for constraint on additive genetic relationship; grey bars = average INDEX-SCS for constraint on genomic relationship; solid lines $=$ constraint on additive genetic relationships; dashed lines = constraint on genomic relationships; lines with white squares = realized additive genetic relationships; lines with black squares $=$ realized genomic relationships).

When selection was constrained on additive genetic relationships, average INDEX-PROD and average INDEX-SCS of selected animals was maximal for an allowed restriction of $a_{i j}=0.15$ (Figure 2 and Figure 3). For constraints on genomic relationships, we observed a continuous increase in genetic gain over the whole range of constraints from $f_{i j}=0.185$ to $f_{i j}=0.24$. The average value of INDEX-PROD was generally lower when selection was restricted on genomic relationships. This finding is in line with results from a comprehensive simulation study for aquaculture species conducted by Sonesson et al. (2010). In their study, genetic gain was $37-60 \%$ higher when constraining the increase in inbreeding based on pedigree data compared to constraints in inbreeding based on genomic data. No optimum solution was found for a constraint of $f_{i j}=0.18$ on genomic relationships, when the minimum contribution of an individual sire was set to $2 \%$. 
For severe constraints on genomic relationships, i.e. in the range from $f_{i j}=$ 0.185 to $f_{i j}=0.195$, solutions for additive genetic relationships were more relaxed compared to corresponding restrictions of pedigree relationships (Figure 2 and Figure 3; comparison of lines with white squares). When increasing the allowed relationships from $f_{i j}=0.20$ to $f_{i j}=0.24$, solutions for coefficients of additive genetic relationships were higher compared to corresponding restrictions on additive genetic relationships (i.e. altering $a_{i j}=$ 0.12 to $\left.a_{i j}=0.20\right)$. This was found by Sonesson et al. (2010) for all analyzed scenarios. However, differences in solutions for additive genetic relationships were marginal, probably random, but interesting in its observed trend.

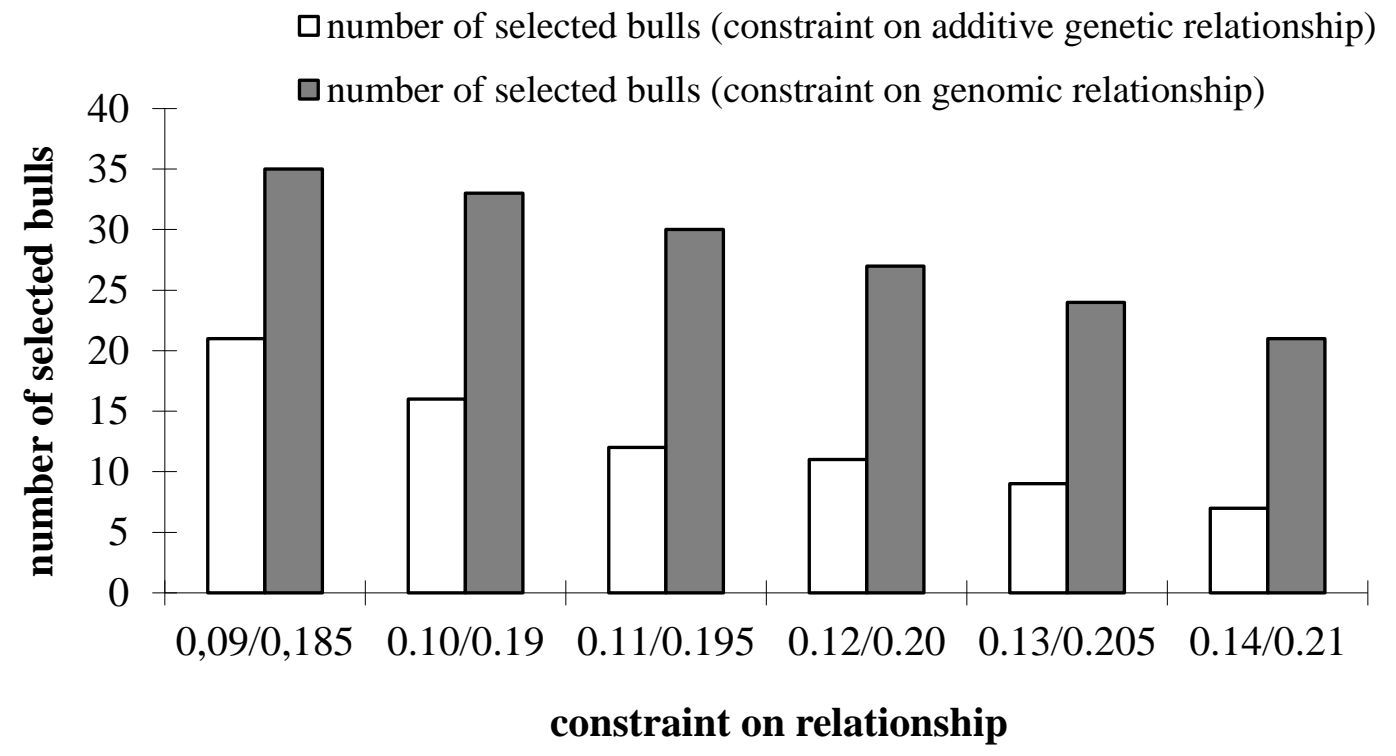

Figure 4. Number of selected bull sires at different constraints on average additive genetic and genomic relationships (selection criteria: INDEX-PROD) 


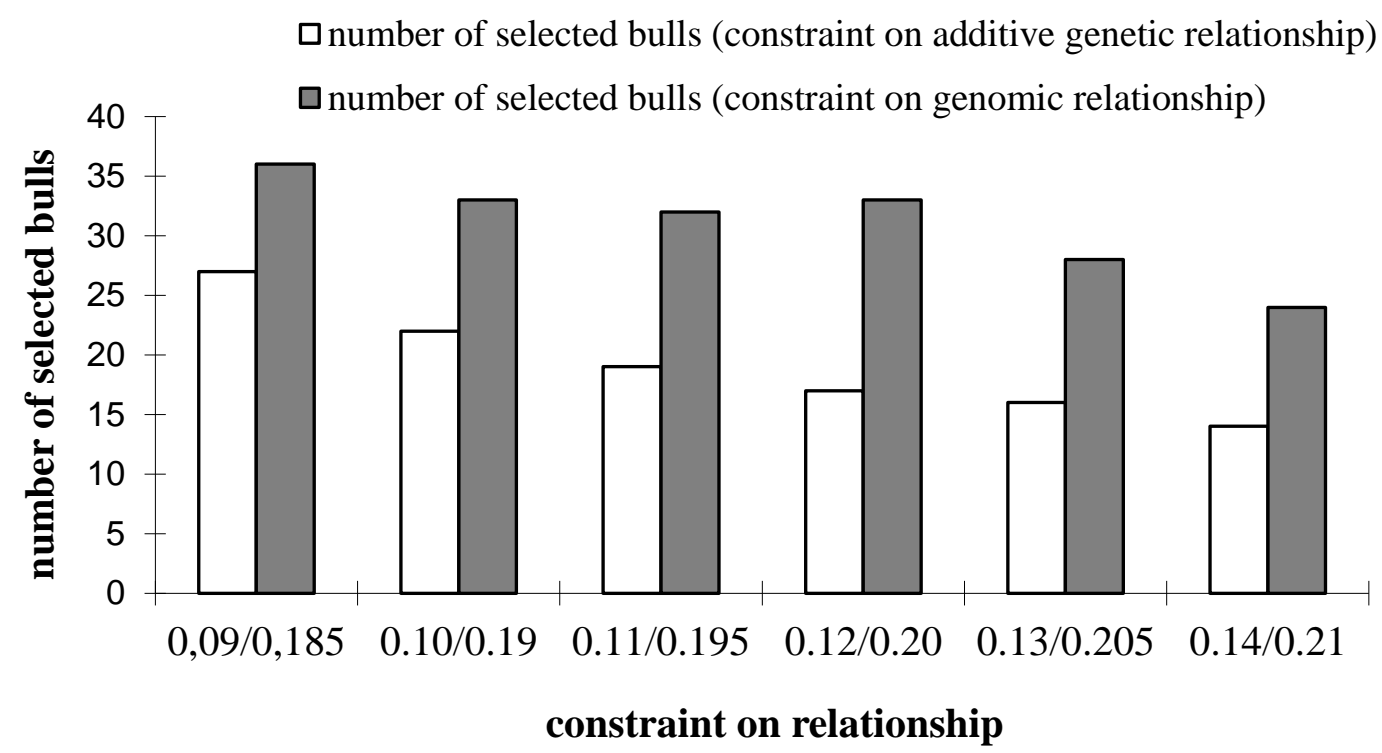

Figure 5. Number of selected bull sires at different constraints on average additive genetic and genomic relationships (selection criteria: INDEX-SCS)

According to Sonesson et al. (2010), solutions for realized genomic relationships were generally lower when restricting selection on genomic relationships compared to restrictions on pedigree relationships (Figure 2 and Figure 3, comparison of black squares). As expected, a target orientated restriction produced more desired results. This desired advantage, i.e. substantially lower solutions for average genomic relationships, decreased with an increase in allowed restrictions. The same trends for solutions in terms of genetic gain and realized relationships were observed for the high heritability trait (INDEX-PROD, Figure 2), and the low heritability trait (INDEX-SCS, Figure 3). Although more bulls were selected in the INDEXSCS than in the INDEX-PROD scenario (comparison of results in Figure 4 and Figure 5), realized relationships were marginally higher for INDEX-SCS scenarios, maybe due to the lower SD in INDEX-SCS for bull sires.

Associations between genetic contributions of selected sires and their indices (INDEX-PROD, INDEX-SCS) for four different constraints on relationships are depicted in Figure 6 and in Figure 7. Differences in genetic contributions among selected sires increased with a relaxing constraint on coefficients of relationships, which is in line with previous studies (e.g. Kearney et al., 
2004). In our study and in contrast to results by Kearney et al. (2004) and by König and Simianer (2006), selected sires with the highest EBV always had the highest genetic contributions. This was probably a coincidence as those animals had relatively low coefficients of relationship. For example, the four best sires for INDEX-PROD had an average additive genetic relationship with the population of $a_{i j}=0.089$, and a genomic relationship of $f_{i j}=0.183$. Generally, a wider range for INDEX-PROD (Figure 6) and INDEX-SCS (Figure 7) of selected sires was found when constraining genomic relationships.

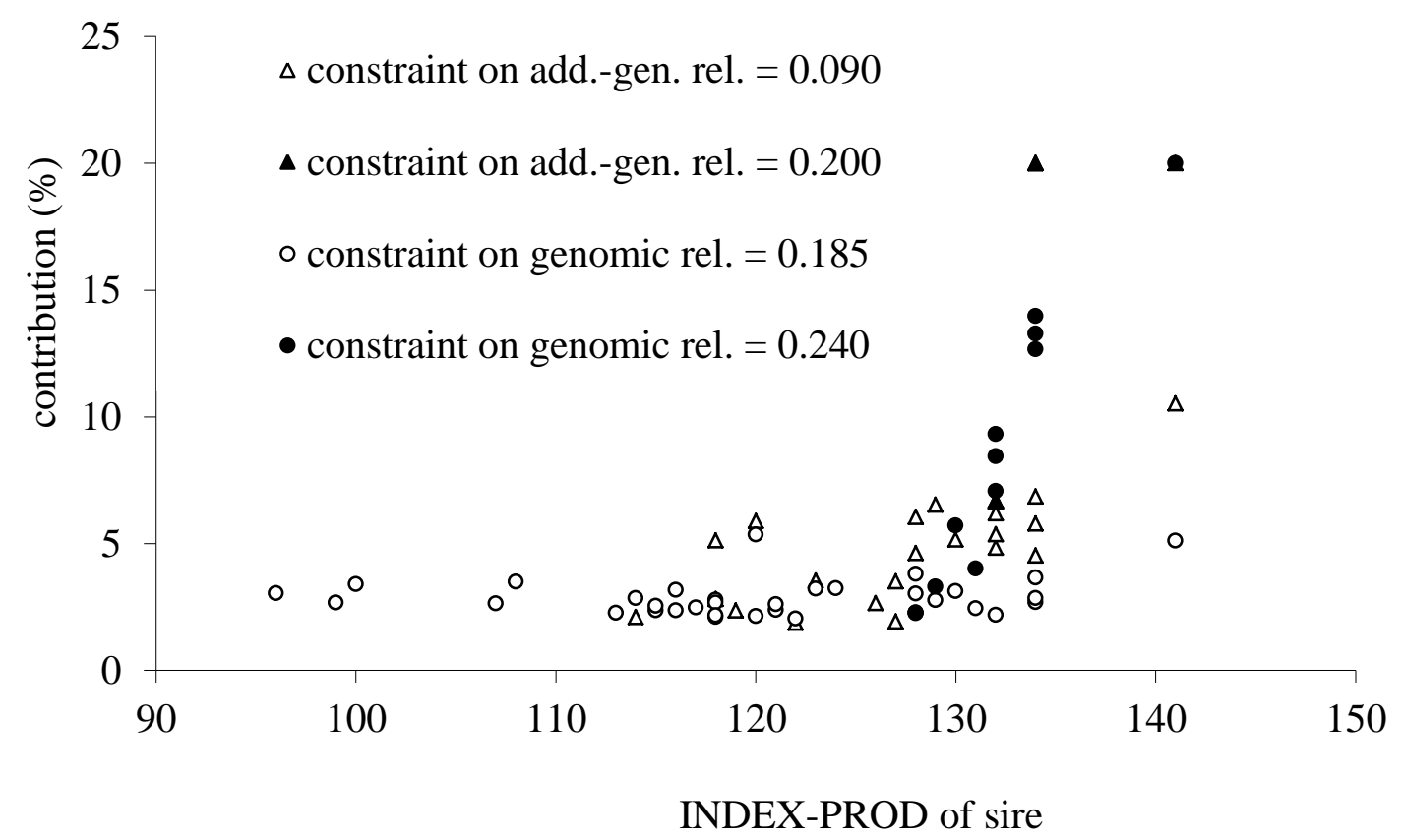

Figure 6. Association between optimized genetic contributions of bull sires and their production index (INDEX-PROD) for two levels of constraint on average additive genetic (constraint on add.-gen. rel.) and genomic relationship (constraint on genomic rel.). 


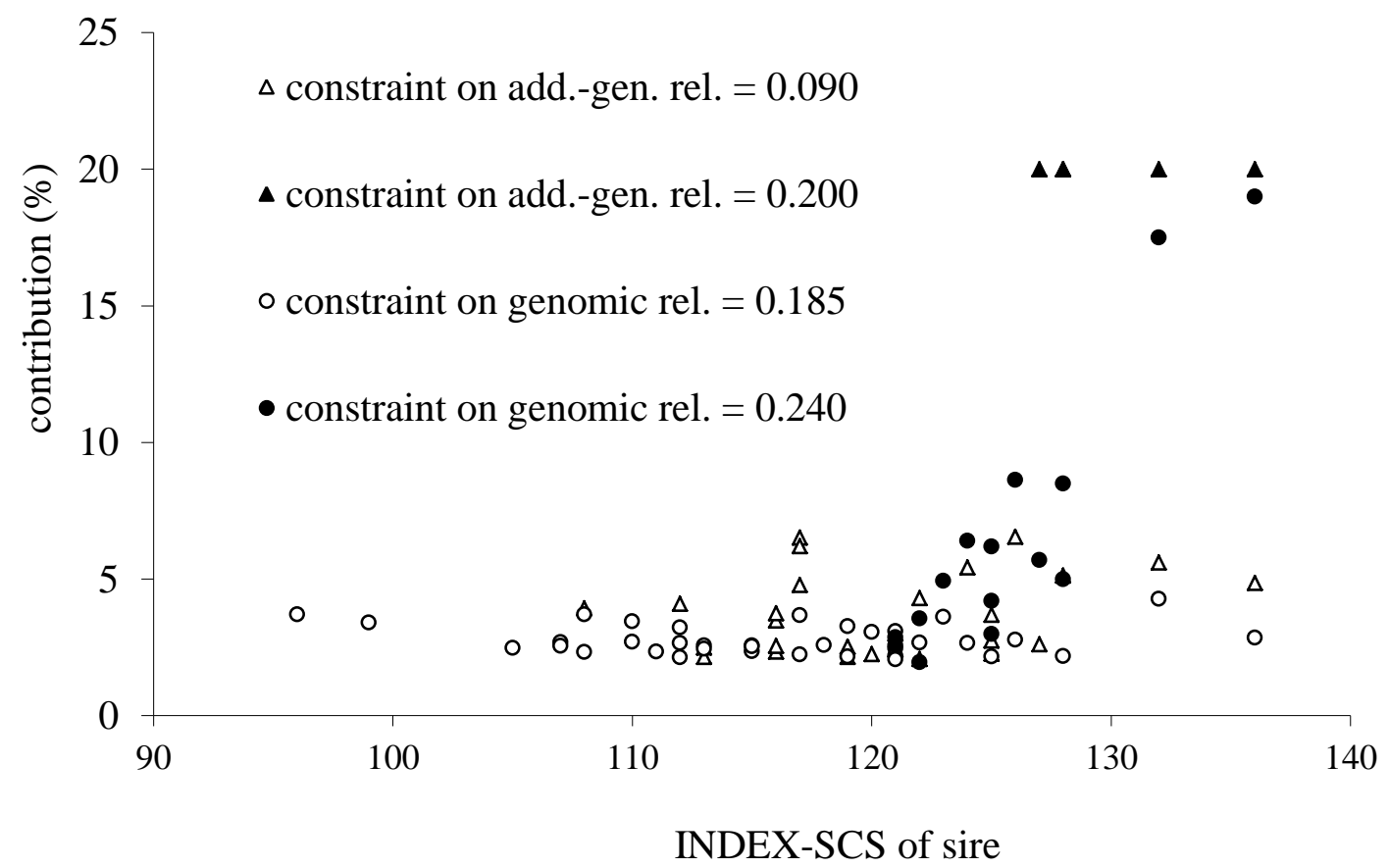

Figure 7. Association between optimized genetic contributions of bull sires and their somatic cell score index (INDEX-SCS) for two levels of constraint on average additive genetic (constraint on add.-gen. rel.) and genomic relationship (constraint on genomic rel.).

\section{Specific mating designs}

Average relationships of mating partners when combining results from the SDP algorithm with simulated annealing are shown in Figure 8 and Figure 9 for INDEX-PROD and INDEX-SCS, respectively. Following these results, a further reduction of coefficients for genomic and pedigree relationships is possible when only focussing on the minimization of relationships or inbreeding coefficients of individuals in the following generation by using an annealing algorithm as proposed by Sonesson and Meuwissen (2000). For example, with selection based on INDEX-PROD and restricting the maximal additive genetic relationship to a value of $a_{i j}=0.09$, all possible sire-dam pairs suggested by the SDP algorithm had an average additive genetic relationship of $a_{i j}=0.068$, and an average genomic relationship of $f_{i j}=0.179$. Matings proposed by the annealing algorithm had an average additive 
genetic relationship of $a_{i j}=0.048$, and an average genomic relationship of $f_{i j}$ $=0.164$. A comparable scenario using SDP with a constraint on genomic relationship at $f_{i j}=0.185$ led to an average additive genetic relationship of all possible sire-dam pairs of $a_{i j}=0.078$, and an average genomic relationship of $f_{i j}=0.165$. The average additive genetic relationship was $a_{i j}=0.06$, and average genomic relationship was $f_{i j}=0.135$ when subsequently applying the simulated annealing algorithm.

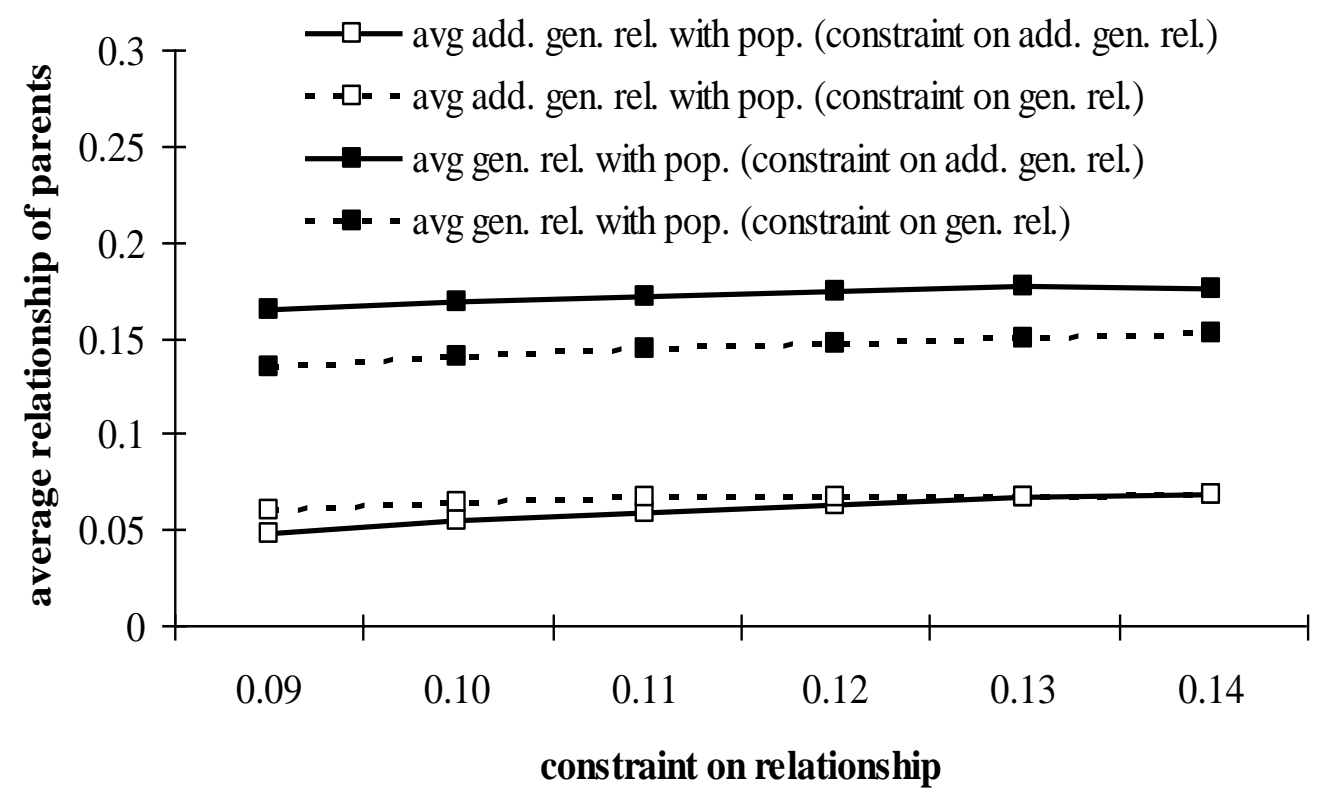

Figure 8. Average relationships of parents of the next generation when specifying matings with an annealing algorithm at different constraints for average additive genetic and genomic relationships (selection criteria: INDEX-PROD; solid lines = constraint on additive genetic relationships; dashed lines = constraint on genomic relationships; lines with white squares $=$ realized additive genetic relationships; lines with black squares = realized genomic relationships) 


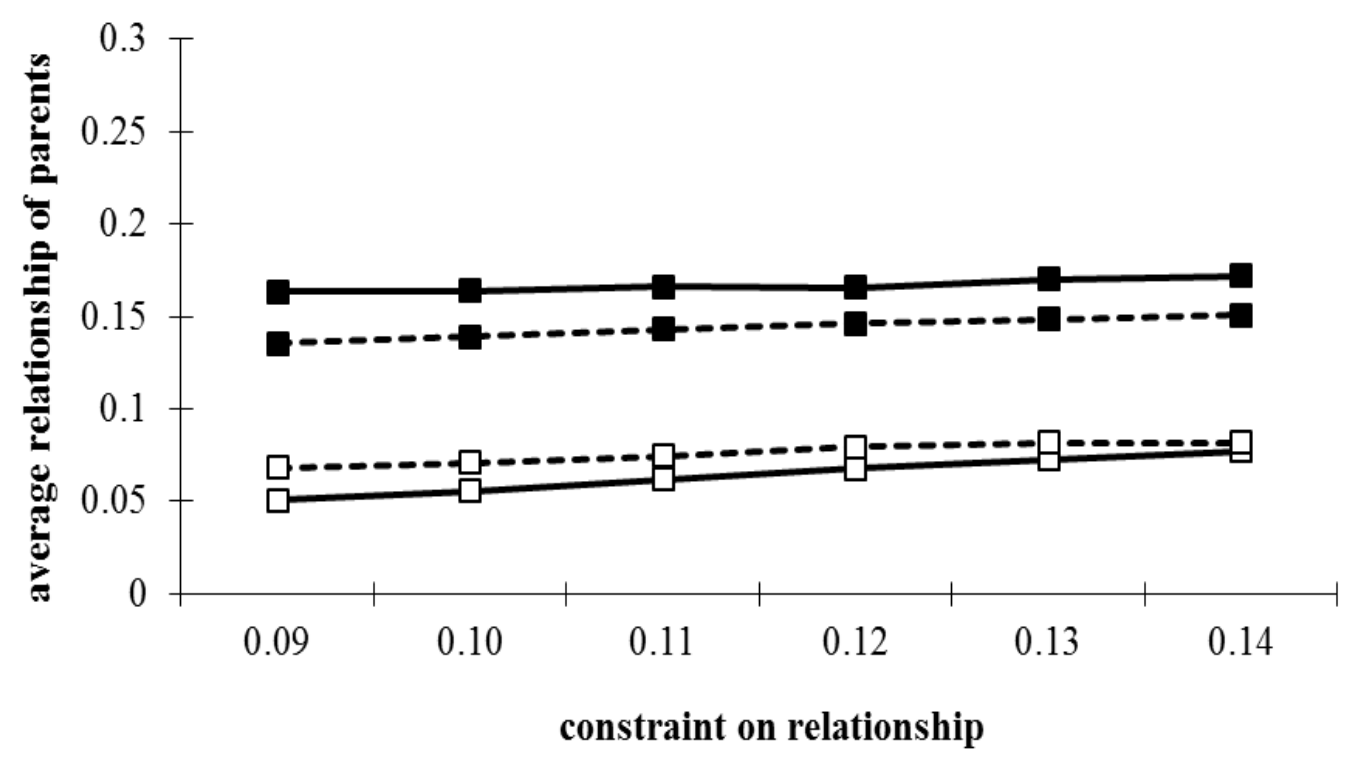

Figure 9. Average relationships of parents of the next generation when specifying matings with an annealing algorithm at different constraints for average additive genetic and genomic relationships (selection criteria: INDEX-SCS; solid lines = constraint on additive genetic relationships; dashed lines $=$ constraint on genomic relationships; lines with white squares $=$ realized additive genetic relationships; lines with black squares $=$ realized genomic relationships)

The results from the simulated annealing algorithm were also in agreement with calculations conducted in another region of Germany for Holstein dairy cattle (König and Simianer, 2006). As one specific example from this study, 21 selected bulls and 30 selected cows were mated at random. The expected inbreeding coefficient for their progeny was $1.38 \%$. In contrast, the simulated annealing algorithm suggested a mating plan with an average inbreeding coefficient in the next generation of only $0.46 \%$.

Again, the mating design from the simulated annealing algorithm can be considered as a strategy for avoiding or minimizing inbreeding in the short term. Such a strategy could make sense for species or breeding plans characterized by long generation intervals, especially in dairy cattle or horse breeding programs (Niemann et al., 2009). For species with short generation intervals, e.g. pig or poultry breeding, the advantage from minimizing inbreeding in the short term will erode very quickly (König et al., 2010). But 
also competitive future genomic dairy cattle breeding programs will be characterized by a substantial shortening in generation intervals, especially on the bull sire and cow sire pathway of selection (Schaeffer et al., 2006). From this point of view, the general OGC concept without the application of specific mating plans should be the major motivation.

\section{General perspective}

Daetwyler et al. (2007) pointed out that genomic selection will lead to lower inbreeding than traditional selection schemes, because the accuracies of estimated Mendelian sampling terms will be higher. This allows a higher differentiation within families, and a lower probability of co-selection of sibs. From the practical point of view (König et al., 2009; Hayes et al. 2009), a shorter generation interval in combination with high accuracies of GEBVs for young sires may lead to higher rates of inbreeding. Therefore, methods for optimizing long term genetic contributions as presented in this study are of major importance to avoid a future increase in inbreeding. Selection on bull sires and bull dams, as well as selection of cow sires is controlled by breeding organizations. Hence, the OGC concept as an additional so called 'controlling instrument' could easily be implemented in this step of selection (König et al., 2007).

Most of the trends in terms of genetic gain or realized relationships in our study were similar when comparing results from restrictions on pedigree or on genomic relationships, but minor differences could be of practical importance. Consequently, the more sophisticated and innovative approach is based on marker data and should be applied for scientific objectives as suggested by Pimentel et al. (2011b).

We applied the OGC concept for the selection of bull sires and bull dams within a framework of a genomic breeding program as suggested by Schaeffer (2006), and by König et al. (2009). The genomic era further allows for a change from the four-pathway selection strategy in dairy cattle as introduced by Rendel and Robertson (1950) to a two-pathway selection strategy (König and Swalve, 2009). Such a strategy implies that a multitude of male calves, being all selection candidates for $\mathrm{Al}$, are genotyped. This would erode the traditional concept of mating designs and selection 
strategies for bull sires and bull dams. Hence, further improvements for maximizing genetic gain and minimizing relationships should focus on SNPpatterns of male calves, e.g. the construction of a heterozygosity index. Our approach should be considered as a breeding tool in the transitional phase from the conventional towards the genomic era. However, we also assume that some form of pre-selection in terms of elite matings may still exist, and already at this early step of selection, minimizing relationships will contribute to ensure long term selection response. Without pre-selection, the proposed method might be challenging for extremely large datasets, but as stated by Sonesson et al. (2011), using genomic relationships will result in a more precise control of the genomic inbreeding.

\section{Conclusion}

Due to the continuous increase of inbreeding, the accumulation of defect genes, and the risk of inbreeding depressions, Holstein dairy cattle breeding programs should consider both aspects maximizing genetic gain and minimizing long term genetic relationships. In contrast to previous applications using GENCONT software and pedigree based relationships, we focused on semi-definite programming and relationships constructed from SNP data. For moderately as well as for lowly heritable traits, our approach can identify those mating partners that ensure a maximum genetic gain at specific constraints on maximum relationship. Our approach has been suggested to identify elite matings between pre-selected bull sires and bull dams using SNP data, but the flexibility of this concept, i.e. the combination of pedigree based and marker data, allows an application for a broad variety of aspects to maintain genetic diversity (e.g. Wang, 2001).

\section{Acknowledgements}

The authors appreciate funding from the Lower Saxon Ministry of Food, Agriculture, Consumer Protection and Regional Development. Parts of this study were also conducted within the projects FUGATO-plus brain and FUGATO-plus GenoTrack which were financially supported by the German Ministry of Education and Research. Furthermore assistance from Dr. 
Ricardo Pong-Wong during the configuration of the semi-definite programming algorithm is kindly appreciated.

\section{References}

Daetwyler, H.D., B. Villanueva, P. Bijma, and J.A. Woolliams. 2007. Inbreeding in genome-wide selection. J.Anim. Breed. Genet. 124:369-376.

Eding, H., and T.H.E. Meuwissen. 2001. Marker-based estimates of between and within population kinships for the conservation of genetic diversity. J. Anim. Breed. Genet. 118:141-159.

Emik, L.O., and C.R. Terrill. 1949. Systematic procedures for calculating inbreeding coefficients. J. Hered. 40:41-55

Fujisawa, K., M. Kojima, K. Nakata, M. Yamashita. 2002. SDPA (SemiDefinite Programming Algorithm) user's manual - version 6.00. Research Reports on Mathematical and Computer Sciences, Series B: Operations Research.

Gengler, N., P. Mayeres, and M. Szydlowski. 2007. A simple method to approximate gene content in large pedigree populations: application to the myostatin gene in dual-purpose

Belgian Blue cattle. Animal 1:21-28.

Hayes, B.J., P.J. Bowman, A.J. Chamberlain, and M.E. Goddard. 2009. Invited review: Genomic selection in dairy cattle: Progress and challenges. J. Dairy Sci. 92:433-443.

Kearney, J.F., E. Wall, B. Villanueva, M.P. Coffey. 2004. Inbreeding trends and application of optimized selection in the UK Holstein Population. J. Dairy Sci. 2004 87:3503-3509.

König, S., and H. Simianer. 2006. Approaches to the management of inbreeding and relationship in the German Holstein dairy cattle population. Livest. Sci. 103: 40-53.

König, S., S. Lessner, and H. Simianer. 2007. Application of controlling instruments for improvements in cow sire selection. J. Dairy Sci. 90:19671980.

König, S., Simianer, H. and A.Willam. 2009. Economic evaluation of genomic breeding programs. J. Dairy Sci. 92:382-391. 
König, S., F. Tsehay, F. Sitzenstock, U.U. v. Borstel, M. Schmutz, R. Preisinger, and H. Simianer. 2010. Evaluation of Inbreeding in Laying Hens by applying Optimum Genetic Contribution and Gene Flow Theory. Poultry Sci. 89:658-667.

König, S., and H.H. Swalve. 2009. Application of selection index calculations to determine selection strategies in genomic breeding programs. J. Dairy Sci. 92:5292-5303.

Meuwissen, T.H.E. 1997. Maximizing the response of selection with a predefined rate of inbreeding. J. Anim. Sci. 75:934-940.

Meuwissen, T.H.E. 2002. GENCONT: An operational tool for controlling inbreeding in selection and conservation schemes. $7^{\text {th }}$ World Congress on Genetics Applied to Livestock Production. Proc. $7^{\text {th }}$ Wld. Congr. Genet. Appl. Livest. Prod., Montpellier, France, August 19-23. CD-ROM communication no. 28:20.

Miglior, F. 2000. Impact of inbreeding - Managing a declining Holstein pool. Proc. $10^{\text {th }}$ World Holstein Friesian conference, Sydney, Australia:108-113. Mrode, R., J.F. Kearney, S. Biffani, M. Coffey, and F. Canavesi. 2009. Short communication: Genetic relationships between the Holstein cow populations of three European dairy countries. J. Dairy Sci. 92:5760-5764.

Niemann, B., S. König, and E. Bruns. 2009. Maximizing genetic gain by restricting inbreeding in Hanoveranian breeding programme for show jumpers. Züchtungskunde 81:51-57.

Pimentel, E.C.G., M. Erbe, S. König, and H. Simianer. 2011a. Genome partitioning of genetic variation for milk production and composition traits in Holstein cattle. Front. Gene. 2:19.

Pimentel, E.C.G., S. Bauersachs, M. Tietze, H. Simianer, J. Tetens, G. Thaller, F. Reinhardt, E. Wolf, and S. König. 2011b. Exploration of relationships between production and fertility traits in dairy cattle via association studies of SNPs within candidate genes derived by expression profiling. Anim. Genetics 42:251-262.

Pong-Wong, R., and J.A. Woolliams. 2007. Optimisation of contribution of candidate parents to maximise genetic gain and restricting inbreeding using semidefinite programming. Genet. Sel. Evol. 39:3-25. 
Press, W.H., B.P. Flannery, S.A. Teukolsky, W.T. Vetterling, Minimization or maximization of functions, in: Numerical recipes - The art of scientific computing. University of Cambridge Press, 1989, pp. 274_334.

Rendel, J.M., and A. Robertson. 1950. Estimation of genetic gain in milk yield by selection in a closed herd of dairy cattle. J. Genetics 50:1-8.

Sanders, K., J. Bennewitz, and E. Kalm. 2006. Wrong and missing sire information affects genetic gain in the Angeln dairy cattle population. J. Dairy Sci. 89: 315-321.

Schaeffer, L.R. 2006. Strategy for applying genome-wide selection in dairy cattle. J. Anim. Breed. Genet. 123: 218-223.

Schork, N.J. 2001. Genome partitioning and whole-genome analysis. Advances in Genetics 42: 299-322.

Sonesson, A.K., and H.E Meuwissen. 2000. Mating schemes for optimum contribution selection with constrained rates of inbreeding. Genet. Sel. Evol. 32:231-248.

Sonesson, A.K., J.A. Woolliams, and T.H.E. Meuwissen. 2010. Maximising genetic gain whilst controlling rates of genomic inbreeding using genomic optimum contribution selection. Proc. $9^{\text {th }}$ Wld. Congr. Genet. Appl. Livest. Prod., Leipzig, Germany, August 1 - 6, Abstract no. 892.

Thompson, J.R., R.W. Everett, C.W. Wolfe. 2000. Effects of inbreeding on production and survival in Jerseys. J. Dairy Sci. 83:2131-2138.

VanRaden, P.M. 2005. Inbreeding adjustments and effect on genetic trend estimates. Interbull Bulletin 33:81-84.

VanRaden, P.M., C.P. Van Tassel, G.R. Wiggans, T.S. Sonstegard, R.D. Schnabel, J.F. Taylor, and F.S. Schenkel. 2009. Invited Review: Reliability of genomic predictions for North American Holstein bulls. J. Dairy Sci. 92:16-24.

Wang, J. 2001. Optimal marker-assisted selection to increase the effective size of small populations. Genetics 157:867-874.

Weigel, K.A. and S.W. Lin. 2002. Controlling Inbreeding by Constraining the Average Relationship Between Parents of Young Bulls Entering AI Progeny Test Programs. J. Dairy Sci. 85:2376-2383. 
Weller, J.I., E. Feldmesser, M. Golik, I. Tager-Cohen, R. Domochowsky, O. Alus, E. Ezra, and M. Ron. 2004. Factors affecting incorrect paternity assignment in the Israeli Holstein population. J. Dairy Sci. 73:2627-2640.

Wensch-Dorendorf, M., T. Yin, H.H. Swalve, and S. König. 2011. Optimal strategies for the use of genomic selection in dairy cattle breeding programs. J. Dairy Sci. doi:10.3168/jds.2010-4101.

Wiggans, G. R., P.M. Van Raden, J. Zuurbier. 1995. Calculation and use of inbreeding coefficients for genetic evaluation of United States dairy cattle. J. Dairy Sci. 78:1585-1590.

Wright, S. 1922. Coefficients of inbreeding and relationship. Am. Nat. 56:330-338. 


\section{Lebenslauf}

\section{Persönliche Daten}

geb. am 23.07.1979

Geburtsort: Bremen

verheiratet

\section{Berufstätigkeit}

seit $05 / 2010$

wissenschaftlicher Mitarbeiter bei vit, w.V., Verden

$09 / 2006-09.2009$

wissenschaftlicher Mitarbeiter

an der Georg-August-Universität Göttingen, Department für Nutztierwissenschaften, Abteilung Tierzucht und Haustiergenetik

\section{Studium und Ausbildung}

09/2006-06/2010

$04 / 2005-05 / 2006$

$10 / 2001-03 / 2005$

$08 / 1999-07 / 2000$

08/2000-07/2001

18.07.2001
Promotionsstudium im Fach Agrarwissenschaften an der Georg-August-Universität Göttingen, Department für Nutztierwissenschaften, Abteilung Tierzucht und Haustiergenetik

Georg-August-Universität Göttingen, Masterstudiengang Agrarwissenschaften, Studienrichtung Tierproduktion

Georg-August-Universität Göttingen, Bachelorstudiengang Agrarwissenschaften, Studienrichtung Tierproduktion

Fiedler GbR, Ströhen, Ausbildung zum Landwirt Cord Schütte, Ganderkesee, Ausbildung zum Landwirt Abschluss: Landwirt

\section{Schule}

